KRZYSZTOF R. PROKOP - GLIWICE

\title{
BLOGOSLAWIONY ARCYBISKUP RADZIM-GAUDENTY I ZAGADNIENIE POCZĄTKÓW METROPOLII GNIEŹNIEŃSKIEJ W HISTORIOGRAFII STAROPOLSKIEJ ${ }^{1}$
}

I.

Dzieje Polski pierwszych Piastów, niewątpliwie obfitujące w wiele doniosłej rangi wydarzeń, znajdują odzwierciedlenie w bardzo nielicznych współczesnych źródłach, odznaczających się też zazwyczaj lapidarnością przekazu. To sprawia, że o niejednym istotnym fakcie z tamtego czasu wiemy niewiele, albo zgoła nic, a w konsekwencji kreślony przez żyjących w wiele wieków później historiografów i badaczy obraz tamtej epoki jest dalece fragmentaryczny, niekiedy nawet niespójny, na to zaś jeszcze nakładają się w pojedynczych przypadkach ocierające się zgoła o fantazję hipotezy niektórych autorów, pragnących za wszelką cenę

\footnotetext{
${ }^{1}$ Przedkładany uwadze czytelnika tekst powstał w roku 2006, z przeznaczeniem do publikacji w ramach zapowiadanej edycji materiałów sesji naukowej U początków polskiej organizacji kościelnej i państwowej, która obradowała w dniu 5 X 2006 r. w Gnieźnie. W związku z faktem, że organizatorzy sesji ostatecznie jednak zrezygnowali z wydania drukiem jej naukowego pokłosia, został on złożony do druku w Studiach Lednickich i miał ukazać się w tomie dziesiątym tego periodyku (za rok 2010). Ujawniona dopiero na etapie opracowania redakcyjnego oraz korekty, a warunkowana odgórnie przyjętymi dla owej serii regułami wydawniczymi, konieczność zmiany sposobu prezentacji aparatu naukowego na tak zwany oksfordzki system przypisów, w tym konkretnym przypadku nie służący przejrzystości opracowania, skłoniła autora - mimo podpisania już do druku odnośnego tomu „Studiów Lednickich” - do wycofania tekstu i przeniesienia go na inne łamy. Tekst ukazuje się zatem dopiero po pięciu latach od momentu powstania i nie nie uwzględniono w nim tytułów, które wydane zostały drukiem po roku 2006.
} 
udzielić odpowiedzi na pytania, które najprawdopodobniej na zawsze pozostaną nieodgadnionymi. Nie inaczej rzecz przedstawia się w odniesieniu do żyjących $\mathrm{w}$ tamtych momentach dziejowych postaci, których curriculum vitae składa się często z ledwie kilku niepowiązanych bezpośrednio ze sobą faktów, a do tego brak nawet tak fundamentalnego punktu odniesienia w kreśleniu biografii, jak data śmierci (o urodzeniu nie wspominając). Mogło by się tedy wydawać uprawnionym przypuszczenie, że tego rodzaju niemożliwe do pokonania przeszkody przy próbie ewentualnego dociekania genezy, okoliczności i skutków znanego z pojedynczej zapiski wydarzenia, podobnie jak i przy rekonstruowaniu życiorysów postaci z owych zamierzchłych czasów, winny skutecznie zniechęcać późniejszych historiografów i badaczy do sięgania po tak niewdzięczną tematykę. Rzeczywistość okazuje się jednak dalece odmienna, jako że do dziejów Polski w X, XI i XII stuleciu dysponujemy bardzo obfitą literaturą przedmiotu, która też z upływem kolejnych dekad stale się powiększa. W szczególny sposób przyczyniają się do tego rozmaite okrągłe rocznice, żeby wspomnieć w tym kontekście przede wszystkim o tysiącleciu chrztu Mieszka I sprzed czterech dziesięcioleci (1966), czy świeżej jeszcze daty milenium utworzenia stałej organizacji diecezjalnej na ziemiach polskich i powstania metropolii gnieźnieńskiej $(1999 / 2000)^{2}$. Po tych nadzwyczaj podniosłych jubileuszach, celebrowanych stosownie do ich rangi, przyszedł czas na uczczenie tysięcznej rocznicy śmierci pierwszego arcybiskupa Gniezna - bł. Radzima-Gaudentego. Trudno oczekiwać, by obchodom także tego milenium nadano podobnie spektakularną oprawę, co dwóm wcześniej wspomnianym, jako że z jednej strony mamy do czynienia z wydarzeniem, którego konsekwencje dla dalszych dziejów ojczystych, w tym nawet dla losów chrześcijaństwa w Polsce, nie były choćby w części równie doniosłe, co w przypadku tamtych, z drugiej zaś brak nam de facto pewności, że owa tysięczna rocznica zgonu hierarchy, zapoczątkowującego poczet metropolitów gnieźnieńskich, przypada właśnie na rok 2006.

Nie stanowi naszego zamiaru rozwodzić się w tym miejscu w przedmiocie kontrowersji związanych z datą śmierci bł. Radzima-Gaudentego, nie taka jest bowiem tematyka obecnego opracowania. Pozostawiając ewentualne podjęcie na nowo tego wątku (nie raz już wszak poruszanego przez badaczy) innym autorom, poprzestaniemy na stwierdzeniu, iż rzeczą bez wątpienia ze wszech miar zasadną i pożądaną jest przypomnienie osobom żyjącym u progu XXI stulecia tak ważnej dla dziejów Kościoła i państwa polskiego postaci sprzed dziesięciu wieków ${ }^{3}$, stąd dobór okazji po temu można traktować jako zagadnienie zgoła drugorzędne. Wspomnijmy w tym kontekście dla porównania, iż jakkolwiek 650-lecie utworzenia stolicy metropolitalnej w Pradze minęło jeszcze w roku 1994, gdy z kolei

${ }^{2}$ Zob. J. Strzelczyk, Naukowe pokłosie milenium zjazdu gnieźnieńskiego, „Roczniki Historyczne”, 68 (2000) s. 157-174; również G. Labuda, O badaniach nad zjazdem gnieźnieńskim roku 1000 - spostrzeżenia i zastrzeżenia, „Roczniki Histo-ryczne”, 68 (2000) s. 107-156; J. Strzelczyk, Naukowe pokłosie milenium śmierci św. Wojciecha, „Nasza Przeszłość”, 98 (2002) s. 5-97.

${ }^{3}$ Por. „L'Osservatore Romano” [edycja polska] 27 (2006) nr 11 (287), s. 59 (telegram papieża Benedykta XVI z okazji tysięcznej rocznicy śmierci bł. Radzima-Gaudentego: Watykan, 24 VI 2006 r.). 
650. rocznica śmierci pierwszego arcybiskupa praskiego Arnošta z Pardubic przypada dopiero w roku 2014, to jednak ostatnimi czasy jesteśmy świadkami ukazywania się drukiem, pomiędzy tymi dwoma datami, kolejnych publikacji związanych z owymi jubileuszami ${ }^{4}$. Bez względu zatem, czy bł. Radzim-Gaudenty zmarł w roku 1006, 1011, 1016 (żeby wyliczyć te najczęściej podawanego w jego życiorysach), czy innym jeszcze, owa tak czy inaczej chronologiczna bliskość milenium zgonu pierwszego metropolity Gniezna stwarza dogodną sposobność, by skoncentrować naszą uwagę na postaci wprawdzie z zamierzchłej przeszłości, której znaczenia w rodzimych dziejach nie sposób jednak nie doceniać.

W obecnym opracowaniu zamierzamy wskazać - z konieczności w sposób do pewnego stopnia skrótowy - na obecność bł. Radzima-Gaudentego w historiografii staropolskiej. Terminem „historiografia” posługujemy się tu zasadniczo w jego węższym rozumieniu, mając na uwadze piśmiennictwo historyczne świadomie dążące do krytycznego oglądu przeszłości poprzez poddanie informacji zawartych w dostępnym materiale źródłowych oraz wcześniej powstałych dziełach interpretacji i weryfikacji - stosownie do poziomu i stopnia zaawansowania krytyki historycznej właściwej danej epoce. Tak też za pierwszego na gruncie polskim dziejopisarza, czyniącego w istotnej mierze zadość tego rodzaju oczekiwaniom, zwykło się uważać żyjącego w latach 1415-1480 Jana Długosza. Nie oznacza to bynajmniej, że wszyscy ci, którzy już po nim sięgali po pióro w zamiarze opisywania ojczystej przeszłości, czynili to w sposób zasługujący na uznanie tudzież poważne potraktowanie ich wywodów. Autorzy odznaczający się z jednej strony brakiem zmysłu krytycznego, z drugiej zaś obdarzeni bogatą wyobraźnią, pozwalającą im obficiej zapełniać „,białe plamy” historii, trafiają się wszak i dzisiaj, choć przecież postęp badań - zwłaszcza w ciągu ostatnich dwóch stuleci - sprawił, że współcześnie o wiele łatwiej oddzielić narosłą w ciągu wieków warstwę legendarną od owego solidnego fundamentu źródłowego, który zresztą - co wyżej zaznaczono - jawi się dla wieków X i XI nadzwyczaj skromnym. W poniższym opracowaniu spróbujemy zatem prześledzić ów proces mieszania się w nowożytnym piśmiennictwie historiograficznym dawnej Polski wiadomości o bł. RadzimieGaudentym zaczerpniętych ze współczesnych źródeł z przekazami o charakterze czy to wprost legendarnym, czy też niewiadomego pochodzenia, które jednak dopomogły znacząco „ubogacić” (w ujemnym tego słowa rozumieniu) życiorys przyrodniego brata św. Wojciecha. Wiele też trudu kosztowało później oddzielenie jednych od drugich, choć w rozmaitych popularnych publikacjach niektóre z owych nie mających umocowania źródłowego elementów biografii pierwszego arcybiskupa-metropolity Gniezna można jeszcze dziś napotkać.

${ }^{4}$ M.in. Arnošt z Pardubic (1297-1364). Postać - środowisko - dziedzictwo, red. L. Bobkova, R. Gładkiewicz i P. Vorel, Wrocław-Praha-Pardubice 2005 [gdzie m.in. teksty historiograficzne Z. Beneša, Arnošt z Pardubic v české historiografii (s. 107-114) i M. Cetwińskiego, Arnošt z Pardubic w śląskiej tradycji historiograficznej (s. 115-123)]; Z. Szczepaniak, Arnošt z Pardubic, Kłodzko - Nowa Ruda 2004; F. Šebek, Arnošt z Pardubic, Kłodzko 2005; także J. Swastek, Założenie metropolii praskiej w 1344 roku i sprawa przynależności do niej diecezji wrocławskiej w XIV wieku, w: Między Lwowem a Wrocławiem, red. B. Roka i J. Maronia, Toruń 2006, s. 61-69. 
II.

Zasób źródeł z samego końca X stulecia oraz XI-wiecznych, stanowiących ów najbardziej wiarogodny fundament przy kreśleniu curriculum vitae bł. Radzima-Gaudentego, jest od dawna znany i nie ulega zmianom, wszystkie też one zostały poddane gruntownej interpretacji, przy czym ostatnie słowo $\mathrm{w}$ tym względzie należy aktualnie do Gerarda Labudy ${ }^{5}$. Nie zachodzi zatem potrzeba ponownego ukazywania tu podstawy źródłowej, na której opiera się nasza wiedza o pierwszym arcybiskupie Gniezna ${ }^{6}$. Znamienna rzecz, że o hierarsze tym brak wzmianki w kontekście tzw. zjazdu gnieźnieńskiego czy też zaistnienia polskiej prowincji kościelnej w kronikach zarówno tzw. Galla Antonima, jak i mistrza Wincentego zwanego Kadłubkiem (obaj za to piszą o dwóch metropoliach za czasów Bolesława I Chrobrego), choć ów pierwszy wspomina go (i to z imienia) w zupełnie innym miejscu, gdzie mianowicie mowa jest o najeździe na Polskę księcia czeskiego Brzetysława I w roku 1038 („quae plaga creditur eo toti terrae communiter evenisse, quia Gaudentius, sancti Adalberti frater et successor, occassione qua nescio, dicitur eam anathemate percusisse") ${ }^{7}$. Ani słowem o Radzimie-Gaudentym nie wspomina się w najważniejszych zabytkach piśmiennictwa o charakterze narracyjnym z okresu dojrzałego średniowiecza polskiego, takich jak Kronika wielkopolska ${ }^{8}$, Kronika franciszkańska zwana Kronika Mierzwy ${ }^{9}$ czy

${ }^{5} \mathrm{Z}$ najnowszych publikacji tego badacza, w których o interesującej nas problematyce, zob. G. Labuda, Mieszko I, Wrocław-Warszawa-Kraków 2002, wg indeksu (Radzim-Gaudenty); G. Labuda, Święty Wojciech, biskup-męczennik, patron Polski, Czech i Wegier, Wrocław 2004², s. $227 \mathrm{nn}$.; G. Labuda, Droga życiowa Radzima-Gaudentego do arcybiskupstwa gnieźnieńskiego, w: O rzeczach minionych, red. M. Młynarska-Kaletynowa i J. Kruppé (Studia i Materiaty z Historii Kultury Materialnej, t. LXXI), Warszawa 2006, s. 179-190; G. Labuda, Zjazd i synod gnieźnieński roku 1000 w nowym oświetleniu historiograficznym, w: Cognitioni gestorum. Studia z dziejów średniowiecza, red. D.A. Sikorski i A.M. Wyrwa, Poznań - Warszawa 2006, s. 163-184.

${ }^{6}$ Zob. także: Hagiografia polska. Stownik bio-bibliograficzny, red. R. Gustaw, PoznańWarszawa-Lublin 1972, s. 260 (R. Gustaw); K. R. Prokop, Arcybiskupi gnieźnieńscy w tysiacleciu, Kraków 2000, s. 17-18 (w obu tych publikacjach wskazana wcześniejsza literatura). Por. nadto: A. Witkowska, J. Nastalska, Święty Wojciech-życie i kult. Bibliografia do roku 1999, Lublin 2002, wg indeksu.

${ }^{7}$ Anonima tzw. Galla Kronika czyli dzieje ksiażąt i władców polskich, wyd. K. Maleczyński (Monumenta Poloniae Historica. Series nova [dalej: MPHsn], t. 2), Kraków 1952, s. 43. W przedmiocie owej klątwy zob. ostatnio: Labuda, Droga życiowa Radzima-Gaudentego, s. 190.

${ }^{8}$ Zob. Kronika Boguchwała i Godystawa Paska, wyd. W.A. Maciejowski, [w:] Monumenta Poloniae Historica [dalej cyt.: MPH], t. 2, Lwów 1872, s. 482-483 (gdzie mowa o ustanowieniu pierwszych polskich biskupstw i - osobno - o zjeździe gnieźnieńskim). Nadto: Polska - dzieje i rzeczy jej rozpatrywane przez Joachima Lelewela, t. 1, Poznań 1858, s. 7, nr XIX; B. Kürbisówna, Dziejopisarstwo wielkopolskie XIII i XIV wieku, Warszawa 1959, s. 15-20, 90-224; J. Dąbrowski, Dawne dziejopisarstwo polskie (do roku 1480), Wrocław-Warszawa-Kraków 1964, s. 130-140; W. Drelicharz, Annalistyka małopolska XIII-XV wieku. Kierunki rozwoju wielkich roczników kompilowanych, Kraków 2003, s. 211-262.

${ }^{9}$ Zob. Mierzwy kronika, wyd. A. Bielowski, MPH, t. 2, s. 188-189 (gdzie także mowa o dwóch metropoliach za czasów Bolesława Chrobrego, wszakże z konkretnym wskazaniem na Kraków 
Kronika książat polskich ${ }^{10}$. Dopiero też dzięki Janowi Długoszowi imię pierwszego metropolity gnieźnieńskiego na powrót zagościło na kartach dzieł opisujących ojczyste dzieje, należących już wszakże do nowożytnego piśmiennictwa staropolskiego. Cała zresztą spuścizna tego polihistora, zmarłego nominatem na arcybiskupstwo lwowskie, lokuje się niejako na styku rodzimego kronikarstwa średniowiecznego i pisarstwa historiograficznego epoki nowożytnej, w przypadku owego pierwszego stanowiąc swego rodzaju uwieńczenie, natomiast pod to drugie kładąc solidny fundament i zarazem wyznaczając horyzonty, poza które rzadko kiedy wykraczano aż do czasu podjęcia nowocześnie rozumianych badań historycznych ${ }^{11}$. Z tym większą zatem uwagą należy przyjrzeć się, co o Radzimie-Gaudentym był w stanie napisać, sięgając do dostępnej sobie podstawy źródłowe, Jan Długosz tudzież jakie nowe wątki w biografii rzeczonego arcybiskupa Gniezna jemu właśnie zawdzięczamy.

Informacje o obdarzonym godnością arcybiskupią bracie św. Wojciecha XVwieczny krakowski kanonik pomieścił w dwóch dziełach, mianowicie w Annales seu cronicae inclyti Regni Poloniae i w swego pióra katalogu arcybiskupów gnieźnieńskich, wraz z pięcioma innymi katalogami pasterzy polskich diecezji (Kraków, Płock, Poznań, Włocławek, Wrocław) tworzącym zbiór Vitae episcoporum Poloniae ${ }^{12}$. Na kartach Annales Długosz pisze o bł. Radzimie-Gaudentym w odniesieniu do lat 989, 994, 997, 999, 1001, 1006 i 1038, przedstawiając jego losy zarówno w okresie przed, jak i po powołaniu do godności metropolity pol-

i Gniezno). Nadto: Polska - dzieje i rzeczy jej rozpatrywane przez Joachima Lelewela, t. 1, s. $8 \mathrm{nr}$ XXI; Dąbrowski, Dawne dziejopisarstwo polskie, s. 120-122.

${ }^{10}$ Zob. Kronika książąt polskich, wyd. Z. Węclewski, MPH, t. 3, Lwów 1878, s. 439-440; nadto Dąbrowski, Dawne dziejopisarstwo polskie, s. 165-168; R. Heck, Kronika ksiażąt polskich - metoda prezentacji dziejów, w: Dawna historiografia ślaska, red. K. Gajda, Opole 1980, s. 6181; J. Kopiec, Historiografia diecezji wrocławskiej do roku 1821, „Archiwa, Biblioteki i Muzea Kościelne", 45 (1982) s. 249-250; Drelicharz, Annalistyka małopolska XIII-XV wieku, s. 296-313; także P. Bering, Struktury narracyjne w późnośredniowiecznych łacińskich kronikach regionalnych, Gniezno 2001, passim.

11 M.in. J. Szujski, Stanowisko Dlugosza w historiografii europejskiej, Kraków 1880; M. Bobrzyński, S. Smolka, Jan Dlugosz - jego życie i stanowisko w piśmiennictwie, Kraków 1893; Dlugossiana. Studia historyczne w pięćsetlecie śmierci Jana Dlugosza, t. [1], red. S. Gawęda, Kraków 1980 (tamże zwł. artykuł S. Cynarskiego, Uwagi nad problemem recepcji „,Historii” Jana Dlugosza w Polsce XVI i XVII wieku - s. 281-292); t. 2, red. S. Gawęda, Kraków 1985 (m.in.: U. Borkowska, Historiograficzne poglady Jana Dlugosza - s. 45-71); H. Barycz, Szlakami dziejopisarstwa staropolskiego. Studia nad historiografia w. XVI-XVIII, Wrocław-Warszawa-KrakówGdańsk 1981, s. 71-130; U. Borkowska, Treści ideowe w dziełach Jana Dlugosza. Kościót i świat poza Kościołem, Lublin 1983; P. Dymmel, Tradycja rękopiśmienna „Roczników” Jana Dlugosza. Studium analityczne ksiag X-XII, Warszawa 1992 (zwł. s. 5nn); Słownik historyków polskich, red. M. Prosińska-Jackl, Warszawa 1994, s. 109-111; Dawni pisarze polscy od początków piśmiennictwa do Młodej Polski. Przewodnik biograficzny i bibliograficzny, t. 1, Warszawa 2000, s. 227-233 (T. Witczak); A.F. Grabski, Zarys historii historiografii polskiej, Poznań 2000, s. 25-26.

12 Zob. Dąbrowski, Dawne dziejopisarstwo polskie, s. 212-213; W. Baran-Kozłowski, Arcybiskup gnieźnieński Henryk Kietlicz (1199-1219). Działalność kościelna i polityczna, Poznań 2005, s. 20. 
skiej prowincji kościelnej ${ }^{13}$. W warstwie faktografii tylko do pewnego stopnia jest on zależny od żywotopisarzy św. Wojciecha, w ślad za którymi podaje informacje o wspólnych etapach drogi życiowej obu Sławnikowiców. Wspomina więc o pobycie Radzima u boku przyrodniego brata w Wiecznym Mieście i wstąpieniu przezeń do benedyktynów (,[Sanctus Adalbertus] Rome consistens, consilio virorum religiosorum monasterii sancti Alexii et Bonifacii ingressus, vitam monasticam in vite artitudine agere cepit, fratre suo beate vite Gaudencio in eodem monasterio secum una delitescente pro sue conversacione et vite studio") ${ }^{14}$, podobnie jak i o ich wyprawie na Węgry („,cum Gaudencio ceterisque religiosis viris Hungariam [sanctus Adalbertus] ingressus [est]") ${ }^{15}$. Co się tyczy wszakże wydarzeń roku 997 oraz lat kolejnych, w przedstawianiu losów bł. Gaudentego oraz okoliczności jego wyniesienia do godności arcybiskupiej Jan Długosz, miast trzymać się skądinąd dość skąpych wiadomości, zawartych w najstarszych żywotach świątowojciechowych tudzież innych współczesnych (lub niewiele późniejszych źródłach), zdecydował się oprzeć swą narrację na - co dziś jawi się dla nas oczywistym, ale wówczas z pewnością takim nie było - niewiarygodnych świadectwach i bałamutnych przekazach o późniejszej genezie. I tak o wyprawie misyjnej do Prus przyszłego patrona polskiej prowincji kościelnej czytamy pod rokiem 997, że rozpoczęła się ona po tym, jak św. Wojciech „Gneznensem sedem deserit, fratre suo Gaudencio pro se archiepiscopo Gneznensi ordinato" Według XV-wiecznego dziejopisa Radzim-Gaudenty nie towarzyszył tedy starszemu bratu w podróży na ziemie Prusów i nie był naocznym świadkiem jego męczeństwa ${ }^{17}$, już przedtem bowiem przyszło mu przejąć ster odpowiedzialności za Kościół gnieźnieński.

${ }^{13}$ Joannis Dlugossii seu Longini, canonici Cracoviensis, Historiae Polonicae libri XII, t. 1 Libri I., II., III. [et] IV., ed. I. Ż. Pauli (Joannis Dlugosz Senioris, canonici Cracoviensis, opera omnia, t. 10), Cracoviae 1873, s. 139-140 (r. 989), 147-148 (r. 994), 151 (r. 997), 159-160 (r. 999), 164-169 (r. 1001), 190-191 (r. 1006), 250-253 (r. 1038); Joannis Dlugossii Annales seu cronicae incliti Regni Poloniae. Liber primus - Liber secundus, cur. J. Dąbrowski, Varsaviae 1964, s. 202-203 (r. 989), 210-211 (r. 994), 215 (r. 997), 223-224 (r. 999), 228-233 (r. 1001), 256-257 (r. 1006), 319-322 (r. 1038).

${ }^{14}$ Joannis Dlugossii seu Longini, canonici Cracoviensis, Historiae Polonicae libri XII, t. 1, s. 140; Joannis Dlugossii Annales seu cronicae incliti Regni Poloniae. Liber primus - Liber secundus, s. 203 (rok 989). Por. Świętego Wojciecha, biskupa i męczennika, żywot pierwszy, wyd. J. Karwasińska (MPHsn, t. 4 cz. 1), Warszawa 1962, s. 24; Najdawniejsze roczniki krakowskie $i$ kalendarz, wyd. Z. Kozłowska-Budkowa (MPHsn, t. 5), Warszawa 1978, s. 44, 232 (rok 990); W kręgu żywotów świętego Wojciecha, red. J. A. Spież, Kraków 1997, s. 58-59. Także A. Semkowicz, Krytyczny rozbiór «Dziejów polskich» Jana Dlugosza (do roku 1384), Kraków 1887, s. 85; G. Labuda, Mieszko I, s. 214-215.

${ }^{15}$ Joannis Dlugossii seu Longini, canonici Cracoviensis, Historiae Polonicae libri XII, t. 1, s. 147; Joannis Dlugossii Annales seu cronicae incliti Regni Poloniae. Liber primus - Liber secundus, s. 210-211 (rok 994). Por. W kręgu żywotów świętego Wojciecha, s. 142, 161, 185-186. Także Semkowicz, Krytyczny rozbiór «Dziejów polskich», s. 87.

${ }^{16}$ Joannis Dlugossii seu Longini, canonici Cracoviensis, Historiae Polonicae libri XII, t. 1, s. 151; Joannis Dlugossii Annales seu cronicae incliti Regni Poloniae. Liber primus - Liber secundus, s. 215 (rok 997). Także Semkowicz, Krytyczny rozbiór «Dziejów polskich», s. 90-91.

${ }^{17}$ Por. Świętego Wojciecha, biskupa i męczennika, żywot pierwszy, s. 41; Świętego Wojciecha, 
Owo rzekome przejęcie rządów w archidiecezji, która wszak wtenczas jeszcze nie istniała, wiąże się bezpośrednio z okolicznością opowiedzenia się Długosza za uznaną przez historiografię staropolską poniekąd za „,kanoniczną” tradycją o ufundowaniu od razu w roku 966 przez Mieszka I dwóch metropolii kościelnych - w Gnieźnie i Krakowie, oraz siedmiu biskupstw: poznańskiego, smogorzowskiego, kruszwickiego, płockiego, chełmińskiego, lubuskiego i kamieńskiego $^{18}$. Rozwodząc się obszernie na ten temat, XV-wieczny dziejopis wymienia też imiona hierarchów, którzy rzekomo jako pierwsi mieli zasiadać na wyliczonych wyżej stolicach, utrzymując przy tym, że ta rozbudowana organizacja diecezjalna została potwierdzona i usankcjonowana przez wysłanego do Polski i działającego w imieniu papieża Jana XIII kardynała Idziego (Egidiusza), biskupa Tusculum ${ }^{19}$. Tak więc za pierwszego arcybiskupa Gniezna Jan Długosza uważa Wilibalma (Wilibalmusa), którego śmierć kładzie na rok 970, po nim z kolei miał nastąpić Hatto, zmarły jakoby już w roku 971, zaś po tym Robert (jego rządy pasterskie miały trwać bez mała ćwierć wieku - do r. 995), „cui Adalbertus, Pragensis ar-

biskupa i męczennika, żywot drugi, napisany przez Brunona z Kwerfurtu, wyd. J. Karwasińska (MPHsn, t. 4 cz. 2), Warszawa 1969, s. 34 nn.

${ }_{18}$ Joannis Dtugossii seu Longini, canonici Cracoviensis, Historiae Polonicae libri XII, t. 1, s. 117-118; Joannis Dlugossii Annales seu cronicae incliti Regni Poloniae. Liber primus - Liber secundus, s. 178-179 (rok 966). Zob. Semkowicz, Krytyczny rozbiór «Dziejów polskich», s. 77-79 (gdzie czytamy m.in., iż „Długosz sam przyznaje w tym ustępie, że nie czerpie ze świadectw piśmiennych; zdaje się jednak, że wątku do skreślenia tego ustępu dostarczył mu Rocznik Traski, który pod rokiem 965 wspomina o założeniu biskupstw, klasztorów i kościołów przez Mieczysława [ $t j$. Mieszka I]”). Por. Rocznik Traski, wyd. A. Bielowski, MPH, t. 2, Lwów 1872, s. 828: „Anno Domini 965 excellentissimus dux Mescho accepit Dobrovcam sibi in uxorem [...], qui ambo christiani fidelissimi in Polonia efficiuntur et omnes Poloni baptizantur, ecclesiae et claustra, episcopatus, praepositurae alique per ipsos, que tunc fieri poterant construuntur et dotantur".

${ }^{19}$ Joannis Dlugossii seu Longini, canonici Cracoviensis, Historiae Polonicae libri XII, t. 1, s. 119; Joannis Dlugossii Annales seu cronicae incliti Regni Poloniae. Liber primus - Liber secundus, s. 180. Zob. Semkowicz, Krytyczny rozbiór «Dziejów polskich», s. 78, gdzie badacz ów stwierdza niemniej: „Nie sądzę, aby imiona pierwszych biskupów polskich były przez Długosza zmyślone, ale zdaje mi się, że takowe, chociaż są mylne, z zaginionych dzisiaj spisów przeszły do dzieła jego. [...] Co do arcybiskupów gnieźnieńskich, to dzisiaj już rzecz pewna, że pierwsi trzej przeszli do spisów polskich z katalogów arcybiskupów mogunckich". W tym kontekście należy zauważyć, że nie we wszystkich przypadkach podstawę dla dodania do wykazów imion owych legendarnych hierarchów musiały stanowić spisy pasterzy jakichś innych, obcych Kościołów partykularnych. Przykładowo imię rzekomego biskupa kamieńskiego Juliana nasuwa niedwuznaczne skojarzenia z Julinem, czyli łacińską nazwą Wolina, który wszak był pierwotną stolicą biskupów pomorskich po ukonstytuowaniu tu diecezji w roku 1140. Jakiś późniejszy autor mógł tedy z owej nazwy geograficznej nieświadomie uczynić (czy też - przeciwnie - świadomie urobić) imię osoby i umieścić je na początku pocztu pasterzy diecezji kamieńskiej. Co się tyczy z kolei rzekomego wysłania przez papieża Jana XIII legata do kraju Mieszka I, to mamy tu do czynienia najwyraźniej z przeniesieniem o przeszło 150 lat wstecz historycznego faktu legacji do Polski z lat 1123-1124 kardynała-biskupa Tusculum Idziego (Egidiusza), będącego wysłannikiem papieża Kaliksta II, z imieniem którego to hierarchy rzeczywiście wiąże się rozbudowa organizacji diecezjalnej Kościoła polskiego - tyle, że dopiero za czasów Bolesława III Krzywoustego. 
chiepiscopus [sic], genere nobilis de Rosarium domo, succedit"20. Bł. RadzimGaudenty zajmuje zatem u Długosza dopiero piąte miejsce w poczcie gnieźnieńskich metropolitów, w którym poprzedza go św. Wojciech, ten zaś miał być jakoby następcą właśnie owego Roberta ${ }^{21}$.

Rzekome ustąpienie ze stolicy arcybiskupiej w Gnieźnie przez późniejszego męczennika na rzecz przyrodniego brata, przed udaniem się na wyprawę misyjną do Prus, w żadnym wypadku nie jest jednak własnym wymysłem tegoż XVwiecznego autora. $Z$ takim właśnie ujęciem zagadnienia spotykamy się po raz pierwszy już w już w XIII-wiecznej redakcji tzw. Legendy o św. Wojciechu (De sancto Adalberto episcopo), rozpoczynającej się od słów „Tempore illo"22, jak i w pochodzących z tego samego stulecia Cudach św. Wojciecha (Miracula sancti Adalberti) ${ }^{23}$ oraz Żywocie mniejszym św. Stanisława (Vita minor sancti Stanislai, episcopi Cracoviensis) ${ }^{24}$. Autor właśnie tego ostatniego zabytku piśmiennictwa,

${ }^{20}$ Joannis Dlugossii seu Longini, canonici Cracoviensis, Historiae Polonicae libri XII, t. 1, s. 125 (r. 970), 126 (r. 971), 149 (r. 995); Joannis Dlugossii Annales seu cronicae incliti Regni Poloniae. Liber primus - Liber secundus, s. 186 (rok 970), 187 (rok 971), 212 (rok 995). Zob. także Semkowicz, Krytyczny rozbiór «Dziejów polskich», s. 80, 81, 88.

${ }^{21}$ Joannis Dlugossii seu Longini, canonici Cracoviensis, Historiae Polonicae libri XII, t. 1, s. 150; Joannis Dlugossii Annales seu cronicae incliti Regni Poloniae. Liber primus - Liber secundus, s. 214-215: „Contigit autem pro illo tempore [...] Robertum Gnesnensem archiepiscopum mori, cuius locum beatus Adalbertus, maximis ducis Myeczyslai et filii eius Boleslai et totius cleri et populi instantiis devictus suscepit”; oraz powtórnie: „Vaccacione Gneznensis Ecclesiae per mortem Roberti secuta, vir celebris Adalbertus [...], Pragensis episcopus, opera Boleslai Chrabri ducis et monarchae Poloniae in sedem Gneznensem suffectus est”. I dalej: „Estuans vir Dei Adalbertus, Gneznensis archiepiscopus, ignito et flagranti desiderio lauream martiri suscipere, de qua percipienda visione sibi monstrata certificatus erat [...]. Hac itaque visione vehementer instigatus, non sine ducis Myeczyslavi Poloniae et filii sui ducis Boleslai molestia et dolore, Gneznensem sedem deserit et fratre suo Gaudencio pro se archiepiscopo Gneznensi ordinato, $[\ldots]$ versus Prutenorum regione $[\ldots]$ pergit".

${ }^{22}$ De sancto Adalberto episcopo, wyd. W. Kętrzyński, MPH, t. 4, Lwów 1884, s. 217 („Sanctus [Adalbertus] fundamentum apostolorum et prophanorum [in Polonia] stabilire cupiens, quendam christianissimum virum, sui socium laboris et itineris, Gaudencium nomine, ibidem archiepiscopum pro se constituit, quia ipse videlicet ad alias regiones paganorum festinabat, quas lucrifacere Christo nihilominus anelabat"); W kręgu żywotów świętego Wojciecha, s. 191 (gdzie polski przekład odnośnego fragmentu). Zob. także Dąbrowski, Dawne dziejopisarstwo polskie, s. 85-86; G. Labuda, Nad legenda o św. Wojciechu «Tempore illo». Analiza źródtoznawcza, w: Ecclesia Posnaniensis, red. F. Lenort i K. Lutyński, Poznań 1998, s. 11-31 (zwł. s. 20-22, 31); Labuda, Mieszko I, s. 135; Labuda, Święty Wojciech, s. 274-284.

${ }^{23}$ Miracula sancti Adalberti, wyd. W. Kętrzyński, MPH, t. 4, s. 231 § („Etiam legitur, quod volens beatus Adalbertus transire ad terras alias paganorum, socium laboris et itineris sui, virum sanctum nomine Gaudencium, in Gnezna pro se archiepiscopum constituit"); W kregu żywotów świętego Wojciecha, s. 207 (polski przekład odnośnego fragmentu). Zob. także Dąbrowski, Dawne dziejopisarstwo polskie, s. 86-87.

${ }^{24}$ Vita s. Stanislai, episcopi Cracoviensis (vita minor), wyd. W. Kętrzyński, MPH, t. 4, s. 268 (,,[Sanctus Adalbertus], divino inspiratus consilio, comilitonem et socium suum, fratrem Gaudencium, loco sui archiepiscopum instituit [in Gneznensi metropolitana civitate]"); Wincentego z Kielc żywot mniejszy i żywot większy św. Stanisława, przeł. J. Pleziowa, „Analecta Cracoviensia” 11 (1979), s. 156 (polski przekład). Zob. także Polska - dzieje i rzeczy jej rozpatrywane przez 
w świetle ustaleń poczynionych przez G. Labudę, ma też ponosić odpowiedzialność za wprowadzenie do „obiegu” owej bałamutnej wiadomości, wydedukowanej przezeń z kroniki Galla Anonima, gdzie o pierwszym arcybiskupie Gniezna mowa jest, że był to „frater et success or sancti Adalberti”" ${ }^{5}$. Należy wszakże zwrócić przy tym uwagę, że owe Gallowe sformułowanie, nawet w ten sposób zinterpretowane, nie daje podstawy dla przyjęcia, że Radzim-Gaudenty ,a Beato Adalberto suffectus est”, jak pisze Długosz ${ }^{26}$, a co powtórzy później za nim większość spośród staropolskich historiografów, którym dla jakichś względów przyszło wspomnieć o osobie młodszego z obdarzonych biskupią infułą Sławnikowiców. Tego rodzaju przedstawienie tamtych wydarzeń może zatem stanowić pochodną własnej inwencji zmarłego nominatem na arcybiskupstwo lwowskie dziejopisa, co się natomiast tyczy samego rozbudowanego pocztu metropolitów Gniezna, przezeń podanego, to zapewne w owej materii J. Długosz oparł się - jak słusznie odgaduje A. Semkowicz - na starszych, nie zachowanych do dziś dnia katalogach arcybiskupów gnieźnieńskich (o czym niżej jeszcze) ${ }^{27}$.

Autor Annales seu cronicae inlclyti Regni Poloniae odznaczał się zbyt wielką erudycją i zarazem akrybią, by nie zwrócić uwagi na najstarsze zabytki rocznikarskie i zawarte w nich informacje. W przypadku Radzima-Gaudentego dowód spożytkowania przez Jana Długosza również tej kategorii źródeł dostrzegamy w passusie widniejącym w drugiej księdze Roczników pod datą 999, gdzie czytamy: „Beato viro Adalberto, Gneznensi archiepiscopo, ad praedicandam fidem Christi gentibus in Prussiam profecto, beatus Gaudencius, qui alio nomine Radzim vocabatur, frater germanus beati Adalberti secundum carnem, Gneznensem kathedram a beato viro Adalberto suffectus, suscepit, genere Bohemus et nobilitate clarus, eidem praentibus, quibus et beatus Adalbetus, Slawniko et Strzeszislawa ortus, nobilis de domo Rosze et ea familia, que se Poray nuncupat, roszam rubeam pro insigni deferens" ${ }^{28}$ (ta sama wiadomość w Długoszowym katalogu arcybiskupów

Joachima Lelewela, t. 1, s. 7-8 nr XX; Dąbrowski, Dawne dziejopisarstwo polskie, s. 87-90; G. Labuda, Nad legenda o św. Wojciechu..., s. 21-22, 31.

${ }^{25}$ M.in. Labuda, Święty Wojciech, s. 283-285 (gdzie też w przyp. 586 zestawienie stosownych tekstów źródłowych). Por. Semkowicz, Krytyczny rozbiór «Dziejów polskich», s. 88, 92. Warto zwrócić tu uwagę, że zarówno w Legendzie o św. Wojciechu, jak i w Cudach św. Wojciecha, z owego określenia „frater et successor” przeoczono w zupełności pierwszy człon, związki łączące Radzima-Gaudentego z Wojciechem sprowadzając do wymiaru „socius laboris et itineris” (zob. odnośne cytaty w poprzednich dwóch przypisach). Zob. nadto: W. Korta, Średniowieczna annalistyka śląska, Wrocław 1966, s. 164-166 (próba wyjaśnienia genezy przypisania św. Wojciechowi godności arcybiskupa Gniezna - zwł. s. 166 i tamże przyp. 78, gdzie kuriozalna uwaga, jakoby błąd tego rodzaju popełnił w swojej kronice już Gall Anonim, na dowód czego przywołane zostało właśnie owo mylnie interpretowane określenie „frater et successor”).

${ }^{26}$ Joannis Dlugossii senioris, canonici Cracoviensis, opera, t. 1, ed. I. Polkowski et Ż. Pauli, Cracoviae 1887, s. 345 (Catalogus archiepiscoporum Gnesnensium): „Beato Adalberto ad praedicandam fidem Christi gentibus in Prussia profecto, beatus Gaudentius, qui alio nomine Radzim vocaretur, Gnesnensem cathedram, a beato viro Adalberto suffectus, suscepit, anno Domini nongentesimo nonagesimo nono in archiepiscopum Gnesnensem ordinatus".

${ }^{27}$ Zob. wyżej przyp. 18.

${ }^{28}$ Joannis Dlugossii seu Longini, canonici Cracoviensis, Historiae Polonicae libri XII, t. 1, s. 
gnieźnieńskich) ${ }^{29}$. Mamy tu zatem do czynienia z do pewnego stopnia osobliwym wpleceniem treści oryginalnej zapiski rocznikarskiej, wzmiankującej o sakrze biskupiej Radzima-Gaudentego, w zawierającą bałamutne treści narrację opartą na przekazach zawartych w późniejszych świadectwach. Tu również pojawia się informacja, że obaj ci synowie Sławnika pochodzili jakoby z jednej matki i byli tym samym rodzonymi braćmi (a nie - jak w rzeczywistości - przyrodnimi), co tak samo zostanie podchwycone przez później piszących autorów i powtórzone na kartach wielu dzieł ${ }^{30}$.

Dostrzegamy zatem w sposób wyraźny, że w odnoszącym się do osoby bł. Radzima-Gaudentego i jego losów zbiorze wiadomości, podanych przez Długosza, zmieszane zostały ze sobą zarówno takie informacje, co do których nie mamy trudności z ustaleniem źródła ich pochodzenia, jak i te, których geneza pozostaje niewyjaśniona. Co się tyczy owej drugiej grupy, w niektórych przypadkach władni jesteśmy ponad wszelką wątpliwość stwierdzić, że nie odpowiadają one prawdzie historycznej (jak to ma miejsce chociażby przy zawartym pod rokiem 1001 opisie koronacji Bolesława I Chrobrego podczas wizyty cesarza Ottona III w Gnieźnie) ${ }^{31}$, gdzie indziej jednak - i to stanowi największe wyzwanie dla badaczy - trudno (lub zgoła nie sposób) rozstrzygnąć, czy te nie znane skądinąd fakty z zamierzchłej przeszłości, podane przez XV-wiecznego dziejopisa, zasługują na wiarę, tudzież skąd mógł je zaczerpnąć. Tak właśnie rzecz się przedstawia, gdy idzie o określenie przez Jana Długosza czasu zasiadania Radzima-Gaudentego na gnieźnieńskiej stolicy metropolitalnej na lat siedem i przyporządkowania jego zgonu do roku 1006. Tak postąpił zarówno w Annales, jak i w katalogu arcybiskupów Gniezna, przy czym zawarty tamże życiorys interesującej nas postaci przynosi te same informacje o jej curriculum vitae, jakie znajdujemy we wskazanych tu wcześniej zapiskach rocznikarskich - przede wszystkim z roku 999 i 1006 (za Gallem Anonimem przytoczył także informację o klątwie, która miała po latach pociągnąć za sobą skutek w postaci niszczycielskiego najazdu Czechów z roku 1038, przy czym już sam od siebie dodał, że klątwa ta, rzucona „ob multitudinem immanium scelerum", odnosić się miała do samego tylko miasta Gniezna) ${ }^{32}$.

159; Joannis Dlugossii Annales seu cronicae incliti Regni Poloniae. Liber primus - Liber secundus, s. 223-224. Już zresztą pod rokiem 997 mowa jest, że „non sine ducis Myeczyslai Poloniae et filii sui ducis Boleslai molestia et dolore, Gnesnensem sedem [sanctus Adalbertus] deserit, fratre suo Gaudentio pro se archiepiscopo Gnesnensi ordinato" (Joannis Dlugossii seu Longini, canonici Cracoviensis, Historiae Polonicae libri XII, t. 1, s. 151; Joannis Dlugossii Annales seu cronicae incliti Regni Poloniae. Liber primus - Liber secundus, s. 215).

${ }^{29}$ Zob. wyżej cytat w przyp. 25. Por. Najdawniejsze roczniki krakowskie, s. 44 (rok 999).

${ }^{30}$ Por. np. Semkowicz, Krytyczny rozbiór «Dziejów polski», s. 92; W kręgu żywotów świętego Wojciecha, s. 162; G. Labuda, Święty Wojciech..., s. 229.

${ }^{31}$ Joannis Dtugossii seu Longini, canonici Cracoviensis, Historiae Polonicae libri XII, t. 1, s. 168; Joannis Dlugossii Annales seu cronicae incliti Regni Poloniae. Liber primus - Liber secundus, s. 229, 232. Zob. także Semkowicz, Krytyczny rozbiór «Dziejów polskich», s. 92-93.

${ }^{32}$ Joannis Dlugossii senioris, canonici Cracoviensis, opera, t. 1, s. 345; Joannis Dlugossii seu Longini, canonici Cracoviensis, Historiae Polonicae libri XII, t. 1, s. 252-253; Joannis Dlugossii Annales seu cronicae incliti Regni Poloniae. Liber primus - Liber secundus, s. 256-257. O najeździe na Polskę księcia czeskiego Brzetysława I i uwiezieniu z Gniezna do Pragi ciała arcybi- 
I w tym przypadku wysuwano przypuszczenie, iż Długosz mógł oprzeć się na jakichś nieznanych nam dzisiaj zapiskach rocznikarskich czy też starszych katalogach arcybiskupów gnieźnieńskich, również do naszych czasów niedochowanych. Jeśli rzeczywiście takowe miał $\mathrm{w}$ ręku, to były one jednak do pewnego stopnia bałamutne, co jasno zdaje się wynikać z podkreślonego tu już wcześniej faktu, że Radzima-Gaudentego XV-wieczny historiograf umieścił w poczcie metropolitów Gniezna dopiero na piątym miejscu (po trzech arcybiskupach Moguncji oraz św. Wojciechu), choć bynajmniej nie przesądza to jeszcze, że również niewiarygodną musi być i data roczna śmierci tegoż hierarchy. W każdym razie pomieszczony w dziełach Jana Długosza zasób wiadomości o osobie pierwszego zwierzchnika polskiej prowincji kościelnej stać się miał na długi czas „obowiązującym kanonem", powtarzanym przez kolejnych staropolskich dziejopisów, wzmiankujących w swych dziełach o początkach organizacji diecezjalnej w Polsce tudzież o osobie samego bł. Radzima-Gaudentego.

Co się zaś tyczy katalogów arcybiskupów gnieźnieńskich, to znamy takowe dopiero z bardzo późnego okresu, bowiem najstarszy zachowany, łączony z osobą łysogórskiego benedyktyna Macieja z Pełczyna, pochodzi z drugiej połowy XV w., a tym samym ów Długoszowy jest de facto mu współczesny. Kolejne ocalałe do naszych czasów katalogi powstały już w XVI stuleciu i - jak podkreśla J. Dąbrowski - „dla XI i XII w. nie posiadają one zupełnie wartości”’33. W owym pierwszym, spisanym w latach 1449-1454 oraz 1474, przy Radzimie-Gaudentym opuszczono zarówno informację, przez jak długi czas sprawować miał swój urząd, jak i rok śmierci, w kolejnych natomiast pojawia się już w tym kontekście-w ślad właśnie za Długoszem (jego Catalogus sporządzony został w r. 1476) - liczba siedem oraz rok $1006^{34}$. Trudno też nie wspomnieć tu, że imię pierwszego metropolity Gniezna występuje nadto w XV- i XVI-wiecznych redakcjach katalogu biskupów krakowskich, przy biskupie Prokulfie, gdzie mowa jest, iż „huius tempore beatus Adalbertus, secundus Pragensis episcopus, Poloniam ex Ungaria venit et Polonos in fide Christi adhuc novicios confortavit cum fratre Gaudencio" (tak w redakcji z kodeksu znanego nam już benedyktyna świętokrzyskiego Macieja z Pełczyna oraz w tzw. redakcji lubelskiej z lat 1503-1508) ${ }^{35}$. Z kolei tzw. dominikańska redakcja owego katalogu powtarza wiadomość, jakoby to św. Wojciecha „Boleslaus, dux Polonorum, assumens in cathedra metropolis Gneznensis fecit

skupa Radzima-Gaudentego jakoby w przekonaniu, iż są to szczątki wyniesionego do chwały ołtarzy biskupa Pragi - tamże, s. 321 (rok 1038). Zob. również Semkowicz, Krytyczny rozbiór «Dziejów polskich», s. 97, 110-111.

${ }^{33}$ Dąbrowski, Dawne dziejopisarstwo polskie, s. 112. Zob. także: Nieznany katalog arcybiskupów gnieźnieńskich, wyd. B. Bolz, „Archiwa, Biblioteki i Muzea Kościelne”, 11 (1965) s. 271-276; Baran-Kozłowski, Arcybiskup gnieźnieński Henryk Kietlicz, s. 20-21.

${ }^{34}$ Katalogi arcybiskupów gnieźnieńskich, wyd. K. Liske, MPH, t. 3, s. 392, 405; Nieznany katalog arcybiskupów gnieźnieńskich, s. 280 („Gaudentius, divi Adalberti frater, fratri divina providentia successit, Boleslaum Chabri in regem Polonicum unxit et corona a cesare Ottone III. Gnesnae peregrinante coronavit. Annis septem sedit, mortuus anno Domini 1006").

${ }^{35}$ Katalogi biskupów krakowskich, wyd. W. Kętrzyński, MPH, t. 3, s. 332-333; Catalogi episcoporum Cracoviensium, ed. J. Szymański (MPHsn, t. 10 cz. 2), Warszawa 1974, s. 53, 109. 
presidere; qui volens ad regiones paganorum proficisci, socium sui itineris et fratrem germanum Radzim alias Gaudencium nomine, archiepiscopum ibidem constituit”36. By zaś zamknąć temat późnośredniowiecznych katalogów pasterzy diecezji polskich, należy wspomnieć, że również w katalogu biskupów krakowskich Jana Długosza, bliźniaczym względem owego gnieźnieńskiego, pojawia się pojedyncza wzmianka o bł. Radzimie-Gaudentym, a to przy informacji o wyimaginowanej koronacji Bolesława I Chrobrego na króla Polski „sub praesentia Otthonis tertii, Romanorum imperatoris". Mianowicie kładąc na ten czas pontyfikat w Kościele krakowskim Lamberta (I), XV-wieczny historiograf stwierdza: „Ipse quoque Lambertus, Cracoviensis archiepiscopus, in Gnesnensi ecclesia praesens affuit, quando [...] coronatur Boleslaus Chrabri, primus Poloniae rex. Ipse quoque Lambertus, archiepiscopus Cracoviensis, cum Gaudentio, Gnesnensi archiepiscopo, coronationis et unctionis regie munus, alias omnibus episcopis Polonicae ecclesiae assistentibus, praefato Boleslao Chrabri regi Poloniae impendit" 37 .

Jeszcze w nurt średniowiecznego piśmiennictwa poniekąd też wpisuje się XVI-wieczna Kronika o Piotrze Wtaście (Cronica Petri comitis), w której połączenie znalazły obie zasygnalizowane tu już tradycje odnośnie do rzekomego związku św. Wojciecha ze stolicą arcybiskupią w Gnieźnie oraz roli, jaka przypadła w tym kontekście bł. Radzimowi-Gaudentemu. O ile i tu wyczytujemy, że późniejszy patron Królestwa Polskiego i polskiej prowincji kościelnej był jakoby metropolitą gnieźnieńskim, o tyle nie powtórzono nie mniej bałamutnej informacji o przekazaniu przezeń steru rządów w tymże Kościele partykularnym

${ }^{36}$ Katalogi biskupów krakowskich, s. 332-333; Catalogi episcoporum Cracoviensium, s. 79. Zob. nadto Dąbrowski, Dawne dziejopisarstwo polskie, s. 109-111; G. Labuda, O katalogach biskupów krakowskich przed Dlugoszem, „Studia Źródłoznawcze”, 27 (1983) s. 83-96; Drelicharz, Annalistyka matopolska XIII-XV wieku, s. 143-185.

${ }^{37}$ Joannis Dlugossii senioris, canonici Cracoviensis, opera, t. 1, s. 383; MPHsn, t. 10 cz. 2, s. 138-139. Należy na marginesie dodać tytułem wyjaśnienia, że tak w Długoszowej, jak i w pozostałych XV-wiecznych redakcjach katalogów biskupów krakowskich, kolejni pasterze tej diecezjido zmarłego w roku 1059 Aarona włącznie - tytułowani są arcybiskupami. Wzięło się to stąd, że do następcy tegoż Aarona na biskupstwie w Krakowie, Lamberta-Suły, odnosi się nie wiadomo kiedy po raz pierwszy zanotowana wiadomość, utrwalona w co najmniej kilku średniowiecznych zabytkach rocznikarskich (oraz w opartym na starszej podstawie źródłowej katalogu Jana z Dąbrówki), że ten to hierarcha „neglexit archiepiscopatum” (Catalogi episcoporum Cracoviensium, s. 31 i tamże przyp. 18). Dodatkowo mogła posłużyć tu za fundament (i zapewne posłużyła) podana przez Galla Anonima, a powtórzona przez Wincentego Kadłubka, informacja o dwóch metropoliach w Polsce za czasów Bolesława Chrobrego (zob. wyżej. s. $\underline{3}$ ). Jak bardzo zaś żywotna okazała się tradycja o stolicy arcybiskupiej w Krakowie za pierwszych Piastów, może świadczyć relacja z r. 1568 nuncjusza apostolskiego Giulio Ruggieriego dla papieża Piusa V o Polsce i tutejszym Kościele, w której czytamy m.in., że „nella Polonia Minore è [la Chiesa] Cracoviense, che altre volte fu metropoli, e per tale memoria li vescovi di essa oggi usano di portare un pallio, senza benedizione o auttorità alcuna, tutto ricamato di perle, in cambio del vero che solevano havere da Roma" (Acta nuntiaturae Polonae, t. 6 - Iulius Ruggieri (1565-1568), coll. T. Glemma, ed. S. Bogaczewicz, Romae 1991, s. 176; toż w polskim tłumaczeniu: Relacye nuncyuszów apostolskich i innych osób o Polsce od roku 1548 do 1690, t. 1, wyd. E. Rykaczewski, Berlin-Poznań 1864, s. 195). Zob. także niżej przyp. 196. 
przyrodniemu bratu, lecz - zgodnie z prawdą - odnotowano udział Gaudentego w tragicznej misji pruskiej („Sanctus Adalbertus, Pragensis archiepiscopus [sic], Gneznam [...] veniens, fidem catholicam in tota Polonia roboravit et archiepiscopatu iterum in Gnezna relicto ${ }^{38}$, in Prussiam cum fratre suo Gaudentio et Benedicto proficiscitur et ibidem a Cassubis occiditur et martyrio coronatur") ${ }^{39}$. To przeplatanie się obu „koncepcji” odnośnie do roli, jaką przyszło odegrać bł. Radzimowi po wyruszeniu św. Wojciecha do Prus (czy mianowicie towarzyszył mu w owej wyprawie, czy też pozostał w Gnieźnie i jakoby kierował sprawami nieistniejącej wszak wówczas jeszcze archidiecezji gnieźnieńskiej), będzie występować w rozmaitych konfiguracjach w niemal całym uwzględnionym w dalszej naszej analizie piśmiennictwie staropolskim doby nowożytnej, zanim ów nieprawdziwy obraz zostanie ostatecznie wyparty przez opartą na świadectwie źródeł z epoki świadomość z jednej strony mylności przeświadczenia o funkcjonowaniu polskiej prowincji kościelnej jakoby jeszcze przed rokiem 999/1000, z drugiej zaś pewności udziału bł. Radzima-Gaudentego w zakończonej męczeństwem pruskiej misji jego przyrodniego brata.

\section{III.}

W naszym przeglądzie dotarliśmy zatem do XVI stulecia, powszechnie łączonego na płaszczyźnie ojczystych dziejów już nie z wiekami średnimi, lecz z epoką nowożytną. Był to niemniej czas, kiedy średniowieczny obraz świata wciąż dominował w rodzimej kulturze, tylko z lekka przeoranej przez idee odrodzeniowe. Widać to również po zabytkach ówczesnego piśmiennictwa, które nadal sięgały po wypróbowane wzorce, wypracowane w poprzedniej epoce, często świadomie dążąc do zachowania ciągłości. I tak co się tyczy historiografii, wykształcony w Krakowie i Bolonii, a przez całą dekade przebywający w Wiecznym Mieście Bernard Wapowski z Radochoniec (ok. 1450-1535), podjął się kontynuowania Annales Jana Długosza, opracowując kronikę obejmującą dzieje Polski od czasów najdawniejszych aż po rok swej śmierci. Do naszych czasów dotrwała jednakże tylko jej część odnosząca się do okresu od roku 1380, natomiast wcześniejsze partie kronik Wapowskiego, traktujące o całej epoce piastowskiej, uważane są za prawdopodobnie bezpowrotnie zaginione i stąd trudno wskazać, jaką wiedzą na temat bł. Radzima-Gaudentego dysponował ów historiograf z przełomu XV i XVI w ${ }^{40}$.

${ }^{38}$ Słowa „archiepiscopatu iterum in Gnezno relicto” stanowią być może konsekwencję znajmości Annales Jana Długosza, w których św. Wojciech określony został mianem ,archiepiscopus Pragnensis" (zob. wyżej s. $\underline{6}$ ), lub też tylko przeniesienia realiów XVI w., gdy Praga była od dawna stolicą arcybiskupią, na wiek X i uznanie, że ów Sławnikowic był wpierw metropolią praskim, a następnie gnieźnieńskim.

${ }^{39}$ Kronika o Piotrze Właście, wyd. A. Semkowicz, [w:] MPH, t. 3, s. 762. Zob. także Korta, Średniowieczna annalistyka śląka, s. 320-322; Bering, Struktury narracyjne, passim.

${ }^{40}$ Odnośnie do kroniki B. Wapowskiego zob. m.in. S. Grygiel, Próba rekonstrukcji zaginionej części „Kroniki” Bernarda Wapowskiego, „Studia Źródłoznawcze”, 9 (1964) s. 105-115; B. Bieńkowska, Nad „Kronika” Bernarda Wapowskiego, „Studia Źródłoznawcze” 11 (1966), s. 111-126. Także Polska - dzieje i rzeczy jej rozpatrywane przez Joachima Lelewela, t. 1, s. $10 \mathrm{nr}$ 
Odmiennie rzecz przedstawia się $\mathrm{w}$ odniesieniu do należącego do tej samej generacji, co Bernard Wapowski, choć zmarłego o kilkanaście lat wcześniej, Macieja Karpigi z Miechowa (1457-1523), który był autorem pierwszej drukowanej kroniki polskiej. Jako Chronica Polonorum ukazała się ona w roku 1519, a już w dwa lata później doczekała się powtórnego wydania (1521), zaś jej przedruk znalazł się także w monumentalnym zbiorze Poloniae historiae corpus Jana Pistoriusa z roku $1582^{41}$. Ponieważ sięgało do niej w następnych dekadach i wiekach wielu historiografów, stąd też zawarte w niej treści wydatnie przyczyniły się do utrwalenia określonego obrazu rozmaitych faktów z ojczystej przeszłości tudzież wizerunków szeregu postaci. Niestety, w przypadku bł. Radzima-Gaudentego Miechowita okazał się kontynuatorem tradycji upatrującej w nim następcę na gnieźnieńskiej stolicy arcybiskupiej św. Wojciecha. Tak też pisząc o przybyciu późniejszego męczennika do Gniezna, Maciej Karpiga stwierdza: „Illic mortuo Roberto, archiepiscopo Gnesnensi, ad instantissimas preces Myeczyslai principis et filii eius Boleslai cathedram Gnesnensem regendam suscepit. Nec longe post constituto Gaudentio, germano suo, in archiepiscopatu Gneznensis, ad seminandum verbum Dei et fidem Christianam propagandam in Prussiam processit"42. W kontekście zjazdu gnieźnieńskiego i rzekomej koronacji Bolesława Chrobrego Miechowita o Gaudentym nie wspomina ${ }^{43}$, podobnie jak nie podaje daty jego śmierci ${ }^{44}$. Na kartach Chronica Polonorum ówże arcybiskup gnieźnieński pojawia się wszakże raz jeszcze, mianowicie przy opisie najazu na Polskę w r. 1038 księcia czeskiego Brzetysława I, gdzie powtórzona została też wiadomość, że Czesi mieli wówczas uwieźć do Pragi ciało bł. Radzima-Gaudentego jakoby w mylnym przekonaniu, iż jest to ciało jego przyrodniego brata, św. Wojciecha ${ }^{45}$.

XXXIII; J. Szujski, Bernard Wapowski i jego kronika, w: Kroniki Bernarda Wapowskiego z Radochoniec, kantora katedr[alnego] krakowskiego, część ostatnia, czasy podlugoszowskie obejmujaca, (1480-1535), wyd. J. Szujski (Scriptores rerum Polonicarum, t. 2), Kraków 1874, s. V-XXX; HNP, t. 6, s. 724-725; Л. Михаловская, Ян Длугош и Бернард Ваповский. Сравнительная характеристика на материалах истории Белорусии и Литвы, w: Dlugossiana, t. 2, s. 85-93; Stownik historyków polskich, s. 544-545; Grabski, Zarys historii historiografii, s. 31; Dawni pisarze polscy, t. 5, Warszawa 2004, s. 20-22 (I. Teresińska).

${ }^{41}$ O Macieju Karpidze z Miechowa i jego spuściźnie zob. m.in. Polska - dzieje i rzeczy jej rozpatrywane przez Joachima Lelewela, t. 1, s. 9-10 nr XXXII; K. Estreicher, Bibliografia polska, t. 22, Kraków 1908, s. 356-361; L. Hajdukiewicz, Maciej z Miechowa zwany Miechowita (ok. 1457-1523), lekarz, astrolog, geograf, profesor i rektor Akademii Krakowskiej, w: Polski słownik biograficzny [dalej: PSB], t. 19, Wrocław-Warszawa-Kraków-Gdańsk 1974, s. 28-33; Stownik historyków polskich, s. 324-325; Grabski, Zarys historii historiografii, s. 32-33; Dawni pisarze polscy, t. 2, Warszawa 2001, s. 401-402 (I. Teresińska).

${ }^{42}$ Maciej z Miechowa, Chronica Polonorum, Cracoviae 1521 [reprint: Kraków 1986], s. XXXI; Poloniae historiae corpus hoc est Polonicarum rerum latini recentiores et veteres scriptores, t. 2, ed. J. Pistorius, Basileae 1582, s. 25-26.

${ }^{43}$ Maciej z Miechowa, Chronica Polonorum, s. XXXI; Poloniae historiae corpus, t. 2, s. 26.

${ }^{44}$ Por. Maciej z Miechowa, Chronica Polonorum, s. XXXV; Poloniae historiae corpus, t. 2, s. 28 (gdzie o koronacji Mieszka II w r. 1025; jako koronator wymieniony tamże arcybiskup gnieźnieński Hipolit).

${ }^{45}$ Maciej z Miechowa, Chronica Polonorum, XXXVIII; Poloniae historiae corpus, t. 2, 
Kolejnym wielce poważanym historiografem polskim XVI stulecia, na którego powoływało się wielu późniejszych pisarzy rodzimych i obcych, był pochodzący z mieszczańskiej rodziny z Biecza Marcin Kromer (1512-1589), którego pracowity żywot znalazł uwieńczenie w godności pasterza diecezji warmińskiej $(1569 / 1579-1589)^{46}$. W roku 1555 tenże uczony prałat, nobilitowany trzy lata wcześniej przez króla Zygmunta II Augusta, ogłosił drukiem dzieło De origine et rebus gestis Polonorum, które u potomnych zyskało miano „poczytnego” kompendium dziejów Polski. Będąc nieodrodnym synem epoki odrodzenia, odznaczał się Kromer - nie tylko zresztą w swym pisarstwie historycznym - dość znacznym krytycyzmem, co pozwoliło mu odrzucić szereg uznanych w przyszłości przez naukę za nieodpowiadające prawdzie historycznej przekazów. On to właśnie, bawiąc w Pradze z poselstwem do cesarza Ferdynanda I, miał zwrócić uwagę władającemu także w Królestwie Czech monarsze, że ciało św. Wojciecha, którego posiadaniem szczyciła się archikatedra na praskich Hradczanach, z pewnością nie należy do owego męczennika, skoro było ono kompletne, a przecież ramię świeżo co wówczas kanonizowanego biskupa praskiego Bolesław Chrobry ofiarował cesarzowi Ottonowi III, ten zaś przekazał je do Wiecznego Miasta ${ }^{47}$. M. Kromer nie poszedł także za innymi autorami w materii bezzasadnie rozbudowanej chronologii arcybiskupów gnieźnieńskich w X wieku, w której Radzima-Gaudentego umieszczano dopiero na piątym miejscu. Nie dane mu jednak było ustalić, że początki tejże stolicy metropolitalnej sięgają zaledwie lat 999-1000, a nie wcześniejszych czasów, stąd mamy do czynienia u niego z jedynie połowiczną korekturą. Przy opisie panowania Bolesława I Chrobrego (księga III) pisze on mianowicie: „Mortuo illis diebus Roberto, primo Gnesnensi archiepiscopo, [sanctus] Adalbertus magnis principis precibus exoratus, quemadmodum volunt nostrates, sufficiunt. Sed non multo interiecto tempore, viso nocturno divinitus admonitus, iam inde ab initio susceptam ad Prussos [...] peregrinationem, aegre dimittentibus

s. 29-30 („,corpus Gaudencii, archiepiscopi Gneznensis [...], quod Bohemi, pontificalibus indutum, rapuerunt, credentes fore corpus beatissimi praesulis Adalberti").

${ }^{46}$ Zob. m.in. Polska - dzieje i rzeczy jej rozpatrywane przez Joachima Lelewela, t. 1, s. 11 nr XXXIX; Estreicher, Bibliografia polska, t. 20, Kraków 1905, s. 276-287; H. Barycz, Kromer Marcin herbu własnego (1512-1589), biskup warmiński, dyplomata, historyk, pisarz kontrreformacyjny, PSB, t. 15, s. 319-325; Barycz, Szlakami dziejopisarstwa staropolskiego, s. 71-130; Stownik polskich teologów katolickich [dalej: SPTK], t. 2, red. H. E. Wyczawski, Warszawa 1982, s. 429-436 (H. E. Wyczawski); Stownik historyków polskich, s. 265-266; Grabski, Zarys historii historiografii, s. 32; Dawni pisarze polscy, t. 2, s. 277-280 (I. Teresińska).

${ }^{47}$ Zob. F. Jaroszewicz, Matka świętych Polska albo żywoty świętych, blogosławionych, wielebnych, światobliwych, pobożnych Polaków i Polek wszelkiego stanu i kondycyi, każdego wieku, od zakrzewioney w Polszcze chrześcijańskiey wiary osobliwa życia doskonałościa stynących, z różnych autorow y pism, tak polskich, iako y cudzoziemskich, zebrane y spisane [...], Kraków 1767, s. 276 (także XIX-wieczne wydanie: F. Jaroszewicz, Matka świętych Polska albo żywoty świętych, błogostawionych, wielebnych, świątobliwych, pobożnych Polaków i Polek wszelkiego stanu i kondycyi, każdego wieku, od zakrzewioney w Polszcze chrześcijańskiey wiary osobliwa życia doskonatościa stynacych, z różnych autorow y pism, tak polskich, iako y cudzoziemskich, zebrane y spisane przez X. Floryana Jaroszewicza, kapłana zakonu Ś. O. Franciszka reformatów, dla zbudowania żyjacych i potomnych, dla pociechy duchownej swoich krewnych, t. 2, Piekary Śląskie 1850, s. 333-334). 
eum principibus, persequitur, relicto pro se Gaudentio, sive Razino, fratre, archiepiscopo"48. A zatem nawet dość krytycznemu Kromerowi nie udało się wyrwać $\mathrm{z}$,zaklętego kręgu” powtarzanych w kolejnych zabytkach piśmiennictwa staropolskiego wiadomości o rzekomym objęciu wpierw przez św. Wojciecha rządów w archidiecezji gnieźnieńskiej, a następnie złożeniu ich przed wyruszeniem do Prus w ręce bł. Radzima-Gaudentego, którego osobisty udział w tragicznie zakończonej wyprawie misyjnej i przez tego historiografa pozostał niedostrzeżony. Autorytet Długosza i Miechowity, wsparty innymi jeszcze świadectwami, o których była wyżej mowa, okazał się więc w owej materii niepodważalny. Prócz tego Marcin Kromer nie omieszkał też wspomnieć na temat interesującej nas postaci przy opisie najazdu Czechów na Polskę w roku 1038, notując w księdze IV, iż grabieżcy „Gaudentii corpus, pro Adalberti corpore a ministris templi pio mendacio indicatum, etiam tollunt. Nam Adalberti corpus iidem ministri in adito templi clam defoderant" ${ }^{\prime 9}$.

Prócz powyższego M. Kromer bodaj jako pierwszy wprowadził do polskiego piśmiennictwa historycznego (a w dalszej kolejności też hagiograficznego) nowy szczegół w curriculum vitae Radzima-Gaudentego, który nie występuje u piszących przed nim autorów. Opierając się na świeżo co wydanym w roku 1552 w Prostějowie dziele Historia Regni Bohemiae Jana Dubraviusa (Jan Skála z Doubravky, w latach 1541-1553 biskup ołomuniecki, nota bene blisko z Polską związany i konsekrowany 2 I 1542 przez sufragana krakowskiego Dominika Małachowskiego), wskazał on na bezpośredni związek przybycia do Polski eremitów, zwanych później Pięcioma Braćmi Męczennikami, właśnie z faktem sprawowania godności arcybiskupiej w Gnieźnie przez brata św. Wojciecha. Według Dubraviusa przedtem czynni byli oni (tj. Mateusz, Benedykt, Jan, Izaak i Krystian oraz szósty Barnaba, któremu zaoszczędzona została śmierć męczeńska) w Czechach, i właśnie stamtąd, już po nastaniu rządów Radzima-Gaudentego w Kościele gnieźnieńskim, mieli się tu przenieść, dzięki niemu zyskując w nowym miejscu swego pobytu odpowiednie warunki dla dalszego realizowania obranego charyzmatu $^{50}$. Marcin Kromer wiadomość tę przytacza, wszakże w pewnej mierze dystansuje się względem niej, wskazując, iż odnośna relacja nie zgadza się z tym, co na ów temat widnieje u Długosza ${ }^{51}$.

${ }^{48}$ Martini Cromeri De origine et rebus gestis Polonorum libri XXX, Basileae 1555, s. 52 (gwoli ścisłości jest to druga już wzmianka o Radzimie-Gaudentym u M. Kromera, nieco wcześniej bowiem wspomina on o nim, jako o towarzyszu św. Wojciecha w podróży na Węgry: „[Sanctus Adalbertus] in Ungariam, Razino sive Gaudentio fratre et viris aliquot religiosis comitantibus, profectus erat"); Poloniae historiae corpus, t. 2, s. 437; Kronika polska Marcina Kromera, biskupa warmińskiego, ksiag XXX, dotad $w$ trzech językach, a mianowicie w tacińskim, polskim i niemieckim wydana, na język polski z łacińskiego przełożona przez Marcina z Błażowa Błażowskiego [...], Sanok 1857, s. 109.

${ }^{49}$ Martini Cromeri De origine et rebus gestis Polonorum libri XXX, s. 71; Poloniae historiae corpus, t. 2, s. 449; Kronika polska Marcina Kromera, s. 147.

${ }^{50}$ Joannis Dubravii, Olomuzensis episcopi, Historia Bohemica, Francofurti 1687, s. 159 (także wcześniejsze wydania).

${ }^{51}$ Kronika polska Marcina Kromera, s. 123. Zob. nadto Hagiografia polska, t. 2, s. 234-247 (J. Mitkowski); H. Fros, F. Sowa, Księga imion i świętych, t. 1, Kraków 1997, kol. 400-403; Nasi święci. 
W roku 1562 ukazało się drukiem w Krakowie niepokaźne dziełko Stanisława Orzechowskiego (1513-1566) Chimera sive de Stancari funesta Regno Poloniae secta, po którego tytule zgoła trudno by było odgadnąć, że i w nim znajdziemy jakieś informacje o początkach organizacji diecezjalnej na ziemiach polskich. Podejmując ów wątek, Orzechowski nie zdobył się wszakże na jakieś samodzielne rozważania i oryginalne konkluzje, lecz za Janem Długoszem powtórzył dobrze nam znaną wesję o dwóch arcybiskupstwach oraz siedmiu biskupstwach za czasów Mieszka I i w ślad za tamtym dziejopisem przytoczył też imiona owych rzekomych pierwszych arcybiskupów oraz biskupów Kościoła polskiego (w przypadku stolicy metropolitalnej w Gnieźnie jest to Vilibalmus, a w konsekwencji o bł. Radzimie-Gaudentym nie ma u tego autora ani słowa wzmianki) ${ }^{52}$. Nie inaczej postąpił współczesny poprzedniemu kasztelan sanocki Jan Herburt (po 1524-1577) w wydanej w r. 1571 w szwajcarskiej Bazylei kompilacji zatytułowanej Chronica sive historiae Polonicae compendiosae ac per certa librorum capita ad facilem memoriam recens facta descriptio. W jej księdze II, w rozdziale De Miecislao Primo, pisze on o księciu Mieszku I, że po przyjęciu chrztu „basilicas novem, diversis locis, aedificat easque supellectili omnis generis pretiosa ornat, censibus et possessionibus locupletat, et in dioeceses distributas, duas quidem ex his archiepiscopis, nempe Gnesnensem et Cracoviensem, reliquas vero, hoc est Posnaniensem, Smorogoviensem (quae postea Bicinensis ac demum Vratislaviensis dicta est), Crusviciensem, Plocensem, Culmensem, Lubuscensem et Camenecensem [sic], singulis episcopis attribuit eisque decimas omnis generis frugum [...] adscribit. His autem rebus perficiendis Aegidius cardinalis, episcopus Tusculanus, Joannis XIII. Pontificix Maximi legatus, praefuit; qui primus archiepiscopos et episcopos Italici ac quandam Gallici et Germanici generis, fecit; quum

Polski słownik hagiograficzny, red. A. Witkowska, Poznań 1999, s. 438-449 (J. Mitkowski). Por. M. Derwich, Benedyktyński klasztor Św. Krzyża na Łysej Górze w średniowieczu, Warszawa-Wrocław 1992, s. 266, gdzie wskazanie na analogiczne ujęcie zagadnienia w powstałych na początku XVI w., prawdopodobnie we Wrocławiu, rękopiśmiennych Quaedam memorabilia, wedle których za czasów arcybiskupa Gaudentego przybyło do Polski z Brzewnowa sześciu mnichów (benedyktynów), których wcześniej osadził tam św. Wojciech, przywiódłszy ze sobą z Rzymu. - Zapiski historyczne odnoszące się do dziejów Polski, Szląska i Czech, wyd. A. Semkowicz, MPH, t. 3, s. 741: „Circa idem tempus, scilicet post occisionem sancti Adalberti, Gaudentius, frater sancti Adalberti, eiusdem Ordinis [Sancti Benedicti], susceptus est in archiepiscopum Gnesnensem. Cuius gratia sex fratres, quos sanctus Adalbertus secum ex Urbe duxerat, de monasterio Brunawo ad ipsum Gaudentium venerunt de licentia sui abbatis Anastasii”. Odnośnie do wiarogodności tego świadectwa zob. G. Labuda, Radzim, czes. Radim, tac. Gaudenty, pierwszy arcybiskup polski w Gnieźnie, w: Słownik starożytności słowiańskich, t. 4, red. G. Labuda i Z. Stieber, Wrocław-Warszawa-Kraków 1970, s. 457; nadto W. Korta, Średniowieczna annalistyka śląska, passim (zwł. s. 326-330); P. Vlček, P. Sommer, D. Foltýn, Encyklopedie českých klášterů, Praha 1998, s. 596-597.

${ }^{52}$ Stanislai Orichovii Roxolani Chimera sive de Stancari funesta Regno Poloniae secta, [Cracoviae] 1562, k. 89v-90v. Odnośnie do osoby autora zob. m.in.: K. Estreicher, Bibliografia polska, t. 23, Kraków 1910, s. 444-460; [Red.] Orzechowski Stanisław herbu Oksza (1513-1566), ksiadz, pisarz polityczny i polemista religijny, PSB, t. 24, s. 287-292; SPTK, t. 3, red. H. E. Wyczawski, Warszawa 1982, s. 265-271 (H. E. Wyczawski); Słownik historyków polskich, s. 383384; Dawni pisarze polscy, t. 3, Warszawa 2002, s. 188-191 (I. Teresińska). 
nostri rudes adhuc essent ac novicii" ${ }^{53}$. W kolejnym z rozdziałów tejże księgi (De Boleslao Primo) mowa jest znów m.in. o św. Wojciechu i jego wyprawie misyjnej do Prus, w którym to kontekście J. Herburt wspomina również, że „mortuo illis diebus Roberto, primo Gneznensi archiepiscopo, [sanctus Adalbertus] magnis principis precibus exoratus, in archiepiscopatu successit. Sed non multo interiecto tempore, visu nocturno divinitus admonitio, peregrinationem in Prussiam persequitur, Gaudentio fratre, sive Rasino, relicto pro se archiepiscopo"54. Osoba bł. Radzima-Gaudentego pojawia się w kronice Jana Herburta raz jeszcze, mianowicie w opisie pielgrzymki cesarza Ottona III do Gniezna. Pisząc o jego spotkaniu z księciem Bolesławem Chrobrym cytowany autor stwierdza w odniesieniu do młodego władcy Świętego Cesarstwa Rzymskiego Narodu Niemieckiego, iż „volens autem tam splendido hospiti et amico parem referre gratiam, regem eum appellat sociumque et amicum Romanii Imperii, a tributo et omni iurisdictione imperatorum immunem, ac diadema suum, Gaudentio archiepiscopo solennes cerimonias peragente, ipsi imponit"55.

W tym samym roku 1582, co wspomniany wcześniej zbiór Poloniae historiae corpus J. Pistoriusa, ukazało się również pierwsze wydanie Kroniki polskiej, litewskiej, żmudzkiej i wszytkiej Rusi pochodzącego z ziemi łęczyckiej kanonika katedralnego żmudzkiego Macieja Stryjowskiego (1547-ok. 1590), zarazem poety. Autor ten, rozwodząc się nad początkami organizacji diecezjalnej w Polsce wczesnopiastowskiej, o bł. Radzimie-Gaudentym w ogóle wszakże nie wspomniał, pisząc za to, że „pierwszym arcybiskupem gnieźnieńskim był Wilibalmus”, drugie arcybiskupstwo sytuując dla tego czasu w Krakowie, a w przypadku pozostałych diecezji również okazując taki sam, co i jego poprzednicy w dziele opisywania ojczystych dziejów, brak orientacji w materii chronologii erygowania kolejnych biskupstw na ziemiach polskich ${ }^{56}$. Postać bł. Radzima-Gaudentego dostrzegł natomiast inny XVI-wieczny historiograf i poeta Marcin Bielski (ok. 1495-1575),

${ }^{53}$ Chronica sive historiae Polonicae compendiosae ac per certa librorum capita ad facilem memoriam recens facta descriptio, authoritate Magnifico viro Joanne Herburto de Fulstin, Regni Poloniae senatore, Basileae 1571, s. 17-18. W przedmiocie życia i dokonać J. Herburta- m.in. Polska - dzieje i rzeczy jej rozpatrywane przez Joachima Lelewela, t. 1, $12 \mathrm{nr}$ XLI; Estreicher, Bibliografia polska, t. 18, Kraków 1901, s. 129-133; R. Żelewski, Herburt Jan herbu własnego (po 1524-1577), kasztelan sanocki, prawnik $i$ historyk, PSB, t. 9, s. 440-442; HNP, t. 6, s. 225-226.

${ }^{54}$ Chronica sive historiae Polonicae compendiosae ac per certa librorum capita ad facilem memoriam recens facta descriptio, s. 20.

${ }^{55}$ Tamże, s. 21.

${ }^{56}$ Kronika polska, litewska, żmodzka y wszystkiey Rusi Kijowskiey, Moskiewskiey, Siewierskiey, Wothińskiey, Podolskiey, Podgorskiey, Podlaskiey, etc. y rozmaite przypadki woienne y domowe pruskich, mazowieckich, pomorskich y inszych krain Krolestwu Polskiemy y Wielkiemu Xięstwu Litewskiemu podlegtych [...] przez Macieia Osostewiciusa Stryikowskiego dostatecznie napisana, złożona y na pierwsze swiatto [...] nowo wydźwigniona przez wszystki starożytne wieki aż do dziesiejszego roku 1582, Królewiec 1582, s. 151; Kronika polska, litewska, żmudzka i wszystkiej Rusi Macieja Stryjowskiego. Wydanie nowe, będące dokładnym powtórzeniem wydania pierwotnego królewieckiego z roku 1582 [...], t. 1, wyd. M. Malinowski, Warszawa 1846, s. 140-141. Odnośnie do osoby autora - m.in.: Polska-dzieje i rzeczy jej rozpatrywane przez Joachima Lelewela, t. 1, s. $12 \mathrm{nr}$ XLII; Stownik historyków polskich, s. 499; Dawni pisarze polscy, t. 4, s. 166-168 (I. Teresińska). 
który nad swą Kronika wszystkiego świata pracował mniej więcej w tym samym czasie, co Marcin Kromer nad De origine et rebus gestis Polonorum. Wydana po raz pierwszy w roku 1551, doczekała się ona później uzupełnienia i nowej edycji w roku 1597 za sprawą jego syna Joachima Bielskiego (ok. 1550-1599) ${ }^{57}$. W dziele tym, prócz poniekąd stałego już elementu curriculum vitae interesującego nas hierarchy, jakim stała się opowieść o przekazaniu rządów w archidiecezji gnieźnieńskiej Gaudentemu przez św. Wojciecha (nawet bez zaznaczenia, iż to bracia) ${ }^{58}$, odnotowana też została jego śmierć w roku $1006^{59}$ i uwiezienie w r. 1038 doczesnych szczątków z Gniezna do Pragi ${ }^{60}$. Interesujący nas hierarcha wspomniany został nadto przez M. Bielskiego jako ten, który dokonał pomazania Bolesława Chrobrego podczas obrzędu królewskiej koronacji ${ }^{61}$, co się natomiast tyczy pierwocin organizacji diecezjalnej na ziemiach polskich, to i ów autor odnosi ją do czasów Mieszka I ${ }^{62}$. Pisze mianowicie, że ten to władca „wnet kościoły zakładał [...], arcybiskupy ustawiał, iednego w Gnieźnie, drugiego w Krakowie. [...] Drugie biskupstwa założył w Poznaniu y w Smogorzowie abo Byczynie (bo tak pierwey zwano), które stąd przeniesiono do Wrocławia, potym w Kruszficy, które z czasem przeniesiono do Włocsławka [sic] nad Wisłą, płockie, chełmieńskie, lubuskie y kamienieckie [sic]"63. Nieco niżej dodaje wszakże, iż według niego wątpliwym wydaje się, ,aby chełmińskie biskupstwo y płocki na ten czas od Mieszka były ustanowione, lecz potem [tj. później], gdyż pod ten czas w cheł-

${ }^{57} \mathrm{Na}$ temat obu Bielskich zob. m.in. Polska - dzieje i rzeczy jej rozpatrywane przez Joachima Lelewela, t. 1, $11 \mathrm{nr}$ XXXVIII, s. $13 \mathrm{nr}$ XLV; Estreicher, Bibliografia polska, t. 13, Kraków 1894, s. 81-83, 84-90; H. Barycz, Bielski Joachim († 1599), poeta i historyk, PSB, t. 2, s. 61-64; I. Chrzanowski, Bielski (pierwotne nazwisko: Wolski) Marcin herbu Prawdzic (1495-1575), rycerz i ziemianin, kronikarz i poeta, PSB, s. 64-66; Stownik historyków polskich, s. 42-43; Dawni pisarze polscy, t. 1, s. 65-68; Grabski, Zarys historii historiografii, s. 36, 40.

${ }^{58}$ Kronika polska Marcina Bielskiego nowo przez Ioach[ima] Bielskiego, syna iego, wydana, Kraków 1597, s. 53 (zob. także s. 52: „Szedł tedy [święty Wojciech] do Rzyma, a tam w klasztorze św. Bonifacyusza mieszkał siedem [sic] lat z towarzyszem swoim Gaudencyusem"); Kronika polska Marcina Bielskiego, t. 1, wyd. K. J. Turowski, Sanok 1856, s. 72-73: „Gdy umarł Robertus, arcybiskup gnieźnieński, na jego miejsce św. Wojciech był obran roku Pańskiego 996. Ale niedługo tu pobywszy, z papieskiego rozkazu szedł do Prus nauczać wiary chrześcijańskiej, zostawiwszy na swoim miejscu Gaudencyusza, towarzysza swego, który był także Różyc”.

${ }^{59}$ Kronika polska Marcina Bielskiego nowo przez Ioach[ima] Bielskiego, syna iego, wydana, s. 60; Kronika polska Marcina Bielskiego, t. 1, s. 85: „Roku 1006 po Gaudencyusie był wzięt na arcybiskupstwo gnieźnieńskie Hippolytus Włoch".

${ }^{60}$ Kronika polska Marcina Bielskiego nowo przez Ioach[ima] Bielskiego, syna iego, wydana, s. 69; Kronika polska Marcina Bielskiego, t. 1, s. 102.

${ }^{61}$ [M. Bielski], Kronika tho iesth historya swiata na sześć wiekow a cztery monarchie rozdzielona, z rozmaitych historykow [...] wybierana y na polski ięzyk wypisana [...], od początku swiata $a \dot{z}$ do tego roku, ktory się pisze 1564 [...], Kraków 1564, k. 344v („,cesarz Otto koronował go thamze [w Gnieźnie] w kościele na Polskie Krolestwo, przy arcybiskupie gnieźnieńskim Gaudencyusie, który go pomazał").

${ }^{62}$ Tamże, k. 344r. Zob. także następne przypisy.

${ }^{63}$ Kronika polska Marcina Bielskiego nowo przez Ioach[ima] Bielskiego, syna iego, wydana, s. $49-51$. 
mieńskim kraju ieszcze Prusowie pogani panowali” ${ }^{{ }^{4}}$. Zwraca też Bielski uwagę, że ,pisze ieden stary Anonimos, iż nie zrazu arcybiskupa w Krakowie, lecz biskupa pierwej fundowano, a naprzód miałby tu być arcybiskupem Aaron, opat tyniecki, za mnicha Kazimierza [tj. księcia Kazimierza I Odnowiciela], po którym też rychło tego drudzy zaniedbali” ${ }^{\prime 65}$. Nie przeszkodziło mu to wszakże przytoczyć widniejące u Dłogosza imiona rzekomych pierwszych arcybiskupów i biskupów w państwie Piastów (w przypadku Gniezna chodzi oczywiście o „Vilibalmusa Francuza"), tudzież dodać, że dla ukonstytuowania owej wyimaginowanej hierarchii ,przyjechał do Polski ustanawiać biskupy kardynał Egidius, biskup tuskulański” (wyraziwszy zresztą przy tym wątpliwości: „niewiedzieć ieśli poń posłano, czy-li sam papież Jan XIII rozkazał mu tu przyjechać") ${ }^{66}$.

Osoba młodszego z dwóch piastujących godności biskupie synów Sławnika pojawia się także na kartach niezwykle poczytnych i po wielokroć wznawianych - po czasy nam współczesne włącznie - Żywotów świętych Starego i Nowego Zakonu słynnego kaznodziei i pisarza, jezuity Piotra Skargi (1536-1612), po raz pierwszy wydanych drukiem w roku $1579^{67}$. Bł. Radzim-Gaudenty nie doczeka1 się tam wprawdzie osobnego życiorysu, tym niemniej wspomina się o nim w opisie losów św. Wojciecha. W odniesieniu do tego ostatniego autor omawianego dzieła stwierdza, że „Bolesław, książę polski, papieża prosił, aby mu [go] za arcybiskupa do Gniezna dał - w ten czas, gdy stolica po Robercie, pierwszym arcybiskupie, osierociała" ${ }^{68}$. Wbrew natomiast ugruntowanej już wówczas w piśmiennictwie polskim tradycji, w Radzimie-Gaudentym widzi Piotr Skarga uczestnika owej tragicznej wyprawy misyjnej w roku 997, stąd też czytamy u niego, że wyruszając do Prus „dwu z sobą towarzyszów wziął kapłanów Wojciech, św. Gaudencyusza i drugiego" $"$. Co się tyczy natomiast czasu oraz okoliczności wyniesienia młodszego ze Sławnikowiców na stolicę metropolitalną w Gnieźnie, to autor Żywotów świętych wątku tego w zasadzie w ogóle nie porusza i zgoła można by nawet zastanawiać się, czy godność arcybiskupia Radzima-Gaudentego była mu wiadomą, gdyby nie pojedyncze zdanie z omawianego życiorysu, odnoszące się do

${ }^{64}$ Tamże, s. 51.

${ }^{65}$ Tamże.

${ }^{66}$ Tamże, s. 50-51.

${ }^{67}$ Zob. m.in. Estreicher, Bibliografia polska, t. 28, Kraków 1930, s. 132-170; HNP, t. 6, s. 619-620; SPTK, t. 4, s. 84-92 (L. Grzebień); J. Tazbir, Skarga Piotr (1536-1612), jezuita, polemista religijny, hagiograf, nadworny kaznodzieja Zygmunta III, PSB, t. 38, s. 35-43; Dawni pisarze polscy, t. 4, Warszawa 2003, s. 73-76 (I. Teresińska); Encyklopedia wiedzy o jezuitach na ziemiach Polski i Litwy 1564-1995, oprac. L. Grzebienia 2004², s. 619-620.

${ }^{68}$ Żywoty swiętych Starego y Nowego Zakonu na każdy dzień przez caty rok, wybrane z doktorów kościelnych, których imiona na wyzszey sa położone [...], przez księdza Piotra Skarge, Societatis Jesu, przebrane, uczynione i w ięzyk polski przełożone, Wilno 1579, s. 355 (całość życiorysu św. Wojciecha - s. 352-358). Z późniejszych wydań zob. przykładowo: P. Skarga, Żywotów świętych Starego i Nowego Zakonu, na każdy dzień przez cały rok, wybranych z poważnych pisarzów i doktorów kościelnych, których imiona wyżej sa położone, część pierwsza [...], wyd. K. Maniewski, Wiedeń 1860, s. 285.

${ }^{69}$ Żywoty swiętych Starego y Nowego Zakonu na każdy dzień, s. 355; Skarga, Żywotów świętych Starego i Nowego Zakonu [...] część pierwsza [...], s. 285. Zob. także niżej przyp. 163. 
wydarzeń roku 1000 i zjazdu w Gnieźnie, gdzie czytamy, że „Bolesław [Chrobry] koroną królewską od cesarza [Ottona] uczczony i koronowany [został] w tymże kościele [gnieźnieńskim] przez ucznia św. Wojciecha, Gaudencyusza, który był na jego miejsce nastąpił"70.

W świetle przytoczonych tu cytatów jest dla nas jasne, iż również dla Piotra Skargi stanowiło rzecz oczywistą, że arcybiskupstwo w Gnieźnie funkcjonowało już na długo przed rokiem 1000. Zresztą przecież to on właśnie był autorem polskiego przekładu słynnych Annales ecclesiastici a Christo nato ad annum 1198 kardynała Cesare Baroniusza (1538-1607), dokonanego zresztą w formie wyboru z obszerniejszego oryginału ${ }^{71}$. W odróżnieniu też od tamtego, który doprowadzony został po początek przełomowego pontyfikatu papieża Innocentego III (1198), edycja Skargi obejmuje okres od narodzenia Chrystusa tylko po rok 1000 włącznie. Nie mogło jednak w niej zabraknąć i polskich „akcentów”, poczynając od chrztu Polski, o którym czytamy pod rokiem 965 (z powołaniem przede wszystkim na Kromera, a także Orzechowskiego $)^{72}$. Jest w owym kontekście mowa także o misji do państwa Mieszka I biskupa tuskulańskiego Idziego (Egidiusza), jako legata papieża Jana XIII, ani słowem wszakże nie wspomina się przy tym o utworzeniu tu jakoby już wówczas stałej organizacji diecezjalnej, co też późniejsi dziejopisarze staropolscy nie omieszkali wytknąć Baroniuszowi, jako rzekomą sprzeczność, dla nich bowiem jawiło się czymś oczywistym, że celem rzeczonej legacji było właśnie ustanowienie w Polsce stolic biskupich $\mathrm{i}$ ich obsadzenie. Tymczasem w Rocznych dziejach kościelnych o momencie tudzież okolicznościach erygowania pierwszych polskich diecezji w ogóle mowy nie ma, co się natomiast tyczy samej metropolii gnieźnieńskiej, to pod rokiem 999 czytamy, że „o przyjachaniu Ottona cesarza do Gniezna, do ciała św. Wojciecha męczennika, wspomina Ditmarus, y to iakoby cesarz Gnieznu arcybiskupią godność dał, y jako go Bolesław ksiażę uczcił y udarował. O czym się też przyszłego roku wspomni. Nie cesarski to był urząd arcybiskupią dostoyność dawać; musiał przy nim być poseł papieski, ktory to mógł uczynić. A też się z listu papieża Grzegorza VII pokazuje, iż Polska arcybiskupa nie miała aż do roku Pańskiego 1074. O co się ten Grzegorz VII frasuje, iż biskupi szerokie barzo biskupstwa maiąc, dosyć im czynić nie mogą, a iż bez arcybiskupa w rządzie swoim nie stoią"73. A zatem według Baroniusza arcybiskupstwo w Gnieźnie miało powstać dopiero za panowania w Polsce Bolesława II Szczodrego vel Śmiałego, stąd też pod rokiem 1000 (zamykającym - jak już zaznaczono - Roczne dzieje kościelne) nic o utworzeniu polskiej metropolii nie wspomina, zaś opis zjazdu gnieźnieńskiego sprowadza się tam w zasadzie do pojedynczego ledwie zdania, natomiast główny akcent poło-

${ }^{70}$ Żywoty swiętych Starego y Nowego Zakonu na każdy dzień, s. 357; Skarga, Żywotów świętych Starego i Nowego Zakonu [...] część pierwsza [...], s. 286.

${ }^{71}$ Roczne dzieje kościelne od narodzenia Pana y Boga naszego Jesusa Christusa, wybrane z rocznych dziejów kościelnych Cesara Baroniusza, kardynała Świętego Rzymskiego Kościoła, nazwanych "Annales ecclesiastici», przez X. Piotra Skargę, Societatis Jesu, z dozwoleniem tegoż kardynała y starszych. Te księgi zamykaja w sobie dziesięć tomów, to iest lat tysiąc, Kraków 1603.

${ }^{72}$ Tamże, s. 995.

${ }^{73}$ Tamże, s. 1010-1011. 
żony został na zagadnienie zabrania przez cesarza Ottona III z Gniezna cząstki relikwii św. Wojciecha i jej przekazania następnie do Wiecznego Miasta, którym to faktom piszący z rzymskiej perspektywy autor poświęcił nieporównanie wiecej uwagi $^{74}$. Co się tyczy z kolei samego Radzima-Gaudentego, to jego imię w omawianej edycji ani razu się nie pojawia, choć o św. Wojciechu mowa jest tam kilkakrotnie, mianowicie w odniesieniu do lat 980, 989 (gdzie o wyprawie na Węgry) oraz 997 (tu oczywiście o męczeństwie) ${ }^{75}$.

Tak samo wyłącznie o starszym ze Sławnikowiców pisze w wydanych po raz pierwszy w roku 1587 w Krakowie Annales sive de origine et rebus gestis Polonorum et Litvanorum libri octo Stanisław Sarnicki (ok. 1532-1597) ${ }^{76}$. W księdze VI rzeczonego dzieła (rozdział Boleslaus Chrobri) zawarty jest mianowicie obszerny passus (w XVIII-wiecznym wydaniu opatrzony nawet nagłowkiem De sancto Adalberto), w którym autor ów - co może do pewnego stopnia zaskakiwać - nie przypisuje późniejszemu męczennikowi godności arcybiskupa gnieźnieńskiego, a w konsekwencji nie ma też mowy tamże o ustąpieniu z niej przezeń na korzyść młodszego brata. O bł. Radzimie-Gaudentym nie wspomniano również w kontekście pielgrzymki do Gniezna cesarza Ottona III, choć nie zabrakło tu wiadomości o rzekomej koronacji Bolesława I Chrobrego, podobnie jak nie pisze S. Sarnicki czegokolwiek w ogóle na temat początków organizacji diecezjalnej na ziemiach polskich ${ }^{77}$. Tym samym trudno stwierdzić, czy zapatrywania rzeczonego autora w owej materii czymś się różniły w stosunku do tego, co na ów temat utrzymywali inni współcześni mu historiografowie staropolscy, czy też jedynie tematykę tą z sobie wiadomych względów całkowicie pominął na kartach Annales sive de origine et rebus gestis Polonorum et Litvanorum, co zapewne łączyć należy z faktem, że był on kalwinem i zagorzałym polemistą antykatolickim, stąd rozpisywanie się na temat fundacji biskupstw w Polsce z nietrudnych do odgadnięcia powodów mógł uważać za w najlepszym razie zbyteczne.

Przy omawianiu XVI-wiecznego piśmiennictwa polskiego pod kątem obecności w nim postaci bł. Radzima-Gaudentego nie sposób nie wspomnieć o bodaj pierwszym w rodzimej historiografii drukowanym herbarzu, mianowicie Herbach rycerstwa polskiego na pięcioro xiag rozdzielonych Bartosza Paprockiego (ok. 1543-1614), wydanym w roku 1584 . W rozdziale O klejnocie Róża, opierając się - o czym sam wspomina - na kronice Macieja Karpigi z Miechowa oraz katalogu

${ }^{74}$ Tamże, s. 1012.

${ }^{75}$ Tamże, s. 999, 1002, 1007-1008.

${ }^{76}$ Stanislai Sarnicii Annales sive de origine et rebus gestis Polonorum et Litvanorum libri octo [...], Cracoviae 1587; Stanislai Sarnicii Annales sive de origine et rebus gestis Polonorum et Litvanorum libri VIII [...], [w:] Joannis Dlugossi seu Longini Historiae Polonicae tomus secundus, Lipsiae 1712, kol. 827-1232. Odnośnie do osoby autora zob. m.in.: Polska - dzieje i rzeczy jej rozpatrywane przez Joachima Lelewela, t. 1, s. 12-13 nr XLIII; K. Estreicher, Bibliografia polska, t. 27, Kraków 1929, s. 140-150; HNP, t. 6, s. 590-591; H. Kowalska, J. Sikorski, Sarnicki Stanisław herbu Ślepowron (1532-1597), minister i polemista kalwiński, historyk, wojski krasnostawski, PSB, t. 35, s. 217-233; Stownik historyków polskich, s. 463; Grabski, Zarys historii historiografii, s. 34-35; Dawni pisarze polscy, t. 4, s. 20-22 (I. Teresińska).

${ }^{77}$ Stanislai Sarnicii Annales, s. 224-226 (w wydaniu z roku 1712 - s. 1048-1050). 
arcybiskupów gnieźnieńskich, rzeczony autor przedstawił pokrótce losy zarówno św. Wojciecha, jak i jego przyrodniego brata, pisząc m.in. o ich wspólnym pobycie w klasztorze św. Aleksego w Rzymie i późniejszym przybyciu poprzez Węgry do Polski. Bazując na wyżej wspomnianych źródłach, nieuchronnie powtórzył też za nimi wiadomość o osadzeniu Radzima-Gaudentego na stolicy metropolitalnej w Gnieźnie przez zamierzającego wyruszyć z misją do Prus jego brata, którego również umieszcza w poczcie arcypasterzy Kościoła gnieźnieńskiego ${ }^{78}$. O tym wzmiankuje Paprocki zarówno w curriculum vitae św. Wojciecha, jak i w osobnej, zwięzłej nocie o młodszym z obdarzonych infułami Sławnikowiców, która ma brzmienie: „Gaudencyus, brat [Wojciecha] rodzony [sic], jak to katalog opowieda, jeszcze za żywota jego był arcybiskupem gnieźnieńskim, na którym żył lat siedem, wiodąc także żywot świątobliwy. Umarł w roku 1006; w Gnieźnie pochowan. [...] O tym Gaudencyusie pisał Klemens Janicki te wiersze:

Cessit Adalbertus, frater Gaudencius orbum

Suscepit, vivo fratre iubente, gregem.

Germano similis, similis solet esse colore,

Ex uno funerit quae rosa nata rubo ${ }^{79}$.

Przytoczony tu przez B. Paprockiego fragment poezji łacińskiej Klemensa Janickiego vel Janicjusza (1516-1543), to jeden z passusów jego poetyckiego katalogu arcybiskupów gnieźnieńskich, powstałego w latach 1536-1537, gdy autor pełnił obowiązki sekretarza prymasa Andrzeja Krzyckiego (też zresztą poety). Ów zabytek renesansowego piśmiennictwa trudno wszakże uznać za przejaw twórczości sensu stricto historiograficznej, choć z drugiej strony lektura całości utworu nie pozostawia wątpliwości, że Janicki nie omieszkał zawrzeć w nim przybranych w szatę poezji informacji znalezionych w starszej daty źródłach, przede wszystkim we wcześniejszych katalogach arcybiskupów Gniezna ${ }^{80}$.

Przebywający przez przeszło dwa dziesięciolecia de facto na wygnaniu na Morawach i w Czechach Bartosz Paprocki, który dopiero na cztery lata przed śmiercią wrócił do Polski ${ }^{81}$, za pobytu na ziemiach Korony św. Wacława zapisał się

${ }^{78}$ Herby rycerztwa polskiego na pięcioro xiag rozdzielone, przez Bartosza Paprockiego zebrane y wydane roku Pańskiego 1584, Kraków 1584, s. 356-357; Herby rycerstwa polskiego przez Bartłomieja Paprockiego zebrane i wydane r. 1584, wyd. K. J. Turowski, Kraków 1858, s. 456-457 .

${ }^{79}$ Herby rycerztwa polskiego na pięcioro xiag rozdzielone..., s. 357-358; Herby rycerstwa polskiego przez Bartlomieja Paprockiego..., s. 458.

${ }^{80}$ Rzeczony katalog K. Janickiego doczekał się też thumaczenia na język polski, dokonanego przez P. Schmutzera i M. Jezierskiego (Żywoty arcybiskupów gnieźnieńskich, w: K. Janicki, Utwory tacińskie, wyd. M. Jezierski, Lwów 1933, s. 217-228), w którym ów passus o Radzimie (s. 218-219 $\mathrm{nr} \mathrm{V})$ ma następujące brzmienie:

„Zszedł Wojciech ze świata, a po jego zgonie

Brat Gaudenty wziął rządy wiernych dusz w swe dłonie.

Tak podobny do brata, jak podobna róża

Drugiej, co z nią w czerwieni tej samej się nurza".

${ }^{81} \mathrm{O}$ losach życiowych i spuściźnie B. Paprockiego zob. m.in. Polska-dzieje i rzeczy jej rozpatrywane przez Joachima Lelewela, t. 1, s. 14 nr XLVII; Estreicher, Bibliografia polska, t. 24, s. 
w znaczący sposób także w historiografii naszych południowych sąsiadów. Z tego też okresu pochodzi kolejne z jego dzieł, którego nie sposób pominąć w obecnym przeglądzie. W roku 1602 ukazał się w Pradze drukiem jego Diadochos id est succesio, stanowiący cenne w tamtym czasie opracowanie z zakresu chronologii historycznej ${ }^{82}$. W części poświęconej porządkowi następstwa czeskich monarchów, znajdujemy też rozdział zatytułowany $O$ weyprawie Břetislawa s woyskem do Polsky w roku $1038^{83}$. Pisząc o rabunku relikwii, jakiego dopuścili się wówczas Czesi w gnieźnieńskiej archikatedrze, B. Paprocki stwierdza m.in.: „Wyzdwyhssy těla Swatých Pětji Mučedlnykůw, též tělo swatého Woytěcha, biskupa pražského, a arcybiskupa gnězněnského, spolu s tim wssecken poklad kostelnj wybrali a preč odnesli. Tuto niyakž se hystorykowé aneb kronykáři czessky s polskými srownati nemohau. Nebo polssky pyssy, že ysau tělo Gaudentia, arcybískupa, kterýž tolikéž swateho žiwota byl, tak jakž o tom Cathalogus y kronyky wyswědčuyji, za tělo swatého Woytěcha wzali. Czechowé tolikež podle dawných a starých spraw předkůw swych to za prawdiwau wěc twrdy, že mayi oprawdowe tělo swatého Woytěcha. Toho weswětly mayic diwy weliké, ktere se při tom hrobě swatém dály a deyji" ${ }^{84}$. O najeździe tym cytowany autor wspomina raz jeszcze w części poświęconej z kolei chronologii obsady stolicy biskupiej w Pradze, w życiorysie biskupa Sewera, gdzie też mowa jest o uwiezieniu do stolicy Czech ciała św. Wojciecha, natomiast bł. Radzim-Gaudenty nie jest już w tym kontekście wspominany ${ }^{85}$.

W poczcie pasterzy Kościoła praskiego pióra B. Paprockiego nie mogło oczywiście zabraknąć osoby św. Wojciecha, któremu też poświęcony został osobny rozdział ${ }^{86}$. W tekście tym kilkakrotnie wspomniany został również bł. RadzimGaudenty - po raz pierwszy jako towarzysz starszego brata w podróży z Rzymu do Czech w r. $981^{87}$. Tak samo mowa jest o jego udziale w wyprawach św. Wojciecha na Węgry i do Polski, gdzie - jak czytamy - książę Bolesław Chrobry, po śmierci arcybiskupa gnieźnieńskiego Roberta, ,žadal Woytěcha, aby na myesto yeho wstaupil, čemuž on odporowal, ale přemožen ysa prosbami yiných biskupů mnohych [sic] tak učinil"’8. Długo jednak przyszły patron polskiej prowincji kościelnej rządów pasterskich nie sprawował, lecz „,napomenut ysa we snách skrze anděla Božyho, zanechal na mystě swém Gaudentiusa, a sam se k krayinam

58-79; W. Dworzaczek, Paprocki Barttomiej (Bartosz) herbu Jastrzębiec (ok. 1543-1614), heraldyk, pisarz polityczno-obyczajowy, wierszopis, PSB, t. 25, s. 177-180; Stownik historyków polskich, s. 391; Grabski, Zarys historii historiografii, s. 40-41; Dawni pisarze polscy, t. 3, s. 221-223 (I. Teresińska).

${ }^{82}$ Diadochos id est successio. Sinak poslaupnost knijžat a kràlůw czeských, biskupi̊w y arcibiskupưw pražskych, a wszech třech stanůw slawného Králowstwj Czéskeho, to yest panského, rytiřského a méského krátce sebraná a wydana skrze Bartholomège Paprockého z Glogol a z Paprockéwůle, Praha 1602.

${ }^{83}$ Tamże, s. 82-84.

${ }^{84}$ Tamże, s. 82.

${ }^{85}$ Tamże, s. 284.

${ }^{86}$ Tamże., s. 270-280 (O swatym Woytiechowi).

${ }^{87}$ Tamże, s. 275.

${ }^{88}$ Tamże, s. 278. 
pruským obratil"89. O udziale bł. Radzima-Gaudentego w wyprawie misyjnej św. Wojciecha do Prus mowy oczywiście nie ma, niemniej jego osoba pojawia się raz jeszcze w życiorysie męczennika, a to w związku z dokonaną jakoby przezeń właśnie rzekomą translacją ciała tegoż z Trzemeszna do Gniezna ${ }^{90}$.

Opracowawszy zaprezetnowany tu pokrótce zbiór sylwetek pasterzy Kościoła praskiego, na kilka lat przed śmiercią B. Paprocki wydał drukiem w Krakowie zresztą bezimiennie - także poczet (wierszowany) arcybiskupów gnieźnieńskich, zatytułowany Cathalogus to iest porzadne opisanie spraw y żywota arcybiskupow gnieźnieńskich (pierwsze wydanie, niedatowane, miało miejsce około roku 1608, natomiast drugie w r. 1613) ${ }^{91}$. Niewielkie to dziełko (być może zainspirowane wyżej wspomnianym zbiorem autorstwa Klemensa Janickiego), dedykowane ówczesnemu prymasowi Wojciechowi Baranowskiemu, jawi się niezbyt krytycznym, o czym świadczyć może chociażby przypisanie zasiadającemu na stolicy metropolitalnej w Gnieźnie w latach 1481-1493 Zbigniewowi z Oleśnicy dokonań jego stryja i imiennika, obdarzonego purpurą kardynalską biskupa krakowskiego z lat 1423-1455, jak zakup księstwa siewierskiego, fundowanie kapituły kolegiackiej w Nowym Sączu, czy wzniesienie zamku rodowego w Pińczowie. Rzeczony katalog rozpoczyna się też od „Vilibalmusa, [który] przyiachał roku 966, [a] umarł roku 970"92, natomiast bł. Radzim-Gaudenty zajmuje w nim „uświęcone” przez ową mylną tradycję piąte miejsce - jako bezpośredni sukcesor św. Wojciecha, które to wielce dlań nobilitujące następstwo zostało też wyeksponowane w stosownym wierszu, odnoszącym się do osoby młodszego ze Sławnikowiców:

\footnotetext{
Gaudenyus brat w Chrystu siadł na mieysce iego

Y dochodził sprawami żywotem świętego.

Siedm lat po nim nauczał znać prawdziwie Pana

$\mathrm{W}$ tym się nie pokazała $\mathrm{w}$ tey mierze odmiana.

Pan statecznie naukę z ust wiernego sługi

Prawdowierną zostawi y trwałą czas długi.

Nie długo nam zażywać dał Pan tey pociechy

Pobrał prędko do nieba tak cnotliwe Czechy.

Podzieliwszy krolestwa ich ciały świętemi

Radostowemi Czechy, nas Woyciechowemi ${ }^{93}$.
}

Tu zatem B. Paprocki opowiedział się za tą wersją pośmiertnych losów doczesnych szczątków obu doznających dziś w Kościele braci, wedle której relikwie św. Wojciecha miały pozostać na miejscu w Gnieźnie, co znalazło wyraz również w wierszowanym żywocie rzeczonego męczennika, gdzie czytamy, że, ,jego święte ciało [...] k wieczney ozdobie tu [w] Polszcze zostało"94. Zauważamy zatem, że

${ }^{89}$ Tamże, s. 278.

${ }^{90}$ Tamże, s. 279.

${ }^{91}$ [B. Paprocki], Cathalogus to iest porządne opisanie spraw y żywota arcybiskupow gnieźnieńskich, od zaczęcia wiary świętey katholickiey w Polscze, aż do tego czasu, krotko wierszem opisane, a na światto wydane, Kraków 1613.

${ }^{92}$ Tamże, s. [3].

${ }^{93}$ Tamże, s. [7].

${ }^{94}$ Tamże, s. [6]. 
W adresowanej do polskiego odbiorcy edycji autor ów z sobie wiadomych względów wolał nie dawać wyrazu żywionym w tej materii wątpliwościom, wynikłym z rozbieżności tradycji historiograficznych w Polsce i w Czechach, o czym wszak bez ogródek wspomniał niegdyś w swym Diadochosie.

IV.

Przechodząc w naszej analizie do kolejnego stulecia, tj. XVII (zresztą i dwie spośród wyżej omówionych edycji Bartosza Paprockiego ukazały się już po roku 1600), przegląd drukowanych dzieł ówczesnych historiografów polskich, którzy w swych edycjach (spuściznę rękopiśmienną bowiem z konieczności pomijamy, jako że nie została ona dotychczas $\mathrm{w}$ dostatecznym stopniu zinwentaryzowana i opisana w literaturze przedmiotu $)^{95}$ nie pominęli problematyki pierwocin organizacji diecezjalnej Kościoła na ziemiach polskich, w tym i początków arcybiskupstwa gnieźnieńskiego, rozpocząć należy od polihistora Szymona Starowolskiego (1588-1656), do którego spuścizny po dziś dzień badacze często sięgają. W ostatnim roku życia powołany do grona kapituły katedralnej na Wawelu, w ciągu nie tak znów długiego życia napisał około siedemdziesięciu wartościowych prac, wśród których były m.in. Scriptorum Polonorum Hecatontas (1625), Poloniae sive status Rei Publicae descriptio (1627), czy chyba najwyżej cenione spośród całej jego spuścizny Monumenta Sarmatarum (1655), stanowiące nieocenionej dziś wartości zbiór staropolskich inskrypcji z wielu bardziej i mniej znanych świątyń Rzeczypospolitej ${ }^{96}$. Nas wszakże zainteresuje w omawianym tu kontekście nie należąca do najbardziej eksponowanych w spuściźnie S. Starowolskiego edycja Sarmatiae bellatores, opublikowana w r. 1631 w Kolonii. W zawartym tamże życiorysie Mieszka I czytamy mianowicie, że książe ten „novem numero episcopatus diversis locis erexit"'97, a zatem chodzi o znaną nam już liczbę dwóch arcybiskupstw (Gniezno, Kraków) i siedmiu biskupstw, które powstać miały jakoby jeszcze za czasów pierwszego historycznego władcy Polski. Z kolei w biografii Bolesława I Chrobrego S. Starowolski pisze o rzekomej koronacji tegoż monarchy przy okazji nawiedzenia przez cesarza Ottona III grobu św. Wojciecha w Gnieźnie (,regium diadema ab imperatore impetravit”) ${ }^{98}$, tym niemniej ani w owym kontekście, ani też gdziekolwiek indziej w zbiorze Sarmatiae bellatores nie pojawia się imię arcybiskupa Gaudentego.

${ }^{95}$ Zob. A. Krawczyk, Historiografia krytyczna. Formowanie się nowożytnej postawy naukowej w polskim piśmiennictwie historycznym XVII w., Lublin 1994 (i ten autor ograniczył się w swej analizie tylko do dzieł wydanych drukiem).

${ }^{96}$ Zob. m.in. Polska - dzieje i rzeczy jej rozpatrywane przez Joachima Lelewela, t. 1, s. $18 \mathrm{nr}$ LXX; Krawczyk, Historiografia krytyczna, s. 8; Stownik historyków polskich, s. 493.

${ }^{97}$ Simonis Starovolsci Sarmatiae bellatores [drugi tytuł: Sarmatiae bellatores, seu elogia virorum bellica virtute illustrium, quotquot vel nostra, vel avorum memoria, celebres in Polonia fuere], Coloniae Agrippinae 1631, s. 2 (całość rozdziału: s. 1-3 nr I).

${ }^{98}$ Simonis Starovolsci Sarmatiae bellatores, s. 6 (całość rozdziału: s. 6-9 nr III). 
W latach czterdziestych XVIII w. ukazały się w kraju trzy dzieła autorów pragnących poznać i przybliżyć sobie współczesnym bardziej oraz mniej zamierzchłe dzieje ojczyste, po których mielibyśmy prawo oczekiwać nie pominięcia w owych wywodach osoby bł. Radzima-Gaudentego. Zacznijmy od kontynuującego jeśli nie zapoczątkowane, to w każdym razie ugruntowane przez Bartosza Paprockiego tradycje piśmiennictwa heraldycznego, poczytnego herbarza Orbis Polonus dominikanina Szymona Okolskiego (1580-1653), spod pióra którego to autora wyszły również wznawiane jeszcze w XIX stuleciu prace o dziejach Kościoła katolickiego na Rusi, tj. na obszarze metropolii lwowskiej (pierwotnie halickiej) ${ }^{99}$. Rzeczony herbarz wydany został w latach 1641-1645 w Krakowie w trzech tomach, przy czym nas zainteresuje opublikowany w r. 1643 tom drugi. W rozdziale odnoszącym się do herbu „Rosa alias Poray”, wśród biskupów Polski, którzy mieli być właśnie Różycami, S. Okolski wymienia - obok św. Wojciecha, dalej Wernera płockiego i Bodzanty krakowskiego - także Gaudentego ${ }^{100}$. Nie chodzi mu wszakże o tego właśnie hierarchę, któremu poświęcone jest obecne studium, określa go bowiem mianem „Cracoviensis episcopus” i odsyła zarazem do wydanego w r. 1593 dziełka Krzysztofa Kantckiego vel Kąckiego Vitae archiepiscoporum et episcoporum Ecclesiae Cracoviensis, w którym odnośny życiorys dotyczy pasterza Kościoła krakowskiego z lat 1118-1142 Radosta („Gaudentius seu Radost”) ${ }^{101}$. S. Okolski w ogóle zatem nie zna osoby przyrodniego brata św. Wojciecha, o którym to ostatnim pisze oczywiście jako o arcybiskupie Gniezna ${ }^{102}$.

W tymże samym roku 1643, tyle że w odległej Antwerpii, wydane zostały pośmiertnie dzieła zmarłego trzy lata wcześniej pasterza diecezji płockiej (uprzednio zaś łuckiej i zarazem podkanclerzego koronnego) Stanisława Łubieńskiego. Pochodził on z rodu wielce zasłużonego w dziejach XVII- i XVIII-wiecznej Rzeczypospolitej Obojga Narodów, a także w pierwszym stuleciu po rozbiorach, który wydał aż siedmiu biskupów, w tym dwóch prymasów (jednym z nich był starszy brat Stanisława - Maciej Łubieński, arcybiskup Gniezna w latach 16411652). Pełen zamiłowania do pracy naukowej, S. Łubieński zasłużył się w szczególności właśnie na polu piśmiennictwa historycznego - zarówno jako świadek opisujący własną epoką, jak i erudyta spoglądający ku odleglejszej przeszłości ${ }^{103}$.

${ }^{99}$ M.in. W. Dworzaczek, R. Świętochowski, Okolski Szymon herbu Rawicz (1580-1653), dominikanin, prowincjat, teolog, historyk i heraldyk, PSB, t. 23, s. 679-681; SPTK, t. 3, s. 241-243 (E. Ozorowski); Stownik historyków polskich, s. 380; Grabski, Zarys historii historiografii, s. 52.

${ }^{100}$ S. Okolski, Orbis Polonus, t. 2, Cracoviae [1643], s. 635.

${ }^{101}$ Vitae archiepiscoporum et episcoporum Ecclesiae Cracoviensis, Christophori Kantski, artium liberalium magistri [...], Cracoviae 1593, s. 15 nr XIII. Wspomniani w tytule arcybiskupi krakowscy, to Prohor, Prokulf, Lambert, Poppo, Gompo, Rachelin i Aaron, a więc postaci odnoszone do X i XI stulecia - poprzednicy owego Lamberta-Suły, który „,neglexit archiepiscopatum” (zob. wyżej przyp. 36).

${ }_{102}$ Okolski, Orbis Polonus, t. 2, s. 634.

${ }^{103}$ M.in. Polska - dzieje i rzeczy jej rozpatrywane przez Joachima Lelewela, t. 1, s. $16 \mathrm{nr}$ LXa; W. Czapliński, Łubieński Stanisław herbu Pomian (1573-1640), biskup tucki, potem plocki, podkanclerzy, historyk, PSB, t. 18, s. 498-501; HNP, t. 6, s. 381; SPTK, t. 2, s. 580-582 (E. Ozorowski); Krawczyk, Historiografia krytyczna, s. 7; Stownik historyków polskich, s. 320; K. R. Prokop, Sylwetki biskupów luckich, Biały Dunajec-Ostróg 2001, s. 80-88; Dawni pisarze polscy, 
W ten drugi nurt wpisywał się jego pióra zbiór życiorysów zasiadających przed nim na stolicy biskupiej w Płocku hierarchów, poniekąd nawiązujący do wspomnianego wyżej katalogu Długosza. Zatytułowany Vitae et series episcoporum Plocensium (w literaturze podawany jest również alternatywny tytuł Series, vitae, res gestae episcoporum Plocensium), ukazał się on drukiem właśnie w ramach owej pośmiertnej edycji Opera posthuma, przynosząc wcale pokaźny zbiór wiadomości do interesującej nas obecnie problematyki ${ }^{104}$.

I tak w skreślonym przez Stanisława Łubieńskiego życiorysie umieszczonego przezeń na drugim miejscu w szeregu biskupów Płocka Marcjalisa, którego pasterzowanie miało przypaść jakoby na schyłek X w. (nie trzeba przypominać, że diecezja płocka powołana została do istnienia dopiero za czasów Bolesława II Szczodrego vel Śmiałego), czytamy też o przybyciu do Polski św. Wojciecha, który ,a Boleslao Chobrio, monarcha adhuc et non rege, benigne exceptus et ab universo populo omni genere piae hospitalitatis cultus est. Hunc idem princeps [...], archiepiscopatum Gnesnensem mortuo Roberto vacuum, suscipere magnis precibus coegit; quem cum ille triennio administrasset, martyrii consequendi ardens studio, subrogato in suum locum, et in archiepiscopatu relicto fratre suo germano Radzino dicto (sive tu Gaudentium Vandalico nomine in latinum verso, dicere malueris) in Prussiam assumptis aliquot viris religiosis se contulit" ${ }^{105}$. Są to zatem owe powtórzone w ślad za starszym piśmiennictwem nieprawdziwe informacje o okolicznościach i czasie osadzenia na arcybiskupstwie gnieźnieńskim Radzima-Gaudentego, nad którymi można by zgoła przejść do „porządku dziennego", zważywszy na gruntownie już utrwaloną tradycję historiograficzną, na której poparcie każdy kolejny autor mógł przywołać coraz to liczniejsze grono uznanych autorytetów, gdyby nie pewna nadzwyczaj istotna okoliczność. Otóż w dalszej części swych wywodów S. Łubieński wskazuje, że znane było mu również świadectwo kroniki Thietmara, do której też odwołuje się pisząc o zjeździe gnieźnieńskim w roku 1000, nie omieszkawszy odnieść się do zawartej tamże relacji o owym wydarzeniu. Mielibyśmy zatem do czynienia z niewątpliwym postępem, czy zgoła przełomem (ku któremu pewną podstawę dawało już zresztą starsze o cztery dziesięciolecia tłumaczenie dzieła C. Baroniusza Annales ecclesiastici) w staropolskim piśmiennictwie historiograficznym w postrzeganiu kwestii momentu powołania do istnienia metropolii gnieźnieńskiej wraz z jej sufraganiami, gdyby tylko S. Łubieński potrafił z należytym krytycyzmem ocenić wiarygodność dostępnych mu świadectw, tudzież miał odwagę odrzucić ów fałszywy obraz początków organizacji diecezjalnej w Polsce, pomimo opowiedzenia się za nim wielu jego zasłużonych poprzedników w trudzie opisywania ojczystych dziejów. Tak się jednak nie stało, jako że uznanie wiarogodności świa-

\footnotetext{
t. 2, s. 393 (I. Teresińska); W. Graczyk, Stanisław Łubieński - pasterz, polityk, pisarz - 1574-1640, Kraków 2005.

104 Ostatnio na temat katalogu biskupów płockich pióra S. Łubieńskiego pisał Graczyk, Stanisław Łubieński, s. 333-341. Zob. także Krawczyk, Historiografia krytyczna, s. 369-372.

${ }^{105}$ S. Łubieński, Vitae et series episcoporum Plocensium, [w:] Stanislai Lubienski, episcopi Plocensis, opera posthuma, historica, historico-politica, variique discursus, epistolae et aliquot orationes [...], Antverpiae 1643, s. 311.
} 
dectwa Thietmara w owym względzie pociągało by za sobą konieczność przesunięcia o wiele dziesięcioleci później dat powstania szeregu diecezji, w tym również płockiej, a w konsekwencji pozbawiło by je splendoru „starożytności”, skoro dotychczas twierdzono, że powstały one - jak i cała metropolia gnieźnieńska - od razu w momencie chrztu Polski. S. Łubieński do świadectwa merseburskiego biskupa podszedł zatem z apriorycznym założeniem, że jest ono nieprawdziwe, i w tym też kierunku poszły jego dalsze wywody.

Dla falsyfikacji całego przekazu Thietmara o przebiegu zjazdu gnieźnieńskiego w roku 1000 posłużył mu właśnie argument rzekomo niezgodnego z rzeczywistością ukazania kwestii początków organizacji diecezjalnej na ziemiach polskich. Autor życiorysów biskupów płockich stwierdza mianowicie: „Dithamarus tot falsis narrationibus farsit suam Historiam, ut ei, uti Poloni osori, fides haberi non possit. Ac ut caetera taceamus, quis unquam credet, Boleslao demum principe, archiepiscopum Gnesnensem esse constitutum, cum parietes ipsi loquantur, ab Aegidio, episcopo Tusculano, cardinali, auctoritate Joannis XIII, Summi Pontificis, prope quadraginta antequam Otto imperator in Poloniam venisset annis, ita statutum ecclesiasticum formatum fuisse, ut et Gnesnae ac Cracoviae essent archiepiscopi, et reliquas cathedras tenerent episcopi ac sanctus ille Adalbertus ab omnibus scriptoribus Gnesnensis Ecclesiae archiepiscopali dignitate fuisse ornatus perhibeatur" ${ }^{106}$. Prowadząc dalej ów na swój sposób z pewnością interesujący «rozbiór krytyczny» kronikarskiego świadectwa Thietmara o zjeździe gnieźnieńskim, S. Łubieński pisze: „Dithamarus quam turpiter errat, dum imperatoris ad Gnesnam accessum refert, audiamus. «Videns - inquit - a longe Gnesnam urbem desideratam, nudis pedibus suppliciter advenit et ab episcopo eiusdem Vngero venerabiliter susceptus, in ecclesiam introducitur [...]». Sistamus hic paulisper stylum et ex Dithamaro quaeramus, cuiusnam urbis episcopus fuit Ungerus? Respondebit ille paulo inferius, hunc Posnaniensem episcopum fuisse; cur igitur Gnesnae illum adscribit, cum tum Radinium, divi Adalberti germanum fratrem, archiepiscopum Gnesna habuerit?"107. Z kolei sięga Łubieński po ów szczególnie istotny fragment odnoszącego się do wydarzeń roku 1000 opisu merseburskiego biskupa, gdzie czytamy (nadal idąc za wywodami XVII-wiecznego autora), że po przybyciu do Gniezna cesarz Otto „«fecit ibi archiepiscopatum, [...] committens eundem praedicti martyris fratri Kadimo (Radinum rectius dixisset) eique subiiciens Reinbernum, Sanctae Cholbergiensis Ecclesiae episcopum, Popponem Cracuensem [sic], Ioannem Vuioteslanensem [sic], Vngero Posnaniensi excepto [...]». Somniare videtur nescio quas tricas iste bonus scriptor et de re sibi ignota texit fabulam, dum et archiepiscopum et aliquot episcopos, corruptis et in Polonia vix auditis nominibus, ab Ottone nobis datos temere fingit, quos et plures alios, Summi Pontificis Joannis XIII auctoritate constitutos iam dudum habuimus. Errantem corrigere voluit cardinalis Baronius, asserens hos archiepiscopatum et episcopatus, auctoritate archidiaconi Sacrae Romanae Ecclesiae cardinalis, qui cum Ottone huic actui praesens adfuit, ordinatos fuisse; sed bona venia tanti viri

\footnotetext{
106 Tamże, s. 312.

107 Tamże, s. 313.
} 
dictum sit, meminisse enim debuerat quid sub annum nongentesimum sexagesimum sextum scripserit, de misso in Poloniam a Joanne XIII Aegidio, episcopo Tusculano, cardinali, formatoque in Polonia ecclesiastico statu, nosque ab eo ipso Aegidio in Polonia episcopos ordinatos fuisse, supra ostendimus" (itd.) ${ }^{108}$. Po dalszych jeszcze wywodach w tym samym duchu, których przytaczanie tu nie wydaje się nieodzowne, S. Łubieński stwierdza w konkluzji: „Duo, ut supra diximus, erant $a b$ initio susceptae religionis in Polonia fundati archiepiscopi, Gnesnensis et Cracoviensis; ille quidem nunquam intermissa ea dignitate ad nostra usque tempora, per tot successores, quos prope septingenti anni continuo suppeditarunt, retinet sedem et praeeminentiam metropoliticam. Hic vero cum eadem etiam ab initio dignitate fulgeret, septem archiepiscopos sibi invicem succedentes habuit, quorum ultimus fuit Aaron [...]. Eius successor Lampertus Zula primus non petito a Summo Pontifice novo palio, dignitate episcopali contentus fuit"109.

Biskup Stanisław Łubieński nie posunął zatem ani o krok naprzód stanu wiedzy w przedmiocie pierwocin organizacji diecezjalnej na ziemiach Polski wczesnopiastowskiej oraz o okolicznościach utworzenia arcybiskupstwa w Gnieźnie i osadzenia na nim bł. Radzima-Gaudentego. O tym ostatnim wspomina zresztą raz jeszcze, tym razem w związku z rzekomą koronacją Bolesława Chrobrego, pisząc: „Habuit itaque Polonia semper archiepiscopum, neque ostendi potest illum alio tempore, nisi sub initium susceptae religionis, constitutum et ordinatum fuisse. Immo vero manifeste apparet, ab archiepiscopo Gnesnensi Radimo sive Radzino, divi Adalberti fratre, viro sancto, pio et religioso, atque in Urbe Romana una cum sancto Adalberto educato, praesente Ottone imperatore et archidiacono Sacrae Romanae Ecclesiae cardinali, Summi Pontificis Sylvestri II. auctoritate accedente, Boleslaum, primum Poloniae regem, didemate regio exornatum fuisse"110. W sytuacji, gdyby S. Łubieńskiemu nie było znane świadectwo kroniki Thietmara, łatwiej by było go usprawiedliwić na okoliczność „trwania w błędzie” i opowiedzenia się za tą właśnie nieprawdziwą, niemniej schlebiającą dumie narodowej wizją pierwocin gnieźnieńskiej metropolii, w ramach której funkcjonowało później także biskupstwo płockie. Owa jednak „nieznośna lekkość”, z jaką odrzucił przekaz współczesnego kronikarza (przynależącego zresztą - tak, jak on sam - do grona episkopatu), zarzucając mu świadome mijanie się z prawdą, a nie mniej zgoła prześmiewczy styl, obfitujący w sformułowania zdradzające pewne lekceważenie w stosunku do osoby autora kronika i przede wszystkim jego świadectwa, wystawiają temuż pisarzowi mało chlubne świadectwo.

Także obszerne, choć nie aż tak obfite wywody w interesującej nas tematyce, znajdujemy w trzecim spośród wydanych w latach czterdziestych XVII w. dzieł, którego w obecnym przeglądzie nie sposób pominąć. Mowa o opublikowanym w Warszawie w roku 1649 zbiorze Series archiepiscoporum Gnesnensium kanonika regularnego laterańskiego z konwentu w Kaliszu Stefana Damalewicza $(\dagger$ 1673), nota bene niegdysiejszego kapelana domowego wspomnianego wcześniej Macieja Łubieńskiego (jeszcze jako ordynariusza włocławskiego), który to au-

\footnotetext{
${ }^{108}$ Tamże, s. 313-314.

${ }^{109}$ Tamże, s. 314.

${ }^{110}$ Tamże, s. 315.
} 
tor miał już w swoim dorobku analogiczne Vitae episcoporum Vladislaviensium $(1642)^{111}$. W odróżnieniu od S. Łubieńskiego Damalewicz z Thietmarem polemiki już nie podejmuje i nawet na niego się nie powołuje, lecz w „pokorze” względem darzonych autorytetem poprzedników na niwie piśmiennictwa historiograficznego umieszcza bł. Radzima-Gaudentego w poczcie arcybiskupów Gniezna na piątym miejscu - po Wilibaldzie, Hattonie, Robercie i św. Wojciechu, również w pozostałych kwestiach, odnoszących się do curriculum vitae tego hierarchy, podążając drogą wytyczoną przez Długosza, Miechowitę i kontynuatorów. Tak więc o interesującej nas postaci czytamy po raz pierwszy w życiorysie św. Wojciecha (jako rzekomego metropolity gnieźnieńskiego), gdzie stwierdzone zostało: „Mortuus interim anno Domini 996 Robertus, archiepiscopus Gnesnensis, viduam reliquit metropolim, cuius gubernacula ut susciperet Adalbertus, magnis institit precibus Boleslaus princeps; ubi cum per tempus aliquantum praedicando laborasset [...], viso nocturno divinitus admonitus, ad Prussorum conversionem se vertit, et susceptam peregrinationem, frustra eum retinere nitentibus Polonis, prosequitur, Gaudentio sive Radzino in locum suum suffecto" "12. Podobnie rzecz ujęta została w życiorysie samego Radzima-Gaudentego, czytamy tam bowiem, iż „cum gemitu supremum dixit antistiti vale, iter in Prussiam adornati [mowa o św. Wojciechu], Gaudentium vero, fratrem eius germanum, ad metropolitanam sedem evexit, Miecislao principe id per literas et nuncios apud Gregorium V. [...] postulante, anno eodem, quo a Prussis divus Adalbertus est interemptus. Nam Gregorius V. creatus Pontifex anno 995, obiit anno 998; itaque qui 999 anno a Gaudentio dicunt regimen metropolitanae Ecclesiae inchoatum, non possunt ipsius confirmationem ad Gregorium V. referre"113. Dostrzegamy zatem, że Damalewicz zdawał sobie sprawę z rozbieżności zachodzących pomiędzy świadectwem zabytków rocznikarskich, a obrazem wyłaniającym się z piśmiennictwa historiograficznego, jednakże problem potraktował w sposób mało pogłębiony, poprzestając poniekąd na samym stwierdzeniu faktu. Po tym raczy on czytelnika schematyczną opowieścią o gorliwości i zaangażowaniu Radzima-Gaudentego w trudy pracy pasterskiej, w czym miał być godnym kontynuatorem starszego brata (kolejna reminiscencja Gallowego „frater et successor”), wspominając też pobieżnie o przeszkodach, jakich doświadczał, czego pochodną stanowiła rzucona przezeń na miasto Gniezno „ob teterrima scelera” klątwa, tego zaś konsekwencją miał okazać się późniejszy najazd Czechów pod wodzą Brzetysława I ${ }^{114}$.

W dalszej kolejności S. Damalewicz wspomina o zjeździe gnieźnieńskim, przy czym w owym opisie znajdujemy te same, co u J. Herburta, słowa odnośnie

${ }^{111}$ M.in. M. Morawski, Damalewicz Stefan, ksiądz, PSB, t. 4, s. 397; HNP, t. 6, s. 116; SPTK, t. 1, red. H. E. Wyczawski, Warszawa 1981, s. 360-362 (E. Ozorowski); Krawczyk, Historiografia krytyczna, s. 6-7; Słownik historyków polskich, s. 98-99.

112 Series archiepiscoporum Gnesnensium atque res gestae e vetustis antiquitatum ruderibus collectae [...] per Stephanum Damalevicium Vartam, Sacrae Theologiae doctorem, Canonicorum Regularium Congregationis Laternanensis ad Sanctum Nicolaum Calissii praepositum [...], Varsaviae 1649, s. 64 (całość życiorysu na s. 58-65).

${ }^{113}$ Tamże, s. 65 (całość życiorysu na s. 65-69).

114 Tamże, s. 65. 
do uwieńczenia Bolesława Chrobrego monarszym diademem „Gaudentio archiepiscopo solennes caeremonias peragente" ${ }^{115}$. Damalewicz dodaje też od siebie, że od tego właśnie momentu datuje się usankcjonowana przez Stolicę Świętą tradycja koronowania polskich monarchów przez arcybiskupów Gniezna (,quam authoritatem ungendi et coronandi reges Poloniae a Sede Apostolica adeptus Gaudentius ad successores archiepiscopos transmisit") ${ }^{116}$. Co się tyczy z kolei zgonu interesującego nas hierarchy, autor Vitae archiepiscoporum Gnesnensium datuje ów fakt na rok 1006, stwierdzając przy tej okazji, że na stolicy gnieźnieńskiej Radzim-Gaudenty zasiadał przez lat dziewięć (tj. od roku 997, czyli od śmierci św. Wojciecha), a tym samym wątpliwość odnośnie do daty początkowej jego pontyfikatu rozstrzygnął na niekorzyść znajdującego oparcie we współczesnych źródłach roku $999^{117}$. Wreszcie na samym końcu omawianego życiorysu - zresztą analogicznie, jak przy wszystkich postaciach - S. Damalewicz umieścił wierszowany epigramat o następującym brzmieniu:

Frater, Adalberti post fatum sume tiaram,

Gratus erit simili Praesul odore Rosae.

Martyrio rubet illa; Tuam fovet aemula virtus.

Illa viget fuso sanguine, pace Tua

Ergo tuam candor, fraternam purpura vestit,

Sic pulchre Lechico crescitis orbe Rosae ${ }^{118}$

Jak lata czterdzieste XVII w. przyniosły druk aż trzech zaprezentowanych tu dzieł historiograficznych, których nie sposób było pominąć przy omawianiu obecności bł. Radzima-Gaudentego w staropolskim piśmiennictwie, dotyczącym dziejów państwa i Kościoła, tak samo lata sześćdziesiąte tegoż stulecia zaowocowały równie pokaźną liczbą publikacji wymagających uwzględnienia w niniejszym przeglądzie. Jeszcze mianowicie w roku 1662 ukazała się w Krakowie Forteca duchowna Królestwa Polskiego z żywotów świętych autorstwa związanego z Akademią Krakowską Piotra Hiacynta Pruszcza (1605-po 1667), bardziej znanego historykom z przypisywanych mu Stołecznego miasta Krakowa kościotów i klejnotów (1647) ${ }^{119}$. W rzeczonym zbiorze nie mogło zabraknać Żywotu $b$ [łogosławionego] Gaudencyusa, arcybiskupa gnieźnieńskiego, o którym P.H. Pruszcz pisze, że był to „brat rodzony świętego Wojciecha”"120. W zgodzie też z utartą tradycją informuje czytelnika, że „temu [to] Gaudencyusowi, abo po polsku Radzynowi, święty Wojciech arcybiskupstwo gnieźnieńskie zostawiwszy y

115 Tamże, s. 67-68 (opis zaczynający się od słów: „Volentes autem tam splendido hospiti et amico principi parem referre gratiam”, itd. - zob. wyżej przyp. 54).

116 Tamże, s. 68.

117 Tamże, s. 68.

${ }^{118}$ Tamże, s. 69.

119 M. Rożek, Pruszcz Piotr Jacek (Hiacynt) (1605-po 1667?), autor opisu Krakowa i pism dewocyjnych, PSB, t. 28, s. 599-600; SPTK, t. 3, s. 445-446 (E. Ozorowski); Stownik historyków polskich, s. 427; Encyklopedia Krakowa, Warszawa-Kraków 2000, s. 815.

${ }^{120}$ P. H. Pruszcz, Forteca duchowna Królestwa Polskiego z żywotów świętych, tak już kanonizowanych $i$ beatyfikowanych, jako tez świątobliwie zyjących patronów polskich [...], Kraków 1662, s. 30 . 
na to poświęciwszy, dwu kapłanów, Krystyna i Papata, przy nim zostawił, a sam do Prus dla nawrócenia pogaństwa do wiary świętej katolickiej poszedł"121. Mamy zatem pewne nowe elementy biografii Radzima-Gaudentego w postaci zarówno imion dwóch przydanych mu rzekomo przez św. Wojciecha współpracowników (o Chrystianie vel Krystianie i Papacie czytamy zresztą już w Żywotach świętych P. Skargi) ${ }^{122}$, jak przede wszystkim informacji, że to sam późniejszy męczennik i patron metropolii udzielił swemu bratu i „następcy” sakry biskupiej (jest to ewidentna nadinterpretacja świadectwa zawartego u Długosza). Nie jedyna to zresztą nowość, z jaką spotykamy się w curriculum vitae tegoż hierarchy w Fortecy duchownej, bowiem po informacji, że bł. Radzim-Gaudenty „skończył bieg żywota swego roku 1006, dnia 8 listopada, [i] pochowany [został] w kościele katedralnym gnieźnieńskim, gdzie cudami słynie" ${ }^{23}$ (Pruszcz zna zatem rzekomą datę dzienną śmierci owegoż hierarchy, różną od tej zawartej w nekrologach czeskim $(12 \mathrm{X})$ i lüneburskim $(14 \mathrm{X})^{124}$, nie wie natomiast o najeździe z r. 1038 i uwiezieniu jego ciała do Czech), jako ilustrację tych cudów przytacza historię niejakiego „Tomasza, studenta z Pragi, [który] dla występku swego niewielkiego dany był do ciemnego więzienia, w którym ustawnie błogosławionego Gaudencyusa wzywał, aby swoią świętą przyczyną u Pana Boga z onego więzienia wybawił", co też rzeczywiście nastąpiło. I dalej czytamy, że po owym cudownym wyswobodzeniu „Tomasz dobrodziejstwa tego pamiętny będąc, na cześć i na chwałę Panu Bogu y temu Błogosławionemu (będąc arcybiskupem gnieźnieńskim [sic]) ksiąg kościołowi nakupił i psałterzystów fundował" 125 .

Dla uwiarygodnienia swych wywodów P.H. Pruszcz nie omieszkał przy każdym z żywotów zamieszczonych przezeń w owym zbiorze zawrzeć „bibliografii”, w przypadku bł. Radzima-Gaudentego wskazują na herbarz Bartosza Paprockiego i Officia propria patronum provinciae Poloniae Stanisława Sokołowskiego (15371593), kaznodziei króla Stefana Batorego, a z zagranicznych autorów przywołując także Johanna von Tritheima vel Trittenheima (1462-1516), zwanego częściej Tritemiusem (Thrithemius), będącego wykształconym w Trewirze i Heidelberdze benedyktynem, od r. 1506 opatem klasztoru św. Jakuba w Würzburgu, który pozostawił po sobie m.in. Liber scriptorum ecclesiasticorum i Catalogus illustrium virorum Germaniae, oraz czeskiego kronikarza Václava Hájka z Libočan († 1553), katolickiego kapłana i dziekana w Karlštejnie. Ów był autorem cieszącej się przez długi czas znaczną poczytnością kroniki obejmującej dzieje Czechów od najdawniejszych czasów (Kronika česká, powstała w latach 1534-1539 i wydana po raz pierwszy w r. 1541), w której oczywiście wiele miejsca poświęcone zostało św. Wojciechowi, a nie pominięto przy tym także osoby jego przyrodniego brata Gaudentego. Mianowicie już pod rokiem 995 czytamy u Hájka, że wówczas to

${ }^{121}$ Tamże, s. 31.

${ }_{122}$ Żywoty świętych Starego y Nowego Zakonu, s. 354.

${ }^{123}$ Tamże, s. 31.

${ }^{124}$ Zob. np. Semkowicz, Krytyczny rozbiór «Dziejów polskich», s. 97; G. Labuda, Gaudenty, czesk. Radim, polsk. Radzim, pierwszy arcybiskup polski w Gnieźnie, PSB, t. 7, s. 308-309; Labuda, Radzim, czes. Radim, łac. Gaudenty, pierwszy arcybiskup polski w Gnieźnie, s. 457.

${ }^{125}$ Pruszcz, Forteca duchowna Królestwa Polskiego, s. 31. 
„Vojtěch pak a Gaudencius do polské zemi přišedše, kázali slovo Boží a když přišli do Gnízdna, tu Vojtěch [pro] Gaudencia v tom městě místo biskupa učinil a práci duchovní jemu poručiv, sám odšel a po městečkách, po vsech chodě víru Kristovu oznamoval a mnoho Polákuov pokrtill" ${ }^{26}$. Z kolei pod rokiem 999 pojawia się w tymże dziele oparta na przekazach rocznikarskich informacja, trudna do pogodzenia z poprzednią, iż ,téhož léta Gaudencius, jenž byl bratr duchovní a v náboženství tovaryš Vojtěcha, někdy biskupa českeho, ten jest na biskupství gnězdnenské vyzdvižen a tu biskupem (tak jakž se sv. Vojtichu líbilo) učiněn" 127.

Mimo owej niespójności dostrzegamy wszakże inne nieco, aniżeli w polskim piśmiennictwie historycznym tego czasu rozłożenie akcentów, po pierwsze bowiem nie ma tu mowy, aby św. Wojciech sprawował rządy w Kościele gnieźnieńskim przed bł. Radzimem-Gaudentym (czy w ogóle kiedykolwiek) i ustąpił na jego rzecz z tej funkcji, podobnie jak też brak najwyraźniej miejsca i na cały ów rozbudowany poczet hierarchów, od Wilibalda poczynając, skoro dopiero to sam późniejszy męczennik ,učinil místo biskupa” w Gnieźnie - właśnie dla Gaudentego. Dalej w obu przytoczonych fragmentach kroniki mowa jest tylko o biskupstwie, nie zaś o arcybiskupstwie gnieźnieńskim, wreszcie też czytamy, że osadziwszy na tejże stolicy swego „duchownego brata” (,bratr duchovni”[!]), św. Wojciech bynajmniej nie wyruszył od razu na misję do Prusów, lecz poświęcił się chrystianizowaniu Polski. Tego wszakże ,zestawu” informacji P.H. Pruszcz i kolejni autorzy polscy, o których dalej, od V. Hájka nie przejęli, woląc poprzestać na tym, co znali z rodzimych zabytków późnośredniowiecznego i nowożytnego piśmiennictwa historiograficznego. W jakiejś mierze widać to również, gdy wczytać się w zawarte w dziele kronikarskim dziekana z Karlštejnu opisy zjazdu gnieźnieńskiego ${ }^{128}$ oraz nieszczęsnego najazdu księcia czeskiego Brzetysława I na Polskę, podczas którego uwieziono z Gniezna do Pragi doczesne szczątki obu Sławnikowiców ${ }^{129}$. Jedynie ostatni z fragmentów kroniki V. Hájka, gdzie mowa jest o Radzimie-Gaudentym, został przez P.H. Pruszcza bez szczególnych obiekcji wykorzystany dla wzbogacenia zawartego w Fortecy duchownej życiorysu zażywającego czci hierarchy. Tyle, że polski autor posłużył się swoistą licentia poetica i w sposób dowolny przekomponował tudzież wzbogacił opowieść

126 Václava Hájka z Libočan Kronika česká, t. 2 - Zánik pohanství. R. 905-1110, vyd. V. Flajšhaus (Staročeska Knihovna, t. 3), Praha 1923, s. 161-162 (z późniejszej daty nagłówkiem: Vojtěch a Gaudencius).

${ }^{127}$ Tamże, t. 2, s. 172.

128 Tamże, t. 2, s. 177-178 (Otto III. v Hnězdně - pod rokiem 1001), gdzie czytamy także, iż „stalo se jest nazajtří, že v kostele hlavním tu v Gnízdni, při př́itomnosti sv. Gaudencia, gneznenského kostela biskupa, a jiných pánuov a rytíruov polských, kníže Boleslav Chrabrý jest slavni korunau královskau korunován".

129 Tamże, t. 2, s. 270-276 (Čechové v Hnězdně - pod rokiem 1039) i 276-281 (Přenesení sv. Vojtěcha), gdzie nie zabrakło również informacji, iż „vzali jsú také i tělo sv. Gaudencia, kterýž byl někdy biskupem téhož kostela gnízdnenského" (Tamże, t. 2, s. 276). Opis ten w całości oparty jest na kronice Kosmasa, jakkolwiek ów ostatni bynajmniej nie odmawia Radzimowi-Gaudentemu tytułu arcybiskupiego (,archipraesul eiusdem civitatis nomine Gaudentius”, ,archiepiscopus Gaudentius”, itd.), podczas gdy V. Hájek konsekwentnie określa go tylko i wyłącznie mianem biskupa. 
o cudownym uwolnieniu z więzienia za sprawą niegdysiejszego pierwszego arcybiskupa Gniezna, jako że o ten właśnie wątek chodzi w tym momencie.

Dla zilustrowania zjawiska osobliwego nawarstwiania się określonej fikcji historiograficznej - kolejnej już zresztą, z jaką mamy do czynienia w odniesieniu do bł. Radzima-Gaudentego - nieodzowne wydaje się szczegółowsze nieco przeanalizowanie stosownego fragmentu kroniki V. Hájka (choć nie należy ona do polskiego piśmiennictwa), by móc odnieść do niej zawarty powyżej fragment narracji Piotra Hiacynta Pruszcza, jak i - w dalszej kolejności - analogiczne opowieści Stanisława Sczygielskiego, Kaspra Niesieckiego i Floriana Jaroszewicza, o których mowa będzie niżej. Owa relacja o wydostaniu więźnia na przekór prawom natury z miejsca jego odosobnienia nie jest bynajmniej wymysłem XVIwiecznego dziejopisa czeskiego, lecz zaczerpnięta została przezeń - jak i mnóstwo innych wiadomości na temat dziejów Czech za pierwszych Przemyślidów - z kroniki Kosmasa (1045-1125), dziekana kapituły praskiej. W księdze II swego dzieła, bez odniesienia do konkretnej daty rocznej (pomimo widniejących na początku słów „eodem anno"), pomiędzy kolejnymi fragmentami traktującymi o faktach z lat siedemdzięsiątych i osiemdziesiątych XI w., kronikarz ten opisał wydarzenie, którego sam był uczestnikiem, gdy kształcił się w szkole katedralnej w Pradze. Kiedy mianowicie odmawiał psalmy w katedrze św. Wita, w krypcie śś. Kosmy i Damiana, stanął przed nim człowiek z darami, chcąc je ofiarować do grobu bł. Radzima-Gaudentego w podzięce za swe cudowne uwolnienia. Opowiedział też wówczas młodemu Kosmasowi własną historię, z której wynikało, że przez trzy lata przebywał ,in urbe Krakov in subterraneo carcere, in quo una fenestrula desuper erat, qua mihi panem raro et aquam porrigebat", i że ten jego nieszczęsny los odmieniony został za sprawą interwencji z niebios. Pewnego dnia stanął przed nim mąż o jaśniejącym obliczu i w śnieżnobiałej szacie, dzięki któremu wkrótce w cudowny sposób znalazł się na wolności, a wówczas też ówże przybyły z zaświatów wybawiciel polecił mu udać się do Pragi i w krypcie śś. Kosmy i Damiana złożyć dar u swego grobu, oznajmiając wówczas, że jest bratem św. Wojciecha, imieniem Radzim (,ego sum Radim, sancti Adalberti frater”). Po tych słowach miał zniknąć sprzed oczu zaskoczonemu biegiem wydarzeń człowiekowi, który wszakże uczynił następnie, co mu zostało polecone ${ }^{130}$.

Należy w tym miejscu wyraźnie zaznaczyć, że kronikarz Kosmas ani nie podaje imienia owego pragnącego złożyć dar na grobie bł. Radzima-Gaudentego człowieka, ani też nie wspomina nic o jego dalszych losach. Nie inaczej też czyni Václav Hájek, który niemal że dosłownie przytacza świadectwo XI-wiecznego autora, umieszczając je też pod konkretną datą, mianowicie pod rokiem 1070 oraz dodając od siebie w zakończeniu: „Mladenec [mowa o Kosmasie - KRP] to vys-

${ }^{130}$ Np. Die Chronik der Böhmen des Cosmas von Prag, hrsg. von B. Bretholz (Monumenta Germaniae Historica. Scriptores rerum Germanicarum. Nova series, t. 2), Berlin 1923, s. 130-131 nr XXXIV (oryginał łaciński); Kosmova kronika česká, vyd. J. Svába (Odkaz minulosti české, t. 10), Praha 1950, s. $118 \mathrm{nr} 34$ (tłumaczenie czeskie); Kosmasa Kronika Czechów, wyd. M. Wojciechowska, Warszawa 1968, s. 270-271 (thumaczenie polskie). Por. G. Labuda, Święty Stanisław - biskup krakowski, patron Polski. Śladami zabójstwa, męczeństwa, kanonizacji, Poznań 2000, s. 60 (gdzie wszakże informacja, jakoby miejscem uwięzienia była Praga). 
lyšav, hrob sv. Radima i oltàr̆ ss. Kozmy a Damiana jemu [tj. owemu składającemu dar - KRP] ukázal a to, co se stalo, v své knihy napsal. Jakož pak při těch hrobích tu v kostele častokrát divní divové se toho času ukazovali, zvláště strážným, kteříž časem nočním světlo osvěcovali v lampách a jiné svíce k tomu zřízené"131. Skąd zatem tak dalece różna wersja owej opowieści u P.H. Pruszcza, a potem także S. Sczygielskiego, K. Niesieckiego i F. Jaroszewicza? Na jakiej podstawie autor Fortecy duchownej przypisał tej postaci imię Tomasz, jak i uznał, że był to „student z Pragi, [który] dla występku swego niewielkiego dany był do ciemnego więzienia", tego nie wiemy. Nie wykluczone jednak, że jest to jego własny wymysł, skądinąd bowiem nie ulega wątpliwości, że ze znalezioną w dziele Hájka historią o cudownej interwencji bł. Radzima-Gaudentego obszedł się on w sposób bardzo swobodny. Wszak Kosmas, a w ślad za nim Hájek wyraźnie piszą, że ów cudownie uwolniony dopiero post factum dowiedział się, komu zawdzięcza swe wyswobodzenie, podobnie jak nie ma tam wzmianki, że o takowe poprzednio się modlił. U Pruszcza natomiast ów Tomasz za pobytu w lochu „ustawnie błogosławionego Gaudencyusza wzywał, aby go swoją świętą przyczyną u Pana Boga z onego więzienia wybawił". Mamy tu zatem do czynienia ze świadomym czcicielem, który wiedział przez czyje pośrednictwo kierować swe błagania do Najwyższego i za ową niezachwianą wiarę tudzież stałość w nadziei został wynagrodzony spełnieniem jego prośby. Najbardziej frapujący jest jednak sam koniec owej opowieści w wersji Pruszcza, z którego dowiadujemy się, że ów więziony niegdyś (choć z tekstu Fortecy duchownej nie sposób dowiedzieć się wprost gdzie, przy czym informacja, że był to „student z Pragi”, pośrednio zdawałaby się wskazywać na stolicę Czech) młodzieniec został później arcybiskupem gnieźnieńskim, a zatem którymś z rzędu następcą swojego wybawiciela! Z kolei S. Szczygielski, K. Niesiecki i F. Jaroszewicz utrzymują, że ów Tomasz, którego imię i oni powtarzają, został - kolejno - kanonikiem, dziekanem i na koniec arcybiskupem praskim, co już nijak nie sposób pogodzić z chronologią wydarzeń, bo wszak Praga stolicą arcybiskupią była dopiero od r. 1344!

Otóż asumpt dla tego rodzaju dziwacznych konstrukcji dał w sposób pośredni nie kto inny, lecz sam Václav Hájek, który całą ową opowieść rozpoczyna od słów: „Přihodilo se, že mládenec jeden od kostela sv. Víta na hradě pražském ze školy, jemuž było jméno Kozmas, kterýž potom děkanem i biskupem był téhož kostela, stoje v kostele před altářem ss. Kozmy a Damiana, rríkal žaltař”, itd. ${ }^{132}$. Żyjący w XVI w. autor pomieszał tedy ze sobą postaci sprzed kilku stuleci, mianowicie pierwszego kronikarza czeskiego Kosmasa, który faktycznie był dziekanem kapituły katedralnej w Pradze, oraz zmarłego w r. 1098, z zatem współczesnego poprzedniemu, tegoż imienia biskupa praskiego, rządzącego diecezją od r. 1091 (1094). Widniejący wyżej ciąg: kanonik - dziekan - biskup, staje się więc zrozumiały, że zaś w XVII w. Praga była już od dawna stolicą arcybiskupią i ówcześni polscy dziejopisowie niekoniecznie musieli się orientować, od jak dawna istniało to arcybiskupstwo, stąd też Tomasz z biskupa stał się arcybisku-

${ }^{131}$ Václava Hájka z Libočan Kronika česká, t. 2, s. 379-380 (,Zázrak sv. Radima”).

${ }^{132}$ Tamże, t. 2, s. 379. 
pem. Czy Pruszcz był zatem lepiej zorientowany i wiedząc, że w odniesieniu do lat siedemdziesiątych XI w. nie można mówić o archidiecezji praskiej, uczynił bohatera arcybiskupem gnieźnieńskim, wydaje się więcej aniżeli wątpliwe. Jeśli by odznaczał się tego rodzaju erudycją, to chyba bez trudu mógłby stwierdzić, że w poczcie arcypasterzy Kościoła gnieźnieńskiego nie było nigdy (zresztą po dziś dzień) żadnego Tomasza (nota bene nie znamy też biskupa czy arcybiskupa Pragi o tym imieniu). Możemy zatem przypuszczać, że było to takież samo zmyślenie, jak i w pozostałych ukazanych tu punktach, składających się na listę rozbieżności w stosunku do oryginalnej opowieści Kosmasa. Najbardziej jednak dyskredytujący jest fakt, że Pruszcz i w ślad za nim kontynuatorzy pomylili autora relacji z bohaterem opowieści, bo przecież V. Hájek wyraźnie stwierdza, że to Kosmas został biskupem praskim, a nie ów niewiadomego imienia człowiek, który przybył złożyć wotum do grobu bł. Radzima-Gaudentego.

Tak obszerna dygresja odnośnie do owej fikcji historiograficznej wydawała się tu konieczna, by na konkretnym przykładzie ukazać, jak rodzi się powtarzana przez kolejnych autorów i przenikająca do świadomości szerszego kręgu czytelników ich dzieł legenda, która jeśli doczeka się spopularyzowania, może się okazać zgoła nie do wykorzenienia. Przechodząc zaś do dwóch pozostałych dzieł z lat sześćdziesiątych XVII w., jakie zamierzamy tu uwzględnić, to oba one wyszły spod pióra uczonego benedyktyna tynieckiego Stanisława Sczygielskiego vel Szczygielskiego (1616-1687), późniejszego opata w Trokach na Litwie, którego najbardziej znaną pracą jest Tinecia seu historia monasterii Tinecensis $(1668)^{133}$. Nas interesować tu będą wszakże inne jego publikacje, mianowicie Aquila Polono-Benedictina i Calendarium Benedictinum - obie wydane w Krakowie w roku 1663. W drugiej z wymienionych bł. Radzimowi-Gaudentemu poświęcona została tylko zwięzła notka (jak na kalendarz liturgiczny przystało), pod datą 29 V („IV Calendas Junii”), o brzmieniu: „Gaudentii, archiepiscopi et confessoris Gnesnensis, Ungarorum apostoli" ${ }^{\prime 34}$. W owej zapisce zastanawia tak dobitne wyeksponowanie roli rzeczonego duchownego w pracy chrystianizacyjnej wśród Węgrów, o której wszak de facto niewiele wiemy i w której był przecież tylko towarzyszem swego przyrodniego brata, św. Wojciecha. Już chyba bardziej uprawnione, choć tylko w charakterze domysłu, byłoby nazwanie Gaudentego „apostolus Polonorum”, bo jako pierwszy arcybiskup gnieźnieński bez wątpienia niemało trudu musiał włożyć w swą posługę na ziemiach państwa Piastów (inna rzecz, że nie trwała ona długo), a przede wszystkim działał już samodzielnie (nie w rozumieniu, iż w pojedynkę, lecz jako pasterz i przewodnik, nie zaś współpracownik lub pomocnik).

Więcej szczegółów o bł. Radzimie-Gaudentym znajdujemy w dziele Aquila Polono-Benedictina, w którym hierarcha ów nie mógł zostać pominięty, bo wszak zaliczał się do duchowych synów św. Benedykta z Nursji, przywdziawszy niegdyś benedyktyński habit w opactwie śś. Bonifacego i Aleksego w Rzymie

${ }^{133}$ HNP, t. 6, s. 674; Słownik historyków polskich, s. 507.

${ }^{134}$ S. Sczygielski, Calendarium Benedictinum e menologio sanctorum, beatorum atque illustrium eiusdem Ordinis virorum, excerptum, in quo celebriorum Instituti Benedictini personarum nominatenus, per dies singulos, anni totius, breviter recensentur, Cracoviae 1663, s. 110. 
na Awentynie. Tu również o tymże arcybiskupie czytamy pod datą $29 \mathrm{~V}$ („IV Calendas Junii”), gdzie odnotowano, iż „Gnesnae in Polonia” przypada tego właśnie dnia wspomnienie liturgiczne „beati Gaudentii, archiepiscopi Gnesnensis et confessoris" ${ }^{135}$. Dalej jednak wyczytujemy, że ów przyrodni brat św. Wojciecha „monachum in Brzevnoviensi Boemiae monasterio Ordinis Sancti Benedicti professus est"136, co stoi w sprzeczności z zawartym w świętowojciechowych żywotach świadectwie o jego wstąpieniu do zakonu w Wiecznym Mieście, a przede wszystkim faktem, że opactwo brzewnowskie ufundowane zostało dopiero w r. 992/993 i obsadzone mnichami przybyłymi najprawdopodobniej właśnie z rzymskiego klasztoru śś. Aleksego i Bonifacego. O najbardziej interesującej nas kwestii czasu i okoliczności powołania Radzima-Gaudentego na stolicę arcybiskupią w Gnieźnie S. Sczygielski pisze krótko: „In Poloniam quoque accitus, ab eodem [sancto] Adalberto metropolitanus Gnesnensis ordinatus [est]", a zatem w zgodzie ze starszą historiografią, dodając następnie: „Hoc ex Menologio Benedictino et Dubravio referimus"137 (o XVI-wiecznym dziele Historia Bohemica biskupa ołomunieckiego Jana Dubraviusa mowa była już wcześniej). Kolejne zdanie w Aquilii Sczygielskiego rozpoczyna się od słów: „Ex historicis autem Polonicis de hoc beato Gaudencio constat" (itd.), po czym mowa jest o zjeździe gnieźnieńskim i koronowaniu wówczas Bolesława I Chrobrego na króla ${ }^{138}$. Benedyktyński autor wskazuje także na znajomość analizowanej powyżej kroniki czeskiej Vaclava Hájka' ${ }^{139}$, podobnie jak odwołuje się do Bartosza Paprockiego i Antonio Bonfiniusa (1427-1502/1503) $)^{140}$. W tym ostatnim przypadku chodzi o dzieło Historia Pannonica sive Hungaricarum rerum decades, którego pierwsze pełne wydanie ukazało się w r. 1568, gdzie rzeczywiście natrafić można na informacje także o Radzimie-Gaudentym. Wprawdzie w opisie przybycia na Węgry św. Wojciecha jego przyrodni brat nie został wspomniany z imienia (tylko ogólnego charakteru informacja, że późniejszy męczennik przybył tu „cum sacerdotibus") ${ }^{141}$, niemniej tam, gdzie mowa jest z kolei o opuszczeniu przezeń państwa Arpadów i jego wyprawie do Prus, czytamy o późniejszym arcybiskupie gnieźnieńskim (w zgodzie ze świadectwem świętowojciechowych żywotów), że był uczestnikiem tej tragicznej w swym przebiegu akcji misyjnej ${ }^{142}$. S. Sczygielski

${ }^{135}$ S. Sczygielski, Aquila Polono-Benedictina, in qua beatorum et illustrium virorum elogia, caenobiorum ac rerum memorabilium synopsis, exordia quoque et progressus Ordinis D.P. Benedicti per Poloniam et eius sceptris subiectas provincias breviter describuntur [...], Cracoviae 1663, s. 54.

${ }^{136}$ Tamże, s. 54.

137 Tamże, s. 55.

${ }^{138}$ Tamże, s. 55.

${ }^{139}$ Tamże, s. 55 („Venceslaus Haiek, Boemorum historicus, de hoc beato refert”, itd.).

${ }^{140}$ Tamże, s. 56 („videatur etiam Bonfinius et Paprocki”).

${ }^{141}$ Antonii Bonfinii Historia Pannonica sive Hungaricarum rerum decades IV. et dimidia libris XLV. comprehensae [...], Coloniae Agrippinae 1690, s. 114-115 (w wcześniejsze wydania).

${ }^{142}$ Tamże, s. 117 (m.in.: „Liboniam ingressus, dum obstinatos efferarum gentium animos vero Dei molliri contendit, ecce Gaudentius, alter e comitibus, in somnis inter sacrificandum custodem altaris rogasse ipsi sibi visus est, an totum calicem in ara situm, sibi haurire fas esset. Contra custodem renuentem respondisse, calicem pontifici Pragensis esse destinatum, eum totum poculum hau- 
pisze także na końcu o zrabowaniu ciała bł. Radzima-Gaudentego podczas najazdu księcia Brzetysława I, w tej części swej narracji wskazując znów na kronikę Macieja Karpigi z Miechowa ${ }^{143}$. Wcześniej przytoczył natomiast znaną nam już opowieść o cudzie dokonanym pośmiertnie przez niegdysiejszego metropolitę gnieźnieńskiego, zaczerpniętą z kroniki Václava Hájka z Libočan. Co ciekawe, bardzo precyzyjnie datuje ów fakt na dzień 7 VI 1071, pisząc, że bohaterem owego wydarzenia był niejaki „,Thomas, nobilis adolescens Pragensis”, który „cum esset in studiis” dopuścił się jakiegoś przewinienia („,ob quoddam conflictum crimen”) i został wtrącony do karceru - znów bez żadnej wzmianki, że miejscem uwięzienia miał być Kraków ${ }^{144}$. Dopiero piszący w wiek później o. Florian Jaroszewicz zbierze łącznie wszystkie te informacje i wyciągnie z nich wniosek, że tym cudownie uwolnionym był „Tomasz z Pragi, student w Krakowie, o pewien kryminał do więzienia wtrącony"145. Była już natomiast mowa, że odmiennie, aniżeli P.H. Pruszcz, S. Sczygielski uznał, że ów czciciel bł. Radzima-Gaudentego został później - kolejno - kanonikiem, dziekanem i na koniec arcybiskupem praskim, na wszystkich tych szczeblach kariery kościelnej rozgłaszając sławę swego niegdysiejszego wybawiciela i gorliwie propagując jego kult ${ }^{146}$.

Dokładnie w dziesięć lat po ukazaniu się drukiem obu dzieł Stanisława Sczygielskiego, tj. w roku 1673, powstał istotny z punktu widzenia naszej analizy traktat De archiepiscopatu Gnesnensi autorstwa Andrzeja Olszowskiego (16211677). To skądinąd niepokaźne dzieło bez wątpienia zasługuje na uwagę nie tylko ze względu na jego tematykę, ale nie mniej fakt, że wyszło spod pióra duchownego, który sam zasiadał w latach 1674-1677 na stolicy metropolitalnej w Gnieźnie (poprzednio ordynariusz chełmiński i podkanclerzy koronny), będąc zatem dalekim następcą bł. Radzima-Gaudentego ${ }^{147}$. Traktat ów nie został wszakże opublikowany za życia prymasa Olszowskiego, lecz wraz z trzema jeszcze komplementarnymi rozprawami De legatione nata, De archiepiscopi Gnesnensis primatu i De primo principatu archiepiscopi Gnesnensis, tworzącymi w łącznym ujęciu pewną logiczną całość, doczekał się druku w r. 1709 za sprawą siostrzeńca rzeczonego hierarchy, samemu też należącego do grona episkopatu Rzeczypospolitej

rire oportere. Quod quidem somnium quum Adalberto retulisset, intellexit patet ille sanctissimum, optatissimi sibi martyrii tempus imminere. Sexto post die quum Gaudentius coram eo rem sacram fecisset, hic sacris rite peractis secessum petiit, ut membra aliquantulum fessa relaxaret, inter dormiendum ecce impiorum multitudo confluxit, qui circumventum interpidumque capiunt, vinculis obligant, efferunt in iugum montis, paloque alligatum septem lanceis corpus effodiunt [...]" (itd.). Por. W kręgu żywotów świętego Wojciecha, s. 74-75, 126-127. Także Labuda, Nad legenda o św. Wojciechu, s. 19-20.

${ }^{143}$ Sczygielski, Aquila Polono-Benedictina, s. 56-57.

${ }^{144}$ Tamże, s. 53-54.

${ }^{145}$ Jaroszewicz, Matka świętych Polska, s. 276 (w XIX-wiecznym wydaniu - s. 334).

${ }^{146}$ Sczygielski, Aquila Polono-Benedictina, s. 54.

${ }^{147}$ M.in. Estreicher, Bibliografia polska, t. 23, s. 341-348; HNP, t. 6, s. 475-476; W. Czapliński, Olszowski Andrzej herbu Prus (1621-1677), biskup chelmiński, podkanclerzy koronny, prymas, PSB, t. 24, s. 42-46; SPTK, t. 3, s. 250-253 (E. Ozorowski); Prokop, Arcybiskupi gnieźnieńscy, s. 228-231; K. Śmigiel, Stownik biograficzny arcybiskupów gnieźnieńskich i prymasów Polski, Poznań 2002, s. 220-225. 
Obojga Narodów Andrzeja Chryzostoma Załuskiego, wówczas biskupa warmińskiego ${ }^{148}$. Mimo to omawiamy go (czy w zasadzie je, bowiem także w traktacie De archiepiscopi Gnesnensis primatu natrafiamy na interesujące nas informacje) w ramach przeglądu XVII-wiecznego piśmiennictwa historycznego, niewątpliwie bowiem ważniejsza jest w tym kontekście data powstania dzieła, aniżeli jego wydania (wszak i w przypadku spuścizny Jana Długosza długo pozostawał ona dostępna tylko w postaci rękopiśmiennej).

Pisząc o arcybiskupstwie gnieźnieńskim w ujęciu prawno-historycznym, Andrzej Olszowski nie mógł pominąć kwestii czasu i okoliczności jego powstania. W owym kontekście stwierdza on co następuje: „Excellentia haec archiepiscopi, in cunabulis nascentis orthodoxae religionis in Regno, circa annum post Christum natum 966 originem cepit, cum Gnesnensem basilicam a Miecislao, primo Polonorum principe Christiano, erectam et fundatam Aegidius, cardinalis episcopus Tusculanus, Joannis Papae XIII. nuntius a latere, in metropolitana ordinasset" ${ }^{149}$. Dalej przytacza też in extenso co na ów temat pisze Marcin Kromer w De origine et rebus gestis Polonorum, a więc o istniejących rzekomo już w drugiej połowie X w. arcybiskupstwach gnieźnieńskim i krakowskim oraz biskupstwach poznańskim, smogorzowski, kruszwickim, płockim, chełmińskim, lubuskim i kamieńskim. Szczególny akcent (również poprzez wyróżnienie większym krojem czcionki) kładzie wszakże na świadectwo, które neguje rangę Krakowa, jako „konkurencyjnego” w stosunku do Gniezna arcybiskupstwa („Anonymus quidam vetustus, rerum Polonicarum annotator, verius quam scriptor, Cracoviae quoquae initio non archiepiscopum sed episcopum vult esse constitutum, deinde vero Aaronem, abbatem Tinecensem, a Benedicto Papa V. primum archiepiscopum Cracoviensem renuntiatum esse, eam vero praerogativam, successorem eius proximum Lambertum Zulam, neglexisse") ${ }^{150}$. Skoro zatem A. Olszowski datuje początki stolicy metropolitalnej w Gnieźnie jeszcze na czasy chrztu Mieszka I, nic zatem dziwnego, że nie wspomina w tym kontekście o bł. Radzimie-Gaudentym, jako o pierwszym arcybiskupie gnieźnieńskim. Postać ta była mu wszakże znana, czego dowód dał z kolei w rozprawie De archiepiscopi Gnesnensis primatu. Tam, omawiając prerogatywy metropolitów Gniezna, jako prymasów, zestawił wykaz dotychczasowych koronacji królów polskich, w którym też wskazał na poszczególnych koronatorów. Na samym początku owego zestawienia czyta-

${ }^{148}$ A. Olszowski, De archiepiscopatu Gnesnensi, w: Andreae Chrysostomi in Zatuskie Zatuski, primo Kiioviensis, postea Plocensis et nunc Varmiensis episcopi, Sacri Romani Imperii principis, terrarum Prussiae praesidis et supremi Regni Poloniae cancellarii, Epistolarum historico-familiarum tomus primus, a morte Ludovicae reginae et abdicatione regis Joannis Casimiri, regum Michaelis I. et Joannis III. acta continens, Brunsbergae 1709, s. [721]-[740]; A. Olszowski, De legatione nata, w: Andreae Chrysostomi in Zatuskie Zatuski, primo Kiioviensis, postea Plocensis et nunc Varmiensis episcopi, s. [740]-[779]; A. Olszowski, De archiepiscopi Gnesnensis primatu, w: Andreae Chrysostomi in Zatuskie Zatuski, primo Kiioviensis, postea Plocensis et nunc Varmiensis episcopi, s. [779]-[808]; A. Olszowski, De primo principatu archiepiscopi Gnesnensis, w: Andreae Chrysostomi in Zatuskie Zatuski, primo Kiioviensis, postea Plocensis et nunc Varmiensis episcopi, s. [809]-[836].

${ }^{149}$ Olszowski, De archiepiscopatu Gnesnensi, s. [721].

${ }^{150}$ Tamże, s. [721] (za M. Kromerem). 
my: „Boleslaum primum, Ottone III. Imperatore praesente et coronam imponente, Gaudentius archiepiscopus concoronavit, cui solemnitati aderat Silvestri II. Papae legatus de latere [Robertus], diaconus cardinalis, anno 1000"151. Widzimy zatem, że i ten autor uznał za rzecz nie ulegającą wątpliwości dopełnienie koronacji Bolesława I Chrobrego podczas tzw. zjazdu gnieźnieńskiego, przypisując tu eksponowaną rolę Radzimowi-Gaudentemu.

O wiele dłużej, aniżeli wyliczone powyżej traktaty prawno-historyczne Andrzeja Olszowskiego, czekały na druk powstałe po roku 1680 Żywoty arcybiskupów gnieźnieńskich Stanisława Bużeńskiego († 1692), wedle oceny J. Korytkowskiego „oryginalnie napisane”. Jak też zauważa ów badacz, „dzieło ks. Bużeńskiego nie było znane aż do roku 1755, w którym dopiero ogłaszać je począł w języku niemieckim w skróceniu Wawrzyniec Mizler de Kolof w «Bibliotece Warszawskiej» [...], w całości zaś w języku łacińskim w «Aktach literackich» żywoty od Wilibalda aż do Jana Tarnowskiego"152. Już z samego przytoczonego tu cytatu można zatem wywnioskować, iż rzeczony XVII-wieczny historyk i prałat (przez pewien czas sekretarz prymasa Wacława Leszczyńskiego, którego osobną biografię napisał) swój zbiór życiorysów pasterzy Kościoła gnieźnieńskiego rozpoczyna od Wilibalda („Villibalin czyli Villibaldus Francuz”), a bł. RadzimaGaudentego kładzie dopiero na piątym miejscu, po św. Wojciechu. Jak też czytamy w polskojęzycznym wydaniu tychże żywotów z roku 1860, „Gaudenty, w ojczystym czeskim czy też sławiańskim języku zwał się Radzynem. Był bratem rodzonym św. Adalberta i za życia jeszcze świętego męczennika, kiedy ten do Prus się udał na przepowiadanie poganom Ewangelii, objął rządy kościoła metropolitalnego w roku 992 [sic], to jest tym samym, w którym brat jego męczeństwem życia dokonał. Za jego czasów przypadła śmierć Mieczysława, pierwszego z monarchów polskich po przyjęciu wiary chrześcijańskiej ${ }^{153}$. I dalej: „Arcybiskup Gaudenty, za radą czy też rozkazem cesarza Ottona [...], który [...] przybył do Gniezna dla zwiedzenia grobu św. [Wojciecha], ozdobił królewskim dostojeństwem Bolesława Chrobrego [...], a sam cesarz dał złotą koronę i wśród świetnej, na ten cel przygotowanej uroczystości, sam ją na głowę Bolesława włożył. Za jego też czasów ciało św. Adalberta z Trzemeszny przeniesiono do Gniezna, oraz pięciu braci kamedułów [...] męczeńską śmiercią życia dokonało" ${ }^{154}$. Wreszcie na sam koniec niezbyt tedy obszernego curriculum vitae tegoż hierarchy S. Bużeński

${ }^{151}$ Olszowski, De archiepiscopi Gnesnensis primatu, [784]. Całość wykazu: s. [783]-[785].

152 J. Korytkowski, Prałaci i kanonicy katedry metropolitalnej gnieźnieńskiej od roku 1000 aż do dni naszych, t. 1, Gniezno 1883, s. 117. Do biografii Stanisława Bużeńskiego zob. Korytkowski, Prałaci i kanonicy, t. 1, s. 114-119; Estreicher, Bibliografia polska, t. 13, s. 474-475; K. Piwarski, Bużeński Stanisław herbu Poraj († 1692), PSB, t. 3, s. 157-158; HNP, t. 6, s. 72; SPTK, t. 1, s. 262263 (E. Ozorowski); T. Oracki, Stownik biograficzny Warmii, Prus Ksiązęcych i Ziemi Malborskiej od połowy XV do końca XVIII wieku, Olsztyn 1984, s. 31; Słownik biograficzny kapituly warmińskiej, oprac. zbior., Olsztyn 1996, s. 30-31 (A. Kopiczko).

${ }^{153}$ Żywoty arcybiskupów gnieźnieńskich, prymasów Korony Polskiej i Wielkiego Księstwa Litewskiego, od Wilibalda do Andrzej Olszowskiego włacznie, opisat Stanisław Bużeński, dziekan i oficjał warmiński, kanonik gnieźnieński i krakowski, przeł. M. Bohusz Szyszko, uzup. i wyd. M. Malinowski, t. 1, Wilno 1860, s. 32.

${ }^{154}$ Tamże, t. 1, s. 32-33. 
stwierdza: „Arcybiskup Gaudenty, bratniej świątobliwości i urzędu jego sukcesor, po upływie lat siedmiu, a według Długosza dziewięciu, w Gnieźnie życia dokonał i tamże, w kościele metropolitalnym, pogrzebiony [został]. Czytamy w Długoszu, że przed śmiercią rzucił klątwę na miasto Gniezno za to, że mnóstwa dopuszczało się występków i na jego napomnienia nie pokutowało. Klątwa ta nie była rzucona na próżno, gdyż Czesi niebawem [...] rozlewem krwi i łupiestwem spustoszyli Gniezno i metropolitalny kościół. Śmierć jego, według Długosza, Paprockiego i spisu arcybiskupów gnieźnieńskich, który jest u mnie pod ręką, napisany staroświeckim charakterem, przypadła na rok $1006 " 155$. Dla porządku należy też odnotować, że cytowany tu XVII-wieczny historiograf wspomina nadto o bł. Radzimie-Gaudentym także w życiorysie arcybiskupa Bossuty, właśnie przy opisie najazdu Brzetysława I ${ }^{156}$, oraz oczywiście w żywocie św. Wojciecha, jako rzekomego pasterza Kościoła gnieźnieńskiego ${ }^{157}$.

V.

Jak przegląd XVII-wiecznego piśmiennictwa zakończyliśmy dziełem wydanym drukiem dopiero $\mathrm{w}$ wiele dziesięcioleci po jego powstaniu, tak też analizę zabytków rodzimej historiografii z kolejnego stulecia pod kątem obecności w nich wątków odnoszących się do bł. Radzima-Gaudentego rozpoczniemy od opracowania, którego losy można uznać za podobne. Mowa o kompendium Ad historiam ecclesiasticam Pomeraniae apparatus przeora kartuzji kaszubskiej na Pomorzu Jerzego Schwengla (1697-1766), uczonego i prawdziwie niestrudzonego w swej pasji zgłębiania przeszłości erudyty. Rzeczone opracowanie opatrzone jest datą 1749, jednakże wydania doczekało się dopiero w latach 1912-1915 158 . Przynosi ono zebrane w jednym tomie materiały do dziejów kościelnych Pomorza Nadwiślańskiego - przede wszystkim w formie wypisów z wcześniejszych dziejopisarzy oraz wówczas jeszcze nie nazbyt licznych edycji źródłowych. Nie zabrakło też na początku rozdziału ogólnego De religionis Christianae in Polonia initiis, na który składają się właśnie zestawione ze sobą fragmenty (czy też wyimki) z nowożytnych zabytków piśmiennictwa historiograficznego, jak i ze śred-

${ }^{155}$ Tamże, t. 1, s. 33.

156 Tamże, t. 1, s. 40-41 („Gaudentego ciało zabrał i razem z Pięcioma Świętymi Braćmi do Czech z sobą uwiózł").

${ }^{157}$ Tamże, t. 1, s. 16, 22, 24, por. s. 30-31. Szczególnie interesujący (ze względu na dodatek w nawiasie) jest passus na s. 24, gdzie czytamy, iż św. Wojciech, „chcąc rozszerzyć pomiędzy [Prusami] światło wiary, powierza urząd arcybiskupi [w Gnieźnie] bratu swemu Gaudentemu czyli Radzynowi, dotąd towarzyszowi wszystkich swych podróży (jakowe ustępstwo bez wątpienia zatwierdzone zostało przez Ojca Świętego), a sam, z kilku zakonnikami św. Benedykta czyli św. Romualda reguły, pomimo oporu książąt i ludu [...], udaje się w niebezpieczną podróż”.

158 Ad historiam ecclesiasticam Pomeraniae apparatus pauper subsidia literaria poscens a viris bonis et doctis collectus ad interim a Georgio Schwengel, Cartusiae priore, 1749, cur. B. Czapla (Towarzystwo Naukowe w Toruniu. Fontes, t. XVI-XIX), Torunii 1912-1915. Zob. ostatnio R. Witkowski, Jerzy Schwengel (1697-1766) - przeor kartuzji kaszubskiej i dziejopis Kościoła, Poznań 2004, s. 134-135. 
niowiecznych źródel ${ }^{159}$. Ograniczając się tu - stosownie do zakresu naszej analizy - wyłącznie do kręgu polskiej historiografii, kolejno przywołane zostały przez J. Schwengla De origine et rebus gestis Polonorum M. Kromera, Historia Polonica (czyli Annales) J. Długosza (po czym informacja, że z ich „wersją” wydarzeń zgadzają się także Miechowita, Bielski, Herburt, Stryjkowski i Starowolski, którzy też już nie są cytowani), Chronica Polonorum mistrza Wincentego (w tym przypadku dla porównania sięgnięto m.in. do Thietmara i św. Piotra Damianiego) oraz Vitae et series episcoporum Plocensium S. Łubieńskiego. Spożytkowana została również świeżej wówczas daty edycja źródłowa Silesiacarum rerum scriptores wrocławianina Friedricha Wilhelma Sommersberga (1698-1756), podobnie jak i wydane już wtedy drukiem Annales Magdeburgenses (także Annalista Saxo), a wreszcie też Annales ecclesiastici Cesare Baroniusza. Mamy tu zatem przytoczone wszystko, co widnieje tamże na temat pierwocin organizacji diecezjalnej na ziemiach polskich, a prócz tego J. Schwengel sięga także do znanych nam już Sarmatiae bellatores Szymona Starowolskiego oraz wydanej w roku 1618 kompilacji Historia rerum Polonicarum Salomona Neugebauera, pochodzącego z Prus i wykształconego na uczelniach niemieckich rektora szkoły kalwińskiej w Kocku ${ }^{160}$ (ten ostatni autor także pisze o założeniu jakoby za Mieszka I arcybiskupstw w Gnieźnie i Krakowie oraz biskupstw w Poznaniu, Smogorzewie, Kruszwicy, Płocku, Chełmży, Lubuszu i Kamieniu Pomorskim, zaś w odniesieniu do zjazdu gnieźnieńskiego wzmiankuje, że odbyła się wówczas koronacja Bolesława I Chrobrego „Gaudentio archiepiscopo solennes ceremonias peragente") ${ }^{161}$. Zgadza się też z nimi kartuski historiograf co do początków diecezji kruszwickiej, w kolejnym rozdziale, zatytułowanym De erectione cathedrae Crusviciensis, swój wywód zaczynając od słów: „Sat superque ex praemissis docemur, ecclesiam Crusviciensem adeoque et episcopatum Cuiaviensem primum fundatorem ac dotatorem habuisse Miecislaum I. monarcham Poloniae" (po czym dalej kontynuuje dywagacje w tym duchu, powołując się na S. Damalewicza i pisząc o legacji do Polski kardynała Idziego vel Egidiusza) ${ }^{162}$. Nadzwyczaj pomysłowo poradził sobie J. Schwengel z nieprzystającym wszak do tamtych wywodów świadectwem kroniki Thietmara, z której wywnioskował, że w roku 1000 powstało nadto biskupstwo w Kołobrzegu (tylko o tym jednym wspomina

${ }^{159}$ Nie sposób nie wspomnieć w tym miejscu, że J. Schwengel pozostawił również analogicznego rodzaju zbiór zatytułowany Ad historiam ecclesiasticam Poloniae apparatus (z roku 1754), który wszakże pozostaje wciąż niewydany, przy czym jego rękopis znajduje się w Archiwum Diecezjalnym w Pelplinie. Zawarte są w nim m.in. takie rozdziały, jak Proprium sanctorum Regni Poloniae, Status ecclesiasticus Regni Poloniae, Episcopi Regni Poloniae ad annum 1744 czy Cathedrae Regni Poloniae. Zob. W. Brauer, Einleitung zu den Werken des Dom Georgius Schwengel (Analecta Cartusiana, vol. 90), Salzburg 1982, s. 26 nr 27 (także nr 26); Witkowski, Jerzy Schwengel, s. $135-136$.

${ }^{160}$ Ad historiam ecclesiasticam Pomeraniae apparatus, s. 5-11.

${ }^{161}$ Historia rerum Polonicarum concinnata et ad Sigismundum Tertium, Poloniae Sveciaeque regem usque deducta. Libris decem a Salomono Nengebauero a Cadano, Hanoviae 1618, s. 51 (rozdział Mieczislaus Primus princeps Christianus), 53 (rozdział Boleslaus Primus cognomento Chrobri).

${ }^{162}$ Ad historiam ecclesiasticam Pomeraniae apparatus, s. 12 nn. (o tym także na s. 17). 
w owym kontekście) i zostało wtedy podporządkowane istniejącej już od dawna stolicy metropolitalnej w Gnieźnie ${ }^{163}$. Dla kompletności trzeba też wspomnieć, że historiograf ten znał również zabytki piśmiennictwa odnoszące się do osoby św. Wojciecha, i opisując jego wyprawę misyjną do Prus oraz śmierć męczeńską w rozdziale De conversione Gedanensium, przytacza fragment żywotu, gdzie bł. Radzim-Gaudenty wymieniony jest jako uczestnik tragicznej misji pruskiej („,remansit [Adalbertus] cum geminis fratribus, quorum alter presbyter Benedictus, alter dilectus et a puero sibi comes frater Gaudentius erat") ${ }^{164}$, co wszak wielu innych autorów przeoczyło.

Lektura materiałów pozostawionych przez Jerzego Schwengla wzbudza tedy mieszane uczucia, $\mathrm{z}$ jednej bowiem strony był on bez wątpienia erudytą i zarazem starał się nie zlekceważyć żadnego świadectwa (stąd nie mamy tutaj do czynienia np. z tego rodzaju „naśmiewaniem się” z Thietmara, jak u S. Łubieńskiego), z drugiej jednak wszystko wrzucił do jednego „worka”, zbytnio też w nim nie przebierając, lecz jakby zgoła radując się z tej mnogości świadectw i z każdego starając się wyciągnąć jakichś pożytek dla swej wiedzy o przeszłości, a wszak nie każde $\mathrm{z}$ nich na to zasługiwało ${ }^{165}$. Mimo to na tle sobie współczesnych i tak wyróżniał się in plus, co widać chociażby przy porównaniu z kilkakrotnie już tu przywoływanym o. Florianem Jackiem Jaroszewiczem (ok. 1694-1771) z gałęzi reformackiej Zakonu Braci Mniejszych (franciszkanów) ${ }^{166}$. Jego Matka świętych Polska to dzieło raczej mało krytyczne, jako że autor ten niemal całkowicie zdał się na autorytet tworzących przed nim historiografów i hagiografów, nie siląc się zbytnio na jakieś własne dociekania, zmierzające ku odrzuceniu przekazów nie zasługujących na wiarę (wyjątek, to owa kontrowersyjna kwestia zrabowanych z Gniezna relikwii, o czym niżej). Nie inaczej rzecz przedstawia się w odniesieniu do bł. Radzima-Gaudentego, którego żywot - jak sam wskazuje - oparł m.in. na Długoszu, Bonfiniuszu i Menologium Benedictinum ${ }^{167}$. Znajdziemy zatem u niego niewiele więcej ponad to, co u Pruszcza i Sczygielskiego, choć za tym ostatnim nie powtarza, jakoby późniejszy arcybiskup był profesem brzewnowskim. O okolicznościach osadzenia Radzima na stolicy metropolitalnej w Gnieźnie F. Jaroszewicz pisze: „A że św. Wojciech za natchnieniem Ducha Świętego obrócił się do nawracania pogaństwa w Prusiech, temu bratu swemu Gaudencyuszowi w rząd polecił arcybiskupstwo gnieźnieńskie, przydawszy mu dwóch kapłanów:

163 Tamże, s. 20 (rozdział De conversione Pomeranorum - s. 19-26).

${ }^{164}$ Tamże, s. 17-19. Mamy tu do czynienia z dosłownym cytatem z jednego ze współczesnych żywotów św. Wojciecha (Świętego Wojciecha, biskupa i męczennika, żywot pierwszy, s. 41: „remansit ibi cum geminis fratribus, quarum alter presbiter Benedictus, alter dilectus et a puero sibi comes frater Gaudentius erat").

${ }^{165}$ Ogólnie o J. Schwenglu i jego spuściźnie piśmienniczej zob. ostatnio: Słownik biograficzny Pomorza Nadwiślańskiego. Suplement I, red. Z. Nowak, Gdańsk 1998, s. 276 (W. Odyniec); Witkowski, Jerzy Schwengel, passim.

${ }^{166}$ M.in. Estreicher, Bibliografia polska, t. 18, s. 491-492; HNP, t. 6, s. 275; SPTK, t. 2, s. 186-188 (A. J. Szteinke).

${ }^{167}$ F. Jaroszewicz, Matka świętych Polska, s. 275-276 (,Żywot błogosławionego Gaudencyusza albo Radzina, arcybiskupa gnieźnieńskiego"). Także XIX-wieczne wydanie: F. Jaroszewicz, Matka świętych Polska albo żywoty świętych, t. 2, s. 331-335. 
Christina y Papata. Po śmierci zaś y zamordowaniu św. Wojciecha, za naleganiem Mieczysława, monarchy polskiego (albo raczej podobno Bolesława Chrobrego, syna jego), od Grzegorza V. papieża Gaudencyusz na arcybiskupstwo gnieźnieńskie był wyniesiony i poświęcony" ${ }^{168}$. Trudno jednoznacznie rozstrzygnąć, czy to tylko pewna niezręczność sformułowania, czy też autor ten rzeczywiście uważał, iż Radzim-Gaudenty konsekrowany został na biskupa przez samego papieża (w tym przypadku Grzegorza V), a uprzednio tylko administrował archidiecezją (należy rozumieć - do czasu spodziewanego powrotu z Prus św. Wojciecha). Tego rodzaju „dodatków”, dowodzących nie tyle bogatszej wiedzy piszącego, co mniejszej u niego dbałości o szczegóły, wskazać zresztą można więcej. U F. Jaroszewicza czytamy też (zresztą nie u niego pierwszego) nie tylko o klątwie rzuconej na Gniezno, ale i o jakoby przepowiedzeniu przezeń jego zniszczenia przez księcia Brzetysława I (,,proroczym duchem opowiedział tę klęskę, którą na sobie poniosło to miasto, gdy go Bretysław, xiążę czeskie, y Severus, biskup praski, najechawszy złupili i do ostatniej prawie nędzy przyprowadzili") ${ }^{169}$. Podobnie jest $\mathrm{z}$ ową przywoływaną tu opowieścią o uwolnieniu za sprawą bł. RadzimaGaudentego uwięzionego człowieka, z którego autor Matki świętych Polski uczynił „studenta w Krakowie”, w karcerze kazał mu przebywać aż siedem lat (choć przecież u Kosmasa i w ślad za nim u Hájka mowa jest o trzech), widząc w nim oczywiście gorącego czciciela niegdysiejszego arcybiskupa Gniezna (,słysząc o wielkich cudach bł. Gaudencyusza, z płaczem mu niewolę swoją polecał"), wydarzenie tamto przypisał do daty 7 VI 1071 oraz ubarwił sam jego przebieg ${ }^{170}$. Co się tyczy jeszcze istotnych faktów, to śmierć Radzima-Gaudentego o. Jaroszewicz datuje na rok 1006 (,roku Pańskiego 1006 po zapłatę prac swoich przeniósł się do Pana"), pisze też o zabraniu w r. 1038 jego ciała przez Czechów rzekomo miast ukrytego ciała św. Wojciecha. Dowodzi przy tym, że nieprawdziwe jest twierdzenie, jakoby do Pragi uwieziono z Gniezna szczątki obu Sławnikowiców, bo „,przecież tylko jedno ciało w kaplicy daleko odsadzonej od kościoła katedralnego [na Hradczanach] prezentują, które że niewielką cześć ma u Czechów, pokazuje się stąd, że nie jest [to] ciało św. Wojciecha" (po czym wzmianka o wspomnianej już tu wcześniej rozmowie z cesarzem Ferdynandem I biskupa warmińskiego Marcina Kromera, który miał zwrócić temuż monarsze uwagę, że z pewnością bez trudu ,pozna gdzie prawdziwe jest ciało św. Wojciecha, gdy go bez ramienia i ręki znajdzie, bo to jest pewne i z brewiarza i ze św. Piotra Damianiego, że Ottonowi III. nawiedzającemu grób św. Wojciecha, za relikwię dał król Bolesław Chrobry z ciała jego ramię i rękę, które on bogato oprawne złożył w Rzymie [...]. W Pradze jest-ci wprawdzie ciało z Polski uwiezione i udają go za św. Wojciecha, ale że ma obydwie ręce i ramiona, toć nie może być św. Wojciecha") ${ }^{171}$.

${ }_{168}$ Jaroszewicz, Matka świętych Polska, s. 275 (w drugim wydaniu - s. 332).

169 Tamże, s. 276 (w drugim wydaniu - s. 332).

${ }^{170}$ Tamże, s. 276 (w drugim wydaniu - s. 334).

171 Tamże, s. 276 (w drugim wydaniu - s. 333-334). Co się tyczy jeszcze perypetii owych doczesnych szczątków, nieco wcześniej F. Jaroszewicz wspomina w żywocie bł. Radzima-Gaudentego, że on to właśnie „ciało św. Wojciecha, brata swego, z Trzemeszna do Gniezna przeprowadził” (s. 276; w drugim wydaniu - s. 333). 
O kilka lat wcześniej, aniżeli Matka świętych Polska, ukazał się w roku 1761 w Poznaniu pierwszy wolumin w sumie trzytomowego dzieła Vitae praesulum Poloniae, jezuity Franciszka Rzepnickiego (1710-1780), późniejszego archiwariusza prowincji wielkopolskiej swego macierzystego zakonu (nota bene jej ośrodkiem był Kraków) ${ }^{172}$. W pomieszczonym w owej edycji poczcie arcybiskupów Gniezna nie zabrakło oczywiście i św. Radzima-Gaudentego, choć zwyczajowo wymieniony on został dopiero na piątym miejscu, jako następca swego przyrodniego brata ${ }^{173}$. U F. Rzepnickiego nie ma już wszakże mowy o powierzeniu rządów w archidiecezji gnieźnieńskiej Radzimowi-Gaudentemu przez św. Wojciecha, lecz wyraźnie wskazano na udział młodszego ze Sławnikowiców w tragicznej wyprawie misyjnej do Prus i jego obecność przy męczeństwie późniejszego patrona polskiej prowincji kościelnej ${ }^{174}$. W owej zatem materii jezuicki historyk okazał wiarę świętowojciechowym żywotom i nie dał się zwieść niezgodnej z prawdą wizji losów bł. Radzima-Gaudentego, dominującej w staropolskim piśmiennictwie. Za Długoszem powtórzył niemniej błędnie, że ten to arcybiskup „Boleslaum Chrabry, ducem Poloniae, 1001 anno in regem unxit” (w poprzednim znów zdaniu czytamy, iż „corpus sancti fratris sui Tremesna Gnesnam transtulit”) i w ślad za nim przyjął też rok 1006 jako datę śmierci interesującej nas postaci (nie zabrakło również informacji o uwiezieniu w r. 1038 przez Czechów ciała arcybiskupa do Pragi) ${ }^{175}$.

Przy omawianiu XVIII-wiecznego piśmiennictwa nie sposób pominąć w naszym przeglądzie wydanej jeszcze w latach 1728-1743 czterotomowej Korony polskiej autorstwa innego jezuity - Kaspra Niesieckiego (1682-1744), który nad dziełem swym pracował w stanowiącym stolicę biskupów chełmskich Krasnymstawie. Był to kolejny - po edycjach B. Paprockiego i Sz. Okolskiego - herbarz obejmujący szlachtę z terytorium całej Rzeczypospospolitej Obojga Narodów, opracowany przy tym z dużym krytycyzmem i zawierający wiele cennego materiału faktograficznego, stąd też aż po współczesne nam czasy był on niejednokrotnie wznawiany, jakkolwiek nie w swej pierwotnej postaci, lecz w zmienionym i zarazem uzupełnionym, dziesięciotomowym wydaniu z lat 1839$1846^{176}$. Ów wychwalany w literaturze krytycyzm nie dopisał jednakowoż autorowi Korony polskiej przy tematyce najdawniejszych dziejów Polski, czemu zresztą

${ }^{172}$ M.in. Estreicher, Bibliografia polska, t. 26, Kraków 1915, s. 547-548; SPTK, t. 3, s. 545-546 (L. Grzebień); J. Kozłowski, Rzepnicki Franciszek (1710-1780), jezuita, historyk Kościoła, PSB, t. 34, s. 41; Encyklopedia wiedzy o jezuitach, s. 591.

${ }^{173}$ F. Rzepnicki, Vitae praesulum Poloniae [et] Magni Ducatus Lithvaniae res precipuae illorum temporibus gestae ad annum MDCCLX, origo ecclesiarum cathedralium quatuor libris comprehensae, t. 1, Posnaniae 1761, s. 39-40 („Radzinus seu Gaudentius de familia Rosinorum”).

174 Tamże, t. 1, s. 39.

${ }^{175}$ Tamże, t. 1, s. 39-40.

${ }^{176}$ Polska - dzieje i rzeczy jej rozpatrywane przez Joachima Lelewela, t. 1, s. 24 nr CX; Estreicher, Bibliografia polska, t. 23, s. 128-129; HNP, t. 6, s. 462; W. Dworzaczek, Niesiecki Kasper (1682-1744), jezuita, heraldyk, PSB, t. 23, s. 49-50; Stownik historyków polskich, s. 374; Dawni pisarze polscy, t. 3, s. 139 (I. Teresińska); Encykolpedia wiedzy o jezuitach, s. 457; I. M. Dacka, ,Korona polska” Kaspra Niesieckiego. Pomnik staropolskiego piśmiennictwa heraldycznego, Warszawa 2004 (tamże na s. 61-160 ogólnie o podstawie źródłowej Korony polskiej, w tym 
skądinąd trudno się dziwić. Wprawdzie więc i on przywołuje kronikę Thietmara, niemniej do jej świadectwa odnosi się nieufnie, przyznając też rację oponentom. K. Niesiecki stwierdza mianowicie: „Wszyscy się nasi historycy na to zgadzają, że z pierwiastkami wiary katolickiej rzymskiej w tem państwie, w roku 966, za Mieczysława, pierwszego z polskich monarchów chrześcijanina, dwie razem metropolie stanęły, to jest gnieźnieńska i krakowska, które potem Egidius, kardynał biskup tuskulański, legatus a latere Jana XIII, imieniem jego potwierdził. To pisze Kadłubek [!], Długosz, Kromer, Miechowita, Bielski, Neugebauer, Herburt, Stryjowski, Gwagnin, Orichivius [tj. Orzechowski], Damalewicz, Starowolski. Atoli Ditmarus dopiero być mieni postanowienie arcybiskupstwa gnieźnieńskiego od Ottona cesarza wtenczas, gdy po śmierci św. Wojciecha tego świętego męczennika grób nawiedzał, i przydaje, że za tą okazją Kadina (miał mówić Radzyna, czyli Gaudencyusza), brata św. Wojciecha, na tej katedrze osadził, którego metropolii poddał sufraganów: Reinberna kolberskiego, Popona krakuskiego (chciał rzecz krakowskiego), Jana wioteślańskiego (podobno włocławskiego [sic]) biskupów, ale poznański infułat Vernerus poddać się z drugiemi nie chciał, raczej sobie obierając podlegać arcybiskupom magdeburskim"177. W dalszej kolejności jezuicki heraldyk ,zbija” świadectwo Thietmara powołując się na wywody wspominanego już wcześniej kardynała Cesare Baroniusza, zawarte w wysoko w swoim czasie cenionych jego wielotomowych Annales ecclesiastici, wskazując niemniej, że $\mathrm{i}$ ten autor rozmija się w pewnych kwestiach z prawdą (a raczej z tym, co było wówczas uważane za prawdę). Główny nacisk kładzie mianowicie na kwestię dwóch metropolii za czasów wczesnopiastowskich, opowiadając się za tradycją, że ową drugą była właśnie krakowska i przywołując na to rozmaite „dowody” (powołuje się m.in. na znane nam już dywagacje S. Łubieńskiego) ${ }^{178}$. Co się tyczy z kolei zamieszczonego przez K. Niesieckiego wykazu arcybiskupów Gniezna, to wyraźnie zaznacza on, że oparł się tu całkowicie na omawianym już wcześniej dziele S. Damalewicza Series archiepiscoporum Gnesnensium, a w konsekwencji bł. Radzima-Gaudentego znajdujemy tamże na piątym miejscu, jako następcę św. Wojciecha ${ }^{179}$.

również o katalogach biskupów (s. 85-88), natomiast na s. 187-202 o XIX-wiecznym wydaniu owego dzieła).

${ }^{177}$ Korona polska przy złotey wolności starożytnemi wszystkich kathedr, prowincyi y rycerstwa kleynotami, heroicznym męstwem y odwaga, naywyższemi honorami a naypierwey cnota, pobożnościa y światobliwościa ozdobiona, potomnym zaś wiekom na zaszczyt i nieśmiertelna sławe pamiętnych w tey Oyczyźnie synow podana przez X. Kaspra Niesieckiego, Societatis Iesu [...], t. 1, Lwów 1728, s. 15; Herbarz polski Kaspra Niesieckiego S.I., powiększony dodatkami późniejszych autorów, rękopisów, dowodów urzędowych i wydany przez Jana Nepomucena Bobrowicza, t. 1, Lipsk 1839-1846, s. 17.

${ }^{178}$ Korona polska [...] X. Kaspra Niesieckiego, t. 1, s. 15-16 (zob. także s. 27, 30, 34, 40, 56, 78-79, 80, 82); Herbarz polski Kaspra Niesieckiego S. I., t. 1, s. 17-19 (zob. także s. 31, 35, 39, 45, $62,86-87,89,92)$.

${ }^{179}$ Korona polska [...] X. Kaspra Niesieckiego, t. 1, s. 20; Herbarz polski Kaspra Niesieckiego S. I., t. 1, s. 24 nr 5: „Radzyn albo Gaudencyusz, herbu Poraj, umarł 1006”. Na marginesie można tu nadmienić, że o św. Wojciechu, jako arcybiskupie gnieźnieńskim, wspomina nawet historiograf-regionalista Andrzej Komoniecki (ok. 1658-1729) -współczesny K. Niesieckiemu, choć starszy od 
O obu Sławnikowicach XVIII-wieczny heraldyk pisze również w passusie poświęconym herbowi Poraj, gdzie wskazuje też na początki jego obecności w Polsce i na rody nim się posługujące. Tam to czytamy w życiorysie św. Wojciecha, że „Bolesław, książę polski, papieża prosił, aby mu go za arcybiskupa do Gniezna dał, [co działo się] wtenczas, gdy stolica [ta] po Robercie, pierwszym [sic] arcybiskupie, osierociała" (widzimy tu niekonsekwencję Niesieckiego w materii liczby „poprzedników” bł. Radzima-Gaudentego na metropolii gnieźnieńskiej). Wkrótce później jednak przyszły patron polskiej prowincji kościelnej zapragnął udać się „do Prus na nawrócenie pogaństwa do wiary Chrystusowej”, który to plan rychło też urzeczywistnił, przy czym „dwóch z sobą towarzyszów wziął kapłanów na tę drogę, św. Gaudencyusza i drugiego, już z tym umysłem jadąc, iż albo one pogany nawróci, albo wzdy mężną i której dawno pragnął śmierć dla Chrystusa podjąć miał"180. W tym względzie Kasper Niesiecki nie idzie zatem za tradycją przypisującą św. Wojciechowi ustanowienie swego następcy w Gnieźnie, lecz - zgodnie z faktycznym stanem rzeczy - widzi w jego przyrodnim bracie uczestnika tragicznie zakończonej wyprawy misyjnej z roku 997. Tak też w życiorysie bł. Radzima-Gaudentego stwierdza, że dopiero „po śmierci i zamordowaniu św. Wojciecha, za naleganiem Mieczysława [sic], monarchy polskiego, od Grzegorza V papieża na arcybiskupstwo gnieźnieńskie [został] wyniesiony" ${ }^{181}$. O jego wcześniejszych losach pisze zaś, że „w klasztorze brzewnowskim zakonu św. Benedykta professyą uczynił”, potem przebywał wraz z bratem w Rzymie i następnie nieodłącznie towarzyszył mu podczas kolejnych podróży do Czech, Węgier i Polski. Z kolei w późniejszych latach, gdy już zasiadał na stolicy arcybiskupiej w Gnieźnie, ,szczęśliwie trzodą swoją rządził, dla której wizerunkiem był wszelkich cnót, osobliwie pomiarkowania w passjach, rozrzutności na ubogich, łaskawości, życia żadnym zakałem nie zamulonego, trzeźwości [i] żarliwości o honor Boski”"182. K. Niesiecki upatruje w nim również koronatora Bolesława I Chrobrego, w dość oryginalny sposób stwierdzając w odniesienie do samego przebiegu tamtej ceremonii, że to ,cesarz [Otton III] na głowę Bolesława króla przez Gaudencyusza arcybiskupa koronę królewską włożył"183. Nie przeoczył również faktu, że ten to metropolita „Gniezno o niektóre excessa interdyktem obłożył, a potem, gdy zawziętym ta kościelna kara mniej pomogła,

niego o pokolenie - w swej Chronografii albo dziejopisie żywieckim, w którym roczne dzieje spraw przeszłych, starodawnych miasta Żywca i pobliskich jego miejsc znajdują się, a ten z różnych autorów, pism $i$ wiadomości zebrany $i$ wypisany, a w żywa i trwała pamięć miastu żywieckiemu, jako ojczyźnie swojej miłej, ofiarowany roku Pańskiego 1704, przez sław[et]nego Andrzeja Komonieckiego, wójta natenczas żywieckiego, manu propria, wyd. S. Grodziski i I. Dwornicka, Żywiec 1987, s. 437 (w zapisce pod rokiem 1713).

${ }^{180}$ Korona polska [...] X. Kaspra Niesieckiego, t. 3, Lwów 1740, s. 663; Herbarz polski Kaspra Niesieckiego S. I., t. 7, Lipsk 1841, s. 402.

${ }^{181}$ Korona polska [...] X. Kaspra Niesieckiego, t. 3, s. 665; Herbarz polski Kaspra Niesieckiego S. I., t. 7, s. 405.

${ }^{182}$ Korona polska [...] X. Kaspra Niesieckiego, t. 3, s. 665; Herbarz polski Kaspra Niesieckiego S. I., t. 7, s. 405 .

${ }^{183}$ Korona polska [...] X. Kaspra Niesieckiego, t. 3, s. 665; Herbarz polski Kaspra Niesieckiego S. I., t. 7, s. 404 (także s. 405). 
prorockim duchem opowiedział tę klęskę, którą wkrótce na sobie poniosło to miasto, gdy go Brzetysław, książę czeski, i Sewerus, biskup Pragi, złupili”184. Śmierć Gaudentego kładzie - w ślad za poprzednikami - na rok 1006, podobnie też opowiada się za opinią, że podczas najazdu z roku 1038 jego ciało uwiezione zostało do Czech, podczas gdy relikwie świętowojciechowe zostały „utajone w podłym miejscu, gdzieś od podejrzenia dalekim”, podejmując przy tym wyraźną polemikę $\mathrm{z}$ autorami wyrażającymi przeciwne opinie (tu również znana nam już opowieść o rozmowie biskupa Marcina Kromera z cesarzem Ferdynandem I, z którego wszakże jezuicki heraldyk uczynił Ferdynanda III) ${ }^{185}$. Wreszcie na sam koniec żywotu bł. Radzima-Gaudentego przytoczona została kilkakrotnie tu przywoływana parafraza opowieści z kroniki Kosmasa o cudownym uwolnieniu więźnia, który i u Niesieckiego zwie się Tomaszem (z dookreśleniem „Pragensis”), w karcerze przebywać miał lat siedem, cud się wydarzył 7 VI 1071 - po uprzednich gorących modłach, świadomie zanoszonych przez nieszczęśnika do niegdysiejszego arcybiskupa Gniezna. O dalszych zaś losach uwolnionego młodzieńca (i on bowiem uważa go za „młodzieńca o pewny kryminał, na siebie włożony, do więzienia wtrąconego") tenże autor pisze, że „wyszedłszy [z karceru], niewinność swoją urzędownie jawnymi dowodami wyprowadził, [a] wkrótce między kanoników kapituły praskiej policzony, dalej dziekanem, na koniec biskupem praskim został [i] póki żył, wdzięczny [pozostał] tej łaski Gaudencyusowi"186.

W obecnym przeglądzie warto zwrócić uwagę również na wydane w roku 1740 w Lipsku dzieło Historia Polona a Lecho ad Augusti II. mortem autorstwa gdańszczanina Gotfryda Lengnicha (1689-1774) ${ }^{187}$. Pomimo swych niemieckich korzeni (dopiero w wieku 13 lat rozpoczął naukę języka polskiego) ów gdański syndyk, a zarazem profesor i inspektor Gimnazjum Akademickiego w Gdańsku, wniósł - analogicznie, jak tak samo związany z Pomorzem Nadwiślańskim Jerzy Schwengel - istotny wkład do rodzimego dziejopisarstwa. Tak też w rzeczonym kompendium dziejów Polski wykazał się on większą jeszcze ostrożnością, aniżeli współczesny mu przeor kartuzji kaszubskiej, przy Mieszku I w ogóle nie wspominając o założeniu jakoby już wówczas pierwszych polskich biskupstw ${ }^{188}$. Że zaś nie było to li tylko przypadkowe pominięcie, lecz w pełni świadomy zabieg, dowodzą wywody w kolejnym z rozdziałów publikacji G. Lengnicha, poświęconym

${ }^{184}$ Korona polska [...] X. Kaspra Niesieckiego, t. 3, s. 665; Herbarz polski Kaspra Niesieckiego S. I., t. 7, s. 405.

${ }^{185}$ Korona polska [...] X. Kaspra Niesieckiego, t. 3, s. 666; Herbarz polski Kaspra Niesieckiego S. I., t. 7, s. 405-406.

${ }^{186}$ Korona polska [...] X. Kaspra Niesieckiego, t. 3, s. 666-667; Herbarz polski Kaspra Niesieckiego S. I., t. 7, s. 406-407.

${ }^{187}$ Gotfridi Lengnich Historia Polona a Lecho ad Augusti II. mortem, Lipsiae 1740. O autorze zob. m.in. Polska - dzieje i rzeczy jej rozpatrywane przez Joachima Lelewela, t. 1, $25 \mathrm{nr}$ CXIV; Estreicher, Bibliografia polska, t. 21, Kraków 1906, s. 167-174; S. Salmonowicz, Lengnich Gotfryd (1689-1774), gdański prawnik i historyk, PSB, t. 17, s. 46-49; HNP, t. 6, s. 352-353; Stownik historyków polskich, s. 294; Stownik biograficzny Pomorza Nadwiślańskiego, t. 3, red. Z. Nowak, Gdańsk 1997, s. 45-47 (E. Cieślak); A. F. Grabski, Zarys historii historiografii, s. 70-72; Dawni pisarze polscy, t. 2, s. 330-331 (E. Aleksandrowicz).

${ }^{188}$ Gotfridi Lengnich Historia Polona, s. 2 § IV. 
Bolesławowi I Chrobremu. Powołując się mianowicie na Thietmara, wspomina on tam o przybyciu w roku 1000 do Gniezna cesarza Ottona III i w sposób jednoznaczny, nie pozostawiający pola dla jakiejś alternatywnej interpretacji, stwierdza: „eodem tempore archiepiscopatus Gnensnensis et episcopatus Cracoviensis cum aliis instituti [sunt]"189. W tym kontekście przywołuje zresztą nie tylko dzieło merseburskiego biskupa, ale też wydaną już wówczas drukiem (w tomie I zbioru Silesiacarum rerum scriptores F.W. Sommersberga) XIV-wieczną Kronike ksiażat polskich, gdzie w odniesieniu do pierwszego koronowanego władcy Polski mowa jest, iż „hic Boleslaus Chabri [...] ecclesias multas construxit, episcopos ordinavit, metropolim Gneznensem instituit et suffraganeos plures sibi subiecit, certis terrarum et bonorum terminis cuiuslibet pro sustentacione congrua deputatis" ${ }^{190}$. Ponadto wskazuje w innych miejscach rzeczonego rozdziału także m.in. na Annales Hildesheimenses, Kosmasa, mistrza Wincentego (Kadłubka) tudzież wspomiany wyżej zbiór Poloniae historiae corpus. Tym samym mamy tu do czynienia z publikacją, która nawet z dzisiejszej perspektywy zasługiwałaby na miano naukowej.

Choć przywołane wcześniej dzieła K. Niesieckiego, F. Rzepnickiego i F. Jaroszewicza głęboko tkwią jeszcze w tradycjach barokowego piśmiennictwa (czy to hagiograficznego, czy też żywotów sławnych postaci), to jednak dają w nich o sobie znać pewne, póki co nieśmiałe jeszcze „przebłyski” właściwego epoce oświecenia krytycyzmu (u jednego jest to kwestia udziału Radzima-Gaudentego w wyprawie św. Wojciecha do Prus, u innego sprawa autentyczności znajdujących się w Pradze relikwii). Natomiast o właściwym przełomie w interesującej nas tu problematyce zwykło się mówić w odniesieniu do dziejopisarstwa staropolskiego dopiero w kontekście wydawanej w kilkanaście lat później wielotomowej Historii narodu polskiego od początku chrześcijaństwa autorstwa słynnego historyka i poety Adama Naruszewicza (1733-1796), ówcześnie już biskupa-koadiutora smoleńskiego. Nad dziełem tym pracował on co najmniej od połowy lat siedemdziesiątych XVIII w., gromadząc olbrzymi zbiór wypisów źródłowych do dziejów Polski, a nie mniej zdobywając gruntowne rozeznanie w materii dotychczasowego rodzimego piśmiennictwa historiograficznego, skonfrontowanego również $\mathrm{w}$ jakiejś mierze z piśmiennictwem ościennych krajów. Mając tedy tak solidny fundament tudzież świadomość potrzeby krytycznego spojrzenia na wiele ugruntowanych w dotychczasowej historiografii twierdzeń, A. Naruszewicz nie zdecydował się jednak przyjąć za prawdę to, przed czym wzdragali się również jego poprzednicy, a mianowicie, że ukonstytuowanie metropolii gnieźnieńskiej łączyć należy ze zjazdem w Gnieźnie roku 1000. W wydanym w r. 1780 w Warszawie tomie drugim Historii narodu polskiego czytamy jedynie, że jest to początek rządów pasterskich Radzima-Gaudentego, o którym autor ów wspomina zresztą po raz pierwszy w związku z poprawnie datowaną przezeń na rok 997 wyprawą

${ }^{189}$ Tamże, s. $3 \S \mathrm{V}$.

${ }^{190}$ Silesiacarum rerum scriptores [...], ed. F. W. de Sommersberg, t. 1, Lipsiae 1729, s. 17 (De Boleslao Primo Chabri dicto). Tamże, na s. 18, obszerniej o zjeździe gnieźnieńskim, podczas którego to "Boleslaus per imperatorem regio dyademate coronatur". Zob. także Kronika książat polskich, wyd. Z. Węclewski, MPH, t. 3, s. 438-440. 
misyjną św. Wojciech do Prus, jako o jej uczestniku (a zatem na przekór większości spośród staropolskich historiografów) ${ }^{191}$. Przy opisie owych doniosłych wydarzeń, związanych z przybyciem w roku 1000 do Gniezna cesarza Ottona III, Naruszewicz stwierdza wprawdzie, że wówczas to „kreował [on] arcybiskupem Radzyna, czyli Gaudencyusza, mnicha, towarzysza św. Wojciecha, a trzech innych polskich biskupów [...] pod jego władzę poddał" 192 , a także powołuje się na Annales Hildesheimenses i zwraca uwagę na ową tak istotną zapiskę, z której dowiadujemy się, że w rzeczonym roku cesarz ,episcopia VII disposuit” ${ }^{193}$, mylnie niemniej uważa za sufragana metropolity Gniezna jakoby już w tamtym czasie - obok biskupów Krakowa i Kołobrzegu - także biskupa Włocławka, utrzymując, że „Wrocław tu nie służy, jako chcą drudzy, ponieważ do Wrocławia biskupstwo smogorzewskie, a potem byczyńskie, dopiero pod Kazimierzem [Odnowicielem] było przeniesione" 194 .

Owa wzmianka o biskupstwach kujawskim i smogorzowskim przy przedstawieniu wydarzeń roku 1000 nie pozostawia wątpliwości, że A. Naruszewicz opowiedział się jednak po stronie tych autorów, którzy żywili przeświadczenie o wcześniejszym ukonstytuowaniu rozbudowanej organizacji diecezjalnej na ziemiach polskich. W materii tej nie jesteśmy zresztą skazani na wnioskowanie jedynie z pośrednich przesłanek, jako że w jednym z poprzednich rozdziałów, odnoszącym się do panowania Mieszka I, autor Historii narodu polskiego stwierdza wprost, że ten to władca ,ufundował, jak powszechne niesie mniemanie, dziewięć kościołów [katedralnych], po różnych państwa swojego miastach, [mianowicie] w Gnieźnie, w Krakowie, w Poznaniu, w Kruświcy, skąd potem do Włocławka pod imieniem katedry kujawskiej był przeniesiony, w Smogrze, który także naprzód do Byczyny w powiecie bregeńskim na Szląsku, potem dla okazałości miasta do Wrocławia przeniósł się, w Płocku czyli Mazowszu, w Chełmie [sic], w Kamieniu i Lubaszu. [...] Na urządzenie zaś rozpoczętego od Mieczysława dzieła, przysłany był w charakterze legata od Jana XIII papieża Idzi kardynał, biskup tuskulański”. ${ }^{195}$ Wątek ów znajduje też rozwinięcie w kolejnym rozdziale, gdzie czytamy, iż jako „pierwsi siedzieć mieli na stolicach arcybiskupich: w Gnieźnie Willibaldus, w Krakowie Prochor, a na biskupich katedrach: w Poznaniu Jordan, w Smogrowie Gotfryd, w Kruświcy Lucydus, w Płocku Angelotus, w Chełmży Oktawian, w Kaminie Julian, w Lubuszu Hiacynt"196. W tym zatem kontekście

${ }^{191}$ A. Naruszewicz, Historya narodu polskiego od początku chrześcijaństwa, t. 2, Warszawa 1780, s. 78. Zob. także XIX-wieczne wydanie: Historya narodu polskiego przez Adama Naruszewicza, biskupa łuckiego, t. 1, wyd. K. J. Turowski, Kraków 1859, s. 89-90.

192 Naruszewicz, Historya narodu polskiego, t. 2, s. 88-89; Historia narodu polskiego przez Adama Naruszewicza, t. 1, s. 98.

${ }^{193}$ Naruszewicz, Historya narodu polskiego, t. 2, s. 89 przyp. (a); Historia narodu polskiego przez Adama Naruszewicza, t. 1, s. 98 przyp. 3.

${ }^{194}$ Naruszewicz, Historya narodu polskiego, t. 2, s. 89 przyp. (z); Historia narodu polskiego przez Adama Naruszewicza, t. 1, s. 98 przyp. 4.

${ }^{195}$ Naruszewicz, Historya narodu polskiego, t. 2, s. 33-34; Historia narodu polskiego przez Adama Naruszewicza, t. 1, s. 58 (rozdz. XVI).

${ }^{196}$ Naruszewicz, Historya narodu polskiego, t. 2, s. 35-36; Historia narodu polskiego przez Adama Naruszewicza, t. 1, s. 59 (rozdz. XVII). 
doprawdy trudno w sposób jednoznaczny ocenić, jak A. Naruszewicz rozumiał $\mathrm{i}$ interpretował zaczerpnięte przezeń z Thietmara informacje. Co się tyczy bł. Radzima-Gaudentego to najwyraźniej ów XVIII-wieczny dziejopis uznał, że rok 1000 stanowi wprawdzie początek jego pontyfikatu w Kościele gnieźnieńskim, tudzież że swe wyniesienia zawdzięczał on cesarzowi Ottonowi, nie był to jednak wedle Naruszewicza zarazem początek istnienia stolicy metropolitalnej w Gnieźnie, bowiem we wcześniejszych partiach swego dzieła jednoznacznie odpowiedział się za jej powstaniem jeszcze za czasów Mieszka I. Skoro jednak również pozostałe, wyliczone uprzednio przezeń diecezje polskie miały zostać powołane do istnienia od razu w najbliższym czasie po chrzcie pierwszego historycznego władcy Polski, to co w takim razie miało by niby oznaczać owo podporządkowanie zwierzchności Radzima-Gaudentego, jako arcybiskupa Gniezna, trzech innych biskupów polskich w roku 1000? Mając na uwadze rzekome istnienie już wcześniej dwóch prowincji kościelnych w państwie wczesnopiastowskim, mianowicie gnieźnieńskiej i krakowskiej, można by domyślać sie, że owi trzej hierarchowie do tamtego momentu podlegali zwierzchności metropolitalnej arcybiskupa Krakowa, natomiast odtąd rozciągać się miała nad nimi jurysdykcja drugiego z arcybiskupów, czyli gnieźnieńskiego. Takie ujęcie problemu stanowiłoby bodaj jedyną dającą jakiś logiczny sens próbę pogodzenia zacytowanych powyżej fragmentów Historii narodu polskiego. Niestety, wprowadzenie jakiegokolwiek iunctim nie jest tu jednak możliwe, jako że Naruszewicz - na co uprzednio wskazano - przytacza w ślad za Thietmarem imiona owych trzech biskupów tudzież podaje nazwy powierzonych im diecezji („,kolberska w Pomeranii, władysławska [miast wroctawskiej] i krakowska"), dając tym samym dowód, że najwyraźniej zdążył już przy kreśleniu owego passusu zapomnieć, co sam na temat pierwocin organizacji hierarchicznej Kościoła polskiego pisał w odniesieniu do panowania Mieszka I. Nie sposób bowiem zakładać, że według niego rok 1000 przyniósł zarazem kres istnieniu stolicy metropolitalnej w Krakowie i jej podporządkowanie na przyszłość zwierzchnictwu arcybiskupów gnieźnieńskich. Wszak o tak ważnej zmianie w sytuacji kościelnej ziem polskich A. Naruszewicz z pewnością by nie omieszkał wspomnieć na kartach swego dzieła, gdyby faktycznie uważał, że miała ona miejsce, stąd milczenia w owej materii nie sposób interpretować na jego korzyść ${ }^{197}$.

Widzimy zatem, że i ten historyk ostatecznie jednak się pogubił w swoich wywodach w interesującej nas problematyce, stąd dopatrywanie się w Historii narodu polskiego - przynajmniej w owym względzie - przełomu historiograficznego,

${ }^{197}$ Jak żywe było wówczas przeświadczenie o niegdysiejszej godności arcybiskupiej pasterzy Kościoła krakowskiego dowodzić może ten fakt, że nawet w oficjalnej relacji dla Stolicy Apostolskiej o stanie diecezji krakowskiej, z roku 1731, jej ówczesny ordynariusz, biskup Konstanty Felicjan Szaniawski, w odniesieniu do świątyni katedralnej na Wawelu stwierdził: „Ecclesia haec mea cathedralis omnium in Regno antiquissima [est] et olim archiepiscopali dignitate insignita". - Relacje o stanie diecezji krakowskiej 1615-1765, wyd. W. Müller, Lublin 1978, s. 120 (zob. również: tamże, s. 132-133, gdzie mowa o racjonale biskupów krakowskich, używanym ,in memoriam archiepiscopali olim dignitatis episcopi loci”). Por. wyżej świadectwo przywołane w przyp. 36. 
wydaje się zdecydowanie na wyrost ${ }^{198}$. Nie ulega natomiast wątpliwości, że dzieło Adama Naruszewicza stało się na pewien czas nowym „punktem odniesienia” dla kolejnych generacji rodzimych historyków, którym wszakże przyszło tworzyć w zupełnie odmiennych realiach dziejowych, już po upadku Rzeczypospolitej Obojga Narodów, w ślad za czym dokonały się też daleko idące przekształcenia w organizacji diecezjalnej Kościoła katolickiego na ziemiach polskich, zacierające ów noszący jeszcze znamię pierwotnych regulacji sprzed ośmiu wieków dotychczasowy obraz. Biskup Naruszewicz miał zresztą to nieszczęście dożyć kresu polskiej państwowości, której minione losy opisywał, przy czym owe tragiczne okoliczności ponoć przyspieszyły jego zgon (nastąpił już w roku 1796). Nie zmienia to faktu, że - wedle słów Kazimierz Chodynickiego - na zawsze pozostał on tym, który „w historiografii polskiej zdobył sobie stanowisko przełomowe nie tylko przez swoją działalność dziejopisarską, ale i przez to, że on pierwszy w Polsce zdawał sobie jasno sprawę z zadań i metody historii" ${ }^{199}$. Co się zaś tyczy interesującej nas obecnie problematyki pierwocin organizacji diecezjalnej w Polsce wczesnopiastowskiej oraz umiejscowienia w tym kontekście osoby bł. RadzimaGaudentego, to rzeczywisty przełom w rodzimym piśmiennictwie historycznym łączyć należy z urodzonym dziesięć lat przez śmiercią Naruszewicza Joachimem Lelewelem (1786-1861), który nie powtórzył już błędów swoich poprzedników, lecz z niezwykłą erudycją zbił (m.in. w wielotomowej panoramie Polska wieków średnich) występujące w owej materii u staropolskich dziejopisów fałsze ${ }^{200}$. Jego twórczość wykracza już wszakże poza ramy chronologiczne przyjęte dla obecnej prezentacji ${ }^{201}$.

${ }^{198}$ Dla kompletności dodajmy, że A. Naruszewicz nie pominął także informacji o zabraniu w r. 1038 z Gniezna podczas najazdu czeskiego ciała bł. Radzima-Gaudentego, „podłożonego” w miejsce ciała św. Wojciecha. Naruszewicz, Historya narodu polskiego, t. 2, s. 301; Historia narodu polskiego przez Adama Naruszewicza, t. 1, s. 266.

${ }^{199}$ K. Chodynicki, Poglądy na zadania historii w epoce Stanisława Augusta, Warszawa 1915, s. 35 i nn. Zob. również A. F. Grabski, Myśl historyczna polskiego oświecenia, Warszawa 1976, s. 160-185; M. Deszczyńska, «Historia sacra» i dzieje narodowe. Refleksja historyczna z lat 1795-1830 nad rola religii i Kościoła w przeszłości Polski, Warszawa 2003, s. 34 nn. Z nowszych publikacji o Adamie Naruszewiczu por. J. Platt, Adam Naruszewicz (1733-1796), w: Pisarze polskiego oświecenia, t. 1, red. T. Kostkiewiczowa i Z. Goliński, Warszawa 1992, s. 309-350; Adam Naruszewicz i historiografia oświecenia, red. K. Bartkiewicz, Zielona Góra 1998 (m.in. na s. 125-136: V. Julkowska, Naruszewiczowska koncepcja narracji historycznej, czyli o sztuce pisania his-torii); W. Zarzycki, Biskup Adam Naruszewicz - luminarz polskiego oświecenia, Lublin 1999; Prokop, Sylwetki biskupów tuckich, s. 165-168.

${ }^{200}$ M.in. Polska - dzieje i rzeczy jej rozpatrywane przez Joachima Lelewela, t. 1, Poznań 1858, s. 87, 413 (gdzie Abecadłowy rozkład znamienitych ludzi); Polska wieków średnich, czyli Joachima Lelewela $w$ dziejach narodowych polskich postrzeżenia, t. 2, Poznań 1847, s. 26 nn, 59 nn; i in.

${ }^{201}$ Zob. ostatnio A. Wierzbicki, Historiografia polska doby romantyzmu, Wrocław 1999, wg indeksu; także Deszczyńska, «Historia sacra» i dzieje narodowe, wg indeksu. 
VI.

Aż do najnowszych czasów rozpoczynano, idąc za ojcem dziejopisarzów naszych, Długoszem, szereg arcybiskupów gnieźnieńskich od Willihalma albo Wilibalda, który w roku 966 miał objąć rządy arcybiskupstwa. Pierwszy z nowszych historyków naszych, Naruszewicz, rozpoczyna tenże szereg od Radzyna, brata św. Wojciecha, w roku 1000, w którym arcybiskupstwo gnieźnieńskie przez papieża Sylwestra II w porozumieniu z cesarzem Ottonem III i Bolesławem Chrobrym ustanowione zostało, lecz czy to lękając się obalić podtrzymywany przez kilka wieków porządek gnieźnieńskich arcypasterzów, czy też nie wgłębiając się dostatecznie we współczesnego założeniu arcybiskupstwa gnieźnieńskiego kronikarza Dytmara, późniejszego biskupa merseburskiego, utrzymuje błędnie, że w roku 1000 istniejące już pop\rzednio biskupstwo gnieźnieńskie do godności arcybiskupstwa i metropolii polskiej zostało wyniesione" - pisał w roku 1881, nie do końca wszakże zgodnie z prawdą, Jan Korytkowski w przedmowie do swego Katalogu arcybiskupów gnieźnieńskich, opublikowanego na łamach „Rocznika Towarzystwa Przyjaciół Nauk Poznańskiego”, dodając w konkluzji: „Późniejsi pisarze nasi i zagraniczni kwestię dotyczącą założenia biskupstw w Polsce, a mianowicie biskupstwa poznańskiego i arcybiskupstwa gnieźnieńskiego, gruntownie i wyczerpująco wyjaśnili [...]. Również i zagadka przyswajania sobie przez siedem wieków trzech zmyślonych arcybiskupów [...], pożyczonych z katalogu arcybiskupów mogunckich, i wtrącenia pomiędzy nich a Radzyna, pierwszego rzeczywistego arcybiskupa gnieźnieńskiego, św. Wojciecha, ostateczne znalazła wyjaśnienie" 202 . Owi przywołani przez XIX-wiecznego historyka Kościoła badacze polscy, na których publikacje wskazał też w przypisie, to właśnie Joachim Lelewel oraz Ksawery Liske, a obok nich bliżej nieznany bibliografom niejaki Leporowski, który miał być autorem rozprawy De primis episcopatibus in Polonia conditis (Würzburg 1874)203. Liczniejsze jest natomiast grono cytowanych przezeń uczonych niemieckich (Christian Gottlieb Friese, Richard Roepell, Nathan Friedrich Kantz, Joseph Ignatz Ritter), a przede wszystkim ich publikacje są wcześniejszej daty - niektóre jeszcze z XVIII w. (Kantz, Friese). Tak też faktem jest, że definitywne wykazanie nieprawdziwości pokutującego przez stulecia w polskim piśmiennictwie historiograficznym twierdzenia o powstaniu rozwiniętej organizacji diecezjalnej w Polsce od razu w momencie chrztu Mieszka I, zawdzięczamy w pierwszej kolejności właśnie zgłębiającym problematykę dziejów ziem polskich erudytom rodem z Niemiec. Pozostawało to w związku z okolicznością, że ich wizji przeszłości nie kształtowała spuścizna piśmiennicza Długosza, Miechowity czy Kromera, jak to miało miejsce w przypadku polskich autorów, którzy właśnie od tych dzieł rozpoczynali swe poszukiwania, przyjmując zawarty

${ }^{202}$ J. Korytkowski, Katalog arcybiskupów gnieźnieńskich, „Roczniki Towarzystwa Przyjaciół Nauk Poznańskiego", 11 (1881) s. 3-5. Zob. tamże, na s. 85-90: Zestawienie powyższego katalogu z porządkiem co do następstwa i czasu podanym $w$ żywotach arcybiskupów gnieźnieńskich Dlugosza, Damalewicza, Bużeńskiego tudzież dwóch katalogów tychże arcybiskupów ogłoszonych $w$, Monumenta Poloniae Historica” tomie III.

${ }^{203}$ Por. Semkowicz, Krytyczny rozbiór «Dziejów polskich», s. 78. 
W nich obraz wydarzeń z minionych stuleci za stały punkt odniesienia - sui generis nieruchomy firmament, o którego podważaniu zgoła nikt poważnie nie myślał. W tej sytuacji nawet gdy już sięgali po świadectwa zawarte u Thietmara czy też we współczesnych zabytkach rocznikarstwa, nie wahali się uznać je za niewiarygodne, co w sposób szczególnie jaskrawy, a do pewnego stopnia wręcz kuriozalny, uwidoczniło się w dywagacjach Stanisława Łubieńskiego. Natomiast uczeni niemieccy, dla których Długosz i późniejsi dziejopisarze staropolscy w żadnym wypadku nie stanowili „lektury obowiązkowej”, od której rozpoczynało się studia nad dawnymi wiekami, kiedy już na dalszym etapie swych prac faktycznie do ich dzieł sięgali, nie mieli raczej wątpliwości (znając przekazy źródłowe kręgu niemieckiego oraz rodzimą tradycję historiograficzną), które z tych sprzecznych w swej wymowie świadectw uznać za prawdziwe. W tej swego rodzaju ,konfrontacji" staropolskie piśmiennictwo historyczne - w świetle wyników późniejszych badań naukowych - okazało się stroną ,przegraną”, na czym zaważyły wszakże przesłanki natury obiektywnej.

Prześledzony w obecnym studium casus bł. Radzima-Gaudentego ${ }^{204}$ pokazuje, jak nieopatrzne opowiedzenie się za bardziej wprawdzie schlebiającą dumie narodowej, wszakże nie mającą wiarogodnych podstaw wizją faktów z przeszłości, koniec końców doprowadzić musi w ślepy zaułek. W efekcie autentyczny trud poznawczy i wysiłek intelektualny wielu dziejopisów okazał się niemal całkowicie jałowy, bo z ich konstrukcji (czy też rekonstrukcji przeszłości) de facto nic się nie ostało i w konsekwencji nikt też w owej materii na ich dzieła aktualnie się nie powołuje, czego z pewnością ani nie przewidywali, przystępując do pracy, ani tym bardziej takiego obrotu rzeczy nie pragnęli. To wszakże, co z dzisiejszej perspektywy najbardziej może zaskakiwać, jest owa zgoła zdumiewająca żywotność tegoż «mitu historiograficznego», który nie tylko, że był podtrzymywany (i zarazem sukcesywnie „ubogacany” w swej warstwie pseudo-faktograficznej) przez kolejne generacje rodzimych dziejopisów, ale w zasadzie aż po schyłek XVIII w. nie znalazł adwersarzy na polskim gruncie (wyjątki były w tym względzie nieliczne i dotyczyły co najwyżej wybranych kwestii, jak w przypadku podyktowanego zresztą przede wszystkim względami ambicjonalnymi zanegowania przez A. Olszowskiego istnienia za czasów Polski wczesnopiastowskiej arcybiskupstwa krakowskiego). W tych okolicznościach, w dobie postępującej krytyki naukowej w kolejnym stuleciu rodzimym historykom przyszło poniekąd ze wstydem wycofać się z „uświęconego" tradycją stanowiska swych poprzedników i przyznać rację nauce niemieckiej, co w rzeczywistości niewoli narodowej doby porozbiorowej musiało przyjść tym bardziej niełatwo i mieć do pewnego stopnia gorzki posmak. Nie dziwi zatem, że byli też tacy, którzy trwali przy tamtej nieprawdziwej wizji, jak świadczyć o tym może chociażby wysoko cenione w swoim czasie i nawet dziś jeszcze niekiedy przywoływane przez badaczy kilkutomowe dzieło

${ }^{204}$ Przy szerzej zakrojnych poszukiwaniach bibliograficznych niewątpliwie można by wskazać jeszcze na pewną liczbę pomniejszych dzieł drukowanych z epoki staropolskiej, w których wspomniana została osoba intersującego nas hierarchy, jak ma to miejsce chociażby w przypadku Kalendarza polskiego i ruskiego na rok Pański 1746 od narodzenia Chrystusowego (również na rok 1752) Stanisława Józefa Duńczewskiego (1701-1767), profesora Akademii Zamojskiej. 
Starożytna Polska Michała Balińskiego i Tymoteusza Lipińskiego, którzy (w tomie I z r. 1843) w opisie Gniezna informują czytelnika, że to Mieszko I „wystawił [tam] kościół katedralny pod tytułem Wniebowzięcia Panny Maryi, którego pierwszym pasterzem był Wilibald", zaś nieco dalej dodają, iż w roku 1000 cesarz Otto III „wyniósł katedrę gnieźnieńską na metropolię całego Królestwa i Radzyn, czyli Gaudencyusz, brat św. Wojciecha, został pierwszym arcybiskupem" (jest to zatem właśnie owa nowa interpretacja wydarzeń z r. 1000, później przypisana bezpodstawnie przez Korytkowskiego Naruszewiczowi ${ }^{205}$. Dziś do tamtej koncepcji W zasadzie nikt nie nawiązuje ${ }^{206}$, trudno niemniej nie skonstatować, że jakkolwiek w tym akurat konkretnym przypadku ów powtarzany przez stulecia fałsz został już stosunkowo dawno „zdemaskowany” i wyrugowany z obiegu naukowego, to jednak we współczesnym piśmiennictwie historycznym wskazać można na niejedną jeszcze sugestywną i plastycznie zaprezentowaną wizję wybranych aspektów przeszłości, która wszakże nie ma wiele wspólnego z prawdą ${ }^{207}$.

${ }^{205}$ Starożytna Polska pod względem historycznym, jeograficznym i statystycznym opisana przez Michała Balińskiego i Tymoteusza Lipińskiego, t. 1, Warszawa 1843, s. 181-182. Tam również mowa o najeździe czeskim z roku 1038 i uwiezieniu przez Czechów „Zwłok arcybiskupa Radzyna w srebrnej trumnie złożonych" (s. 182). Por. także K. Sienkiewicz, Skarbiec historii polskiej, t. 1, Paryż 1839, s. 238 (gdzie jako pierwsi w poczcie arcybiskupów gnieźnieńskich wyliczeni są - kolejno - Willibald, Hatto, Robert, Wojciech i na piątym miejscu Radzim).

${ }^{206}$ Owo zastrzeżenie „w zasadzie” jest poniekąd usprawiedliwione, bowiem chociażby w wydanym na milenium roku 2000 Poczcie biskupów wrocławskich autorstwa J. Patera znajdujemy na początku przejęte z katalogu Jana Długosza imiona hierarchów, poczynając od ustanowionego jakoby jeszcze w roku 966 Gotfryda, których wprawdzie ujęto w osobny rozdział, opatrzony nagłówkiem Biskupi legendarni, lecz mimo to każdemu z nich przydano biogram, o czterech spośród sześciu owych hierarchów pisząc też, że to postać „prawdopodobnie legendarna”. - J. Pater, Poczet biskupów wrocławskich, Wrocław 2000, s. 7-8. Por. T. Jurek, Ryczyn biskupi. Studium z dziejów Kościoła polskiego w XI wieku, „Roczniki Historyczne”, 60 (1994) s. 21-64.

${ }^{207}$ Pierwszy z brzegu, niemniej szczególnie eksponowany przykład, to rzekome „przeniesienie" stolicy z Krakowa do Warszawy w r. 1596, którego czterechsetną rocznicę celebrowano uroczyście przed piętnastu laty. - Zob. J. Małecki, Kiedy i dlaczego Kraków przestał być stolica Polski, „Rocznik Krakowski”, 44 (1973) s. 21-36. 


\title{
BLESSED ARCHBISHOP RADZIM-GAUDENTY AND THE ISSUE OF THE ORIGINS OF THE METROPOLIS OF GNIEZNO IN THE OLD POLISH HIS- TORIOGRAPHY
}

\begin{abstract}
Summary
Archbishop Radzim-Gaudenty, half-brother of St. Adalbert, was the first Metropolitan of the Diocese of Gniezno. Little is known about his life and work, even the date of his death is uncertain. This lack of information is connected with scarce historical sources. In this article the author reviewed the Old Polish historical sources which reveal the information about Archbishop RadzimGaudenty. The oldest Polish chronicles, among others, Gallus Anonymus or Wincenty Kadłubek, are silent on the matter of this hierarch. Only in the $15^{\text {th }}$ century Jan Długosz in his works published a lot of information about him. In the $16^{\text {th }}$ century the following authors wrote about the Metropolitan: Maciej Karpiga from Miechów, Marcin Kromer, Stanisław Orzechowski, Jan Herburt, Maciej Stryjkowski, Marcin Bielski, Piotr Skarga, Bartosz Paprocki. In the $17^{\text {th }}$ century the history of the Archbishop was presented by Szymon Staropolski, Szymon Okolski, Stanisław Łubieński, Stefan Damalewicz, Piotr Hiacynt Pruszcz, Stanisław Sczygielski vel Szczygielski, Andrzej Olszowski and Stanisław Bużeński. In the $18^{\text {th }}$ century the issues connected with the life of the Bishop can be found in the works of Jerzy Schwengl, Florian Jacek Jaroszewicz, Franciszek Rzepnicki, Kasper Niesiecki, Gotfryd Lengnich and Adam Naruszewicz.
\end{abstract}

Translated by Aneta Kiper 